\title{
The Impact of an Evidence-Based Multi-component Intervention on Colorectal Cancer Screening in Primary Care at a Healthcare System
}

\author{
Ahnnya Slaughter \\ University of St. Augustine for Health Sciences, a.slaughter1@usa.edu \\ DOI: https://doi.org/10.46409/sr.ELIK2330
}

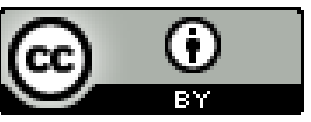

This work is licensed under a Creative Commons Attribution 4.0 License.

Follow this and additional works at: https://soar.usa.edu/scholprojects

Part of the Family Practice Nursing Commons, and the Primary Care Commons

\section{Recommended Citation}

Slaughter, A. (2021). The Impact of an Evidence-Based Multi-component Intervention on Colorectal Cancer Screening in Primary Care at a Healthcare System. [Doctoral project, University of St Augustine for Health Sciences]. SOAR @ USA: Student Scholarly Projects Collection. https://doi.org/10.46409/ sr.ELIK2330

This Scholarly Project is brought to you for free and open access by the Student Research at SOAR @ USA. It has been accepted for inclusion in Student Scholarly Projects by an authorized administrator of SOAR @ USA. For more information, please contact soar@usa.edu, erobinson@usa.edu. 
The Impact of an Evidence-Based Multi-component Intervention on Colorectal Cancer Screening in Primary Care at a Healthcare System

\author{
Ahnnya Slaughter, MSN, BSN, CNS-BC, RN-C \\ School of Nursing, University of St. Augustine for Health Sciences \\ This Manuscript Partially Fulfills the Requirements for the \\ Doctor of Nursing Practice Program and is Approved by: \\ Theresa Pape, PhD, RN, CNOR-E, CNE \\ Marla Weiss, DNP, FNP-C
}

July 26, 2021 


\begin{abstract}
Practice Problem: Colorectal cancer is the second leading cause of cancer death in the United States; many of the deaths are preventable with early detection. Adherence rates for colorectal cancer screening with fecal immunochemical test kits (FIT) was below the national benchmark at this facility.
\end{abstract}

PICOT: The PICOT question that guided this project was: Among veterans 50 - 75 years old requiring average risk colorectal cancer screening (CRCS) seen in primary care at a veterans affairs healthcare system facility (P), how does the use of a multi-component intervention (I), compared to the usual care $(\mathrm{C})$, affect the number of patients completing CRCS (O) over a period of 12 weeks $(\mathrm{T})$ ?

Evidence: Review of high-quality studies suggested a multi-component approach, including increasing provider awareness and increasing patient education and outreach, as the most effective approach to increase colorectal screening compliance.

Intervention: The multi-component intervention included a standardized CRCS nurse navigation process through standard work which included the teach-back method, patient outreach, and provider feedback.

Outcome: There were clinically significant improvements in adherence with returned FIT kits, follow up for abnormal FIT kits, and statistically significant improvements with nursing documentation of patient teaching. The number of patients overdue for CRCS decreased. Conclusion: The multi-component CRCS screening intervention demonstrated significant improvements in the intervention clinics which is consistent with the body of evidence. 


\section{The Impact of an Evidence-Based Multi-component Intervention on Colorectal Cancer Screening in Primary Care at a Healthcare System}

"Dying from embarrassment" may be more than a saying when it comes to colorectal cancer. Colorectal cancer (CRC) is the second most common cause of cancer deaths in the United States (American Cancer Society [ACS], 2020; Centers for Disease Control and Prevention [CDC], 2020). However, the five-year survival rate can be as high as $90 \%$ when CRC is detected in its early stage (Agency for Healthcare Research and Quality [AHRQ], 2018; ACS, 2020; CDC, 2020). A critical component in early detection is colorectal cancer screening (CRCS) for adults between the ages of 50 and 75 (AHRQ, 2018; ACS, 2020; CDC, 2020). Despite improvements in access to CRCS, other barriers, such as lack of education, fear, and embarrassment (Reynolds et al., 2018), still pose obstacles in reaching higher screening rates. These barriers contribute to premature deaths that could have been prevented by a simple CRCS (Adams et al., 2018; Brouwers et al., 2011b, 2011a; Dolan et al., 2004).

The National Center for Health Promotion and Disease Prevention provides guidance for a comprehensive CRC prevention and screening program (U.S. Department of Veterans Affairs [USDVA], 2020a). At the project site, a Veterans Affairs (VA) healthcare system, the CRCS rate from a 2020 random audit $(75.6 \%)$ was below the national benchmark of $80 \%$ (National Colorectal Cancer Roundtable [NCCRT], 2021; Office of Disease Prevention and Health Promotion [ODPHP], 2020a; U.S. Department of Veterans Affairs [USDVA], 2020c). Mitigating missed opportunities to prevent avoidable deaths by increasing CRCS aligned with the VA's high reliability organization (HRO) journey (AHRQ, 2019; Grabowski \& Roberts, 1997). 
Estimates of deaths due to CRC are over 50,000 per year in the United States (Siegel et al., 2018, p. 8). Tragically, many of these deaths could have been prevented with early screenings (CDC, 2020; National Committee for Quality Assurance, 2020; Redaelli et al., 2003; Wilkins et al., 2018; Wolf et al., 2018). Because CRC does not produce symptoms until the more advanced stages, screening before symptoms appear is crucial for early detection (Wilkins et al., 2018; Wolf et al., 2018).

In addition to the societal impact of morbidity and untimely deaths caused by CRC, CRC's economic burden is significant (Dieguez et al., 2017; Yabroff et al., 2008, 2011). Yabroff et al. (2011) estimated CRC costs $\$ 14.1$ billion per year in the United States. Due to its relatively long disease course, CRC has one of the highest economic cancer burdens (Yabroff et al., 2008). Costs include frequent surveillance procedures, surgeries, chemotherapy, radiation therapy, and inpatient comfort care (Redaelli et al., 2003). In addition to healthcare costs, CRC causes an economic burden due to lost productivity by the patient (Bradley et al., 2011; Pearce et al., 2016). Bradley et al. (2011) projected that lost productivity caused by CRC would be $\$ 4.2$ billion in $2020($ p.5)

Most CRCs begin as slow-growing, pre-cancerous polyps (Tobi, 1999). The identification and treatment of pre-cancerous polyps while the lesions are in a localized stage significantly increase survival chances (ACS, 2020; Siegel et al., 2018). Two methods for CRC screenings include stool-based tests and visual examination (Levin et al., 2008; Wilkins et al., 2018; Wolf et al., 2018). The colonoscopy is the most common visual examination CRCS procedure (Levin et al., 2008; Wilkins et al., 2018; Wolf et al., 2018). An example of a common stool-based test is the fecal immunochemical test or FIT (Levin et al., 2008; Wilkins et al., 2018; Wolf et al., 2018) . Data from 2018 shows that $25 \%$ of U.S. adults did not get screened for CRC (CDC, 2021). 
Reducing the prevalence, morbidity, and mortality caused by cancer is one of the leading health indicators of Healthy People 2020 and Healthy People 2030 (ODPHP, 2020a, 2020b). The goal of both Healthy People 2020 and 2030 is to improve wellness by prioritizing the prevention of health threats on the U.S. population (ODPHP, 2020a, 2020b). To reduce the health threat of CRC, prevention must address cultural disparities and stigma associated with the disease (Goldman et al., 2009; NCCRT, 2021).

\section{Health Literacy and Colorectal Cancer}

A relationship exists between a low health literacy rate and adherence to CRCS recommendations (Arnold et al., 2012; Dolan et al., 2004). The veteran_population at this facility may have a higher percentage of low health literacy levels than the general U.S. adult population (Nouri et al., 2019; Rodríguez et al., 2013). This organization's primary mission is to honor its customers by providing "exceptional health care that improves their health and well-being" (USDVA, 2019, "VHA Mission," para. 6). Therefore, healthcare providers working at the facility had professional and organizational obligations to maximize efforts for improving CRCS rates among veterans.

\section{PICOT Question}

Exploration of the current state of this organization and available evidence-based literature led to this PICOT question: Among veterans 50 - 75 years old requiring average risk CRCS seen in primary care at a VA healthcare system $(\mathrm{P})$, how does the use of a multi-component intervention to increase CRC screening (I), compared to usual care (C), affect the number of patients completing CRCS (O), in twelve weeks $(\mathrm{T})$ ?

The CRCS process at VA facilities was governed by the VA national directive 1015 (USDVA, 2020a). The directive alone, however, was insufficient to ensure the evidence-based 
practice was translated into practice. The purpose of this project was to support the intent of the directive by using a multi-component approach for promoting CRCS. The components included a combination of interventions, which were classified into three categories: a) increasing demand, b) increasing access, and c) increasing provider delivery (Mohan et al., 2019). This scholarly project increased demand and improved provider delivery by standardizing care coordination and navigation through the CRCS process.

\section{Evidence-Based Practice Framework and Change Theory}

\section{John’s Hopkins Nursing Evidence-Based Practice Framework}

The Johns Hopkins Nursing Evidence-Based Practice (JHNEBP) Model provided the framework for implementing this project (Dang \& Dearholt, 2017). The model was developed for easy practical application in clinical settings by nurses and interdisciplinary teams (Brooks-Staub, 2005). The first step was inquiry into a practice question. Next, a continuous loop of learning and practical application surrounded the core steps of: practice question, evidence, and translation, or PET (Dang \& Dearholt, 2017).

For this scholarly project, the evidence-based practice inquiry began with questioning why CRCS rates at this organization were below national benchmarks. This resulted in the development of the PICOT question. The evidence phase involved exploring the available body of literature and scrutinizing findings for quality using the JHNEBP Model for rating evidence (Dang \& Dearholt, 2017). The results were synthesized into actionable information.

Consideration of the evidence strength was weighed against the risk-benefit. Alignment with the organization's mission was considered to determine whether the practice change moved forward to implementation or was suspended. The final step was to disseminate outcomes and any new lessons learned (Dang \& Dearholt, 2017). 


\section{ADKAR Change Management Theory}

The change management theory that guided this project was ADKAR (Hiatt, 2006). It was a good fit for this project because ADKAR had been endorsed by the VA as its change management theory (USDVA, 2020a). The acronym ADKAR represents the five components that must be met before a successful change is sustained into practice: awareness, desire, knowledge, ability, and reinforcement (Hiatt, 2006). Since each condition builds upon the other, each step had to be accomplished in sequence to avoid adoption failure (Hiatt, 2006).

The first condition was awareness (Hiatt, 2006). Stakeholders were made aware that a change was necessary (Hiatt, 2006; Wong, 2019). Communication was a critical element in this step. The stakeholders were provided with comparison data that showed their specific clinic's performance and the entire facility's performance compared with that of other facilities across the nation.

The next step was creating desire in the stakeholders to engage the change (Hiatt, 2006; Wong, 2019). The desire to improve CRCS rates was built by illustrating the deadly impact on patients of failure to have timely screening. The leadership sought to make the facility the number one healthcare organization in the country. Sharing substandard performance data drove the stakeholders' desire to change.

Gaining knowledge of how to change and applying it to facilitate changes in workflow were critical steps (Hiatt, 2006). Those involved in the change must be informed about how the change will impact their workflow (Hiatt, 2006). Knowledge gaps were addressed by providing information to the primary care staff on the new standard work process, which structured a procedure for CRC care coordination to help patients navigate the CRCS process. 
Once the affected individuals possessed relevant knowledge, they had to be able to execute the change (Hiatt, 2006). For example, discussing CRC screening concerns with the patient may have been ineffective if the clinician was unable to move the conversation to a private place. The most significant gap in ability was correctly documenting in the electronic health record (EHR) clinical reminder system as well as using the available reports through the CRC aggregate database.

The final change model step was reinforcement (Hiatt, 2006). Previous estimates reported $70 \%$ of organizational changes that were attempted were not sustained (Jones-Schenk, 2019; Leonard \& Coltea, 2013; Nohria \& Beer, 2000). During the project, graphs and charts of the metrics were provided for the daily huddle board. In the future, creating and using an automated visual management system, such as a digital dashboard, would help maintain ongoing awareness and sustainability (Silver et al., 2016; Ulhassan et al., 2015).

\section{Evidence Search Strategy}

The search strategy utilized many databases through the University of St. Augustine for Health Sciences (USAHS) and the facility's online libraries. These included ProQuest, PubMed, and CINAHL. The inclusion criteria were: peer-reviewed, original research articles, in English, that were published between 2010 to present (October 2020). The timeframe was limited to the past ten years to ensure results were current. Keywords for the search guided by the PICOT question were "colorectal cancer screening," "intervention," "study," "compliance," "adherence," and a truncated, wildcard version of the word multi-component (multi\$ or multi*). The Boolean operator "OR" was used for the search "compliance OR adherence." Due to the large number of initial ProQuest results (number), an additional search filter was applied: "primary care," and the subject was limited to "colorectal cancer." 


\section{Evidence Search Results}

The exhaustive search returned CINAHL (52 articles), PubMed (170), and ProQuest (was 2,473 , reduced to 192). After removing duplicates, the studies that addressed the PICOT question $(n=14)$ were analyzed with a full-text reading of each. Four additional articles found during a review of reference lists of the 14 included studies were deemed suitable for full text review. The final 18 studies included randomized control trials, quasi-experimental studies, cross-sectional cohort studies, and three systematic reviews. See Figure 1 for the Prisma search strategy.

The evidence strength and quality were appraised using the Johns Hopkins Evidence Rating scheme (Dang \& Dearholt, 2017). See Figure 2 for the JH Nursing Evidence-Based Practice Evidence Strength Rating. Evidence rating allowed for scrutiny of the studies, which resulted in the calculation of an overall strength level.

The first component (level of evidence) was determined by the study type. Level I is considered the highest level and includes studies such as randomized-controlled trials. The lowest level (Level V) includes non-research publications such as quality improvement and case reports (Dang \& Dearholt, 2017). The quality rating ranges from low to high, with specific criteria for each category based on evidence level (Dang \& Dearholt, 2017). For example, for evidence Levels I to III, a randomized-controlled study with adequate sample size, definitive, generalizable results supported by the body of evidence would rank as high quality.

Evidence tables in Appendices A and B provide ratings of the study strengths. Nine individual studies were appraised at Level I, randomized controlled trials (RCT) of high quality, or Grade A (Baker et al., 2014; Coronado et al., 2018; Davis et al., 2017; Fitzgibbon et al., 2016; Green et al., 2013, 2017; Hendren et al., 2014; 2013; Wong et al., 2018). Dodd et al.'s (2019) study was appraised at Level $\mathrm{C}$ for concerns with validity due to insufficient sample size. Five 
studies were appraised to be Level II, and four were Grade A (Chou et al., 2016; Fortuna et al., 2014; Tu et al., 2014; Yu et al., 2018) and one Grade B (Basch et al., 2015). Three systematic reviews directly relevant to the PICOT question were also included (see Appendix B). For evidence levels, one was appraised as Level I (Dougherty et al., 2018), and the other two were Level II (U.S. Department of Health and Human Services [USDHHS], 2019; Young et al., 2019). All three were graded as high quality.

\section{Themes with Practice Recommendations}

A thorough and rigorous review of the existing literature on the use of a multi-component strategy to increase CRCS revealed several themes (see Appendix C).

\section{Patient Outreach}

The use of patient outreach through non-tailored reminder letters was demonstrated as effective in numerous studies. These included six randomized control trials (RCTs) of high quality (Baker et al., 2014; Coronado et al., 2018; Green et al., 2013, 2017; Hendren et al., 2014; Myers et al., 2013) two quasi-experimental, high quality studies (Fortuna et al., 2014; Yu et al., 2018) and one level II good quality systematic review, or SR (UDHHS, 2019). Only Myers et al. (2013) compared tailored versus non-tailored reminder letters in a high quality RCT, and the results failed to show any statistically significant difference between the two.

Colorectal cancer screening rates increased with the use of automated voicemails in three high quality RCTs and one SR (Baker et al., 2014; Fortuna et al., 2014; Hendren et al., 2014; USDHHS, 2019; Wong et al., 2018). Results using text messaging were inconsistent. One high quality RCT demonstrated an increase with text messages (Baker et al., 2014). Two studies, one high quality RCT (Wong et al., 2018), and one high quality quasi-experimental study 
(Fortuna et al., 2014) showed no difference in CRCS rates with either automated phone messages or text messages.

Distributing fecal occult blood testing (FOBT) kits by mail or in person was demonstrated to be a successful outreach approach. Seven high and one low-quality RCTs (Baker et al., 2014; Chou et al., 2016; Dodd et al., 2019; Green et al., 2013, 2017; Hendren et al., 2014; Myers et al., 2013), two quasi-experimental, good-quality studies (Chou et al., 2016; Yu et al., 2018) and two SRs of high quality (Dougherty et al., 2018; USDHHS, 2019) showed providing FOBT kits to patients increased CRCS.

Navigators help patients manage medical conditions by guiding care and providing education (National Cancer Institute, n.d.). The use of navigators showed consistently effective results. Five RCTs (four high quality; one low quality), three quasi-experimental studies of good to high quality, and three high quality SRs (one Level I; two Level II) (Baker et al., 2014; Basch et al., 2015; Dodd et al., 2019; Dougherty et al., 2018; Fortuna et al., 2014; Green et al., 2013; Myers et al., 2013; USDHHS, 2019; Wong et al., 2018; Young et al., 2019; Yu et al., 2018) showed increases with CRCS rates. However, there were inconsistencies in the type of staff used for navigators.

\section{Patient Education}

Two SRs (one Level I and one Level II, both high quality) demonstrated benefits of with patient education when coupled with other interventions (Dougherty et al., 2018; USDHHS, 2019). The results from a Level II high quality SR by Young et al. (2019) showed that the outcome was inconclusive. The effectiveness varied with the delivery mode of the information. Eleven studies, eight of which were high quality RCTs and one low (Baker et al., 2014; Davis et al., 2017; Dodd et al., 2019; Fitzgibbon et al., 2016; Green et al., 2013, 2017; Hendren et al., 
2014; Myers et al., 2013), three quasi-experimental good to high quality studies (Basch et al., 2015; Fortuna et al., 2014; Tu et al., 2014) were consistent in demonstrating that printed material was effective. Results from the use of videos were inconsistent (Chou et al., 2016; Davis et al., 2017; Fitzgibbon et al., 2016; Tu et al., 2014).

\section{Clinician Interventions}

The final theme identified was clinician-directed interventions. One strategy to change provider behavior was educating (academic detailing) physicians and mid-level providers. It showed promising results. Academic detailing (AD) refers to using peer subject matter experts to provide education on a targeted practice issue (AHRQ, 2013). Fitzgibbon et al. (2016), in a high quality RCT, demonstrated that AD was effective. Still, Basch et al. (2015), in their quasiexperimental, good quality study, did not have statistically significant differences with AD. However, there were improved CRCS adherence rates in the intervention group.

The high quality RCT by Fitzgibbon et al. (2016) and the Level II high quality SRs by Young et al. (2019) demonstrated provider feedback on their patient panels performance increased CRCS adherence rates. Two Level II high quality SRs showed EHR pop-up screening reminder alerts were effective when combined with other interventions (USDHHS, 2019; Young et al., 2019).

\section{Practice Recommendations}

The overwhelming body of evidence supported the use of a multi-component intervention to address the PICOT question, which focused on increasing CRCS in primary care (PC) clinics. The systematic review by the Community Preventive Services Task Force, or CPSTF (USDHHS, 2019), a group of independent subject matter experts, also served as a clinical practice guideline for this clinical issue. The multi-component intervention aimed at a practice change within the 
primary care clinics included a standardized CRCS nurse navigation process and provider feedback.

These elements were selected as the multi-component bundle for several reasons. First, the literature strongly supported these interventions as the most effective and targets all three categories in the CPSTF guideline (see Figure 3). Secondly, the organization's infrastructure allowed for ease of implementation because of the existing national Colorectal Cancer Screening and Surveillance (CRCS/S) database and the primary care $\mathrm{RN}$ care managers already in place. Lastly, the interventions were able to be executed with minimal cost impact to the organization.

\section{Setting, Stakeholders, and Systems Change}

\section{Project Overview}

The intervention was applied at three primary care (PC) Patient Aligned Care Teams (PACT) clinics (Clinics J, K and L) located on the main campus of a high complexity VA healthcare system in California. The PACT team is the VA's version of the medical home model (USDVA, 2020d). This VA is undergoing a lean, cultural transformation and was also pursuing Magnet to support their vision of becoming an HRO.

The number of patients eligible for average risk CRCS during the 12-week period was 3623. The number of eligible patients who were dispensed a FIT kit during the 30-day data collection period was 189 . The participant size was adequately powered based on Wong et al.'s (2018) randomized, eight-month, three-arm study comparing CRCS interventions. They calculated 600 participants as the sample size necessary to provide $80 \%$ power to detect an $11 \%$ increase in the intervention group (Wong et al., 2018). The observation period for this Doctor of Nursing (DNP) project was one month, which was $1 / 8^{\text {th }}$ of Wong et al.'s study duration.

Therefore, this project's participant count of 189 was appropriate to determine significance. Since 
most female patients within this organization opted to receive their care in the Women's Clinic instead of the PC clinic, most of the patients impacted were male patients ages 50 to 75 (see Table 3).

The need for this project was identified by evaluating data from the VA's quality tracking program (Strategic Analytics for Improvement and Learning Value Model - SAIL). It compiles data from approximately 170 nationwide facilities and includes 25 measures and multiple submeasures (USDVA, 2020b). This facility's ranking for the CRCS measure was below other comparable facilities and therefore identified as a need. The preceptor, the deputy associate director for patient care services endorsed and confirmed support for the project. She was also part of the executive leadership team. The PC leadership team and the PACT RN Coordinator also supported the project.

\section{Interprofessional Stakeholders}

A great deal of interprofessional stakeholder collaboration was needed for this project. Those directly impacted were nursing, medical, and clerical staff in the primary care (PC) clinics. Assistance from medical media, patient education, and public affairs staff was needed to develop and modify patient education materials. The supply chain department manager and the FIT kit vendors were also stakeholders. Leadership stakeholders included the PC physician and nurse chiefs, the directors for nursing (director and deputy for patient care services), and the chief of staff, who had ultimate clinical practice oversight in PC.

\section{Systems Change}

The scopes for changes that DNPs impact are categorized into three levels: macro, micro and meso (Moran, 2020; Rubio \& Scott, 2011; Trautman et al., 2018). Macro level changes occur within a large-scale population, such as at a national level (Moran, 2020). A more localized group, 
such as a city or community, is considered the meso level (Moran, 2020). Micro level changes are those that take place at an organizational level, like those achieved by this scholarly project (Moran, 2020). Although this evidence-based project was scoped at the micro-level to change primary care's CRCS process at the facility level, the plan is to expand to the meso level by partnering with other local and state organizations who provide care to similar populations.

The SWOT (strength, weakness, opportunities, threats) analysis is a method to assess factors that may positively impact or put the project at risk (Stonehouse, 2018). The SWOT analysis for this project showed many strengths, such as RN care managers who were already in place and an existing lean process improvement culture (see Appendix D). The most concerning threat was the impact of the COVID-19 pandemic on project implementation or completion. The project's process metrics were closely monitored to ensure threats or weaknesses were quickly identified and mitigated. See Table 2 for metrics that were monitored.

\section{Implementation Plan with Timeline and Budget}

\section{Project Plan}

After receiving approval for the project proposal implementation from the University's DNP Evidence-Based Practice Review Council and the facility IRB, the intervention took place over 12-weeks between March and June 2021 at three primary care (PC) clinics (clinics J, K, and L). The full schedule of activities is outlined in Appendix E. As the project manager, the DNP student was critical in implementing the project and following it through sustainment (Burson \& Moran, 2020). A skilled project manager is critical because they must strategically plan and anticipate potential barriers along the change management process (Conrad, 2020). Failing to adequately prepare to manage the change process can cause the project to fail (Campbell, 2020). The essential skills of a project manager to produce a successful team collaboration include 
effective communication skills, leadership, creativity, ability to inspire others, and change management (Harris, 2015). Coaching and guiding the team to stay motivated and persist amid multiple projects is another crucial function for the project manager (Harris \& Ward-Presson, 2015).

The preceptor, faculty, and the nurse scientist served as coaches to guide the project manager through the project. The executive sponsor, who was also the preceptor, was the deputy associate director for patient care services. She provided the necessary executive level support to vet the project's importance and support for utilizing resources for the project. The PC chief physician and the chief nurse helped mitigate change resistance encountered at the PC staff level. Other professionals required for collaboration included the gastroenterology (GI) providers, the data analyst, the supply chain department manager, and the laboratory manager. Collaborating with the GI providers offered insight from their experience as providers receiving consultations for patients referred for colonoscopies from positive CRCS tests. The data analyst was needed to assist with data mining and extraction of performance reports. The supply chain department supplied the FIT kits, and their expertise was necessary to maintain adequate supplies and to determine cost.

\section{Objectives and Timeline}

The primary objective was to increase CRCS adherence. The outcome measure was the percent of returned FIT kits within 30 days of distribution. The target was to increase the return rate by at least $10 \%$ from the baseline of $16.7 \%$. The intervention included a multi-component strategy. This included a standard work that guided the RN care managers through a systematic process for monitoring CRCS status, navigating the patient successfully through the screening (see Appendix H), and providing feedback to the PACT teams on their performance with CRCS. 
Another objective was to increase the number of PC nurses who used the Colorectal Cancer Screening Surveillance (CRCS/S) database, which contained data to facilitate CRC prevention. There was a gap in a standardized approach for CRC prevention. The inconsistencies contributed to the substandard CRCS adherence rates. The standard work provided guidance on using the $\mathrm{CRCS} / \mathrm{S}$ database, thereby improving the nurses' ability to function more effectively as navigators.

The final objective was to decrease the number of CRCS-positive patients waiting for provider follow up over 30 days by $20 \%$. The mean number of patients waiting at baseline for the three intervention clinics was 16 . By utilizing a report in the CRCS/S database that identified patients waiting for follow up, the care managers were able to collaborate with the provider and patient to remove barriers to follow up.

\section{Implementation Framework}

The JHEBP model guided the project (Dang \& Dearholt, 2017). Any CRC rates below the $80 \%$ national benchmark published by the NCCRT (2021) was a significant clinical practice issue. Failing to meet the benchmark meant that patients were needlessly dying from preventable cancer. The translation of evidence into practice included implementing a multi-component CRCS standard work multi-component bundle.

The ADKAR was the change model informing the project (Wong, 2019). Facilitating transformative change was an essential skill in implementing evidence-based practice (KendallGallagher \& Breslin, 2013). Encountering resistance to change was common (Campbell, 2020; Hiatt, 2006; Kendall-Gallagher \& Breslin, 2013; Wong, 2019). Applying an effective change management strategy mitigated some of the resistance (Campbell, 2020; Hiatt, 2006; Wong, 2019). 
Raising awareness and creating the desire to change were accomplished by disseminating and explaining the rationale for each step in the standard work. The knowledge and ability to implement the change was validated by the $\mathrm{RN}$ care manager and nurse manager, who audited the application of the new standard work in clinical practice. The reinforcement component of the change model was initiated through random audits of the nursing documentation in the EHR. Feedback about the PC team's performance on the metrics (see Table 2) was shared by displaying the weekly metrics at the daily huddle board. These metrics supported sustainment.

\section{Budget}

Expenses for the project above normal operation costs were minimal (see Table 1). The costs included the salary for additional time to provide comprehensive patient teaching and follow up phone calls. The total salary estimated for the duration of the project was $\$ 20,631$. Details of the other costs such as costs associated with photocopying and supplies are outlined in Table 1.

\section{Results}

The Intellectus Statistics (2021) online program was utilized for descriptive and quantitative statistical analyses. Participants were patients enrolled at one of the intervention clinics (Clinic J, K, or L), ages 50 to 75, and eligible for average-risk CRCS. Patients considered high risk, such as those with a history of CRC or under surveillance for suspicious polyps, were excluded. The participants were predominantly male $(n=1672,96 \%), 4 \%$ female $(n=77)$, with a mean age of 64.1 (see Table 3).

\section{FIT Kits Returned}

The primary outcome included the number of CRCS FIT kits returned by the patient within 30 days. Thirty days of data were compared at baseline and post-intervention. The result of the two proportions z-test did not reach statistical significance based on an alpha value of 
$0.05, \mathrm{z}=-1.02, \mathrm{p}=.307,95 \% \mathrm{CI}=[-0.12,0.04]$. This suggests the difference between FIT kits returned pre and post-intervention were not statistically significant (see Table 4). However, Figure 4 displays the upward trend in the number of FIT kits returned. The upward trend is clinically significant as it shows an improvement in returned FIT kit rates. The early detection of CRC is contingent on a robust FIT test monitoring program. The median turnaround time for patients to turn in their FIT tests is 44.5 days (Haas et al., 2019). Twelve weeks may have been an insufficient duration for demonstrating the full impact of the intervention due to the average lag time for returning FIT kits.

\section{Follow-up for Abnormal FIT Screens}

A secondary outcome metric was the number of patients pending follow-up greater than 30 days from the time of positive FIT test results. A two-tailed independent samples t-test was conducted to compare the total numbers of patients pending at baseline $(n=49)$ and postintervention $(\mathrm{n}=37)$. Normality assumption was met through the Shapiro-Wilk test (Razali \& Wah, 2011). The result was not statistically significant based on an alpha value of $0.05, t(4)=$ $0.45, p=.675$, (see Figure 5). Reasons the results may have failed to reach statistical significance may have been due to the short duration of the project and the small participant size for this subset. In addition, the "creating desire portion" of the ADKAR change model took much longer than expected. Furthermore, Clinic L's performance appeared to be an outlier caused by one provider's practice (see Figure 6). There was, however, a downward trend in the number of patients pending over 30 days for an abnormal FIT test follow-up, which is clinically significant as this means there was an improvement in patients receiving timely follow-up for abnormal FIT screenings.

\section{Overdue Colorectal Cancer Screening}


The proportion of overdue CRCS in the intervention clinics was one of the process metrics. The number of eligible patients overdue compared to all eligible patients was analyzed with the two-tailed independent samples t-test pre and post-intervention. The result was not significant based on an alpha value of $0.05, \mathrm{t}(4)=0.34, \mathrm{p}=.754$ (see Figure 7). It is very likely that the duration of this project was insufficient to demonstrate the impact on all eligible patients.

\section{Nursing Documentation}

Another process metric was a manual charting documentation audit. The audit of the EHR was done pre and post to monitor compliance with patient teaching about the FIT kit process (see Appendix G). The normality assumption was met using the Central Limit Theorem (CLT) (Pituch \& Stevens, 2015). The result of the two proportions $z$-test was significant based on an alpha value of $0.05, z=-5.62, p<.001,95 \% \mathrm{CI}=[-0.65,-0.31]$, (see Table 5). The statistical significance means that compliance with patient education documentation improved post-intervention (see Figure 8). This result is clinically significant because educating patients about the importance of completing the screening is critical in improving FIT kit return rates. In addition, patients need to be informed about their role in health promotion and illness prevention as a means for empowering patients to take charge of their health.

\section{Colorectal Cancer Screening and Surveillance Database Use}

The third process metric was the frequency of CRCS/S database use pre and postintervention collected through an internally created questionnaire (see Appendix F). The face validity for this internally developed tool (see Appendices F and G) was established through consulting six subject-matter experts who deemed the tool valid. The result of the two proportions $z$-test comparing the difference in the database use pre and post was not significant based on an alpha value of $0.05, z=-0.82, p=.414,95 \% \mathrm{CI}=[-0.46,0.19]$, (see Table 6). The 
baseline usage rates may have been falsely elevated due to staff confusion about the term "database" and interpreting it as the clinical reminder used in the EHR. There was, however, an uptrend in the usage of the database post-intervention (see Figure 10). Although not statistically significant, the increased use is clinically significant because consistent usage of the database is important for efficiently identifying the status of CRCS and pending follow-up for each patient. Using the database consistently can ensure patients receive timely management of CRC.

\section{Balancing Metric and Data Security}

The balancing metric monitored was the amount of overtime caused by the potential increase in nurse workload from the project. Payroll data was extracted through a centralized database to assess the impact on overtime caused by the intervention. The results showed no increase in overtime as a result of the intervention (see Figure 9).

\section{Data Integrity and Protection of Human Participants}

Automatically extracting data reduces the potential for human error (Mathes et al., 2017; Pandey et al., 2020). Therefore, the majority of the data were extracted automatically from the EHR and the centralized data warehouse. The only data manually extracted were the chart audits for nursing documentation and the CRCS/S questionnaire. To mitigate the risk of disclosing personally identifiable information (PII) and protect the patient, PII was coded, and data was stored electronically within the facility's restricted computer network. Access to the network is limited only to those who have a facility-issued microchipped access card and PIN. Electronic files with PII were restricted to the project manager and the preceptor.

\section{Impact}

Creating awareness was the first step in the ADKAR change model. The project alerted several significant clinical opportunities. This project was the first step in aligning this specific 
department to the organization's HRO journey and the HRO principles of preoccupation with failure and reluctance to simplify. This project highlighted and created awareness about the importance of monitoring routine health maintenance tracking processes.

For sustainment, the PC nurse leaders and champions have taken over as project managers to spread the multi-component approach to CRCSs to other PC locations and specialty clinics. A sustainment toolkit was provided, including process control spreadsheet templates, a video on how to conduct data analysis and CRCS database use, and a cheat sheet for clinicians on where to go for data and additional resources. The plan is to continue refining the standard work, audit the process, and continue tracking outcome metrics.

The project also highlighted significant challenges the clinicians face because of the antiquated EHR system, which may be contributing to alert fatigue. The need for the VA to modernize its EHR is well documented (Torres, 2014; USDVA, 2021). A locally created dashboard to simplify data interpretation will be critical for providing an efficient visual management tool for successfully sustaining positive outcomes.

Limitations of the project included competing priorities with the COVID-19 pandemic. Many of the regularly assigned staff and leaders in PC were reassigned out of PC to support pandemic-related activities, thus limiting their availability for the project. Finally, the project's duration was another limiting factor and a barrier to reaching some targeted goals. For example, the FIT kit return rates and the number of FIT positive patients pending follow-up greater than 30 days may have reached targets with a longer project duration.

\section{Dissemination and Future Plan}

The project outcomes were disseminated locally within the organization. The venues included presentations at various meetings including the facility's systems redesign and 
improvement team, Magnet ambassadors, PC staff, and the nursing research committee. A virtual session was recorded to allow staff not in attendance to watch at a later time.

In addition, presentations will be done at the facility-wide director's meeting. The director showcases facility projects every Friday morning at the director's meeting. The director's meeting is designed as the communication platform from the director to the chiefs but is open for any staff to attend. The facility's nursing grand rounds and evidence-based practice committee are other forums for future dissemination. The plan is to disseminate the findings to a greater audience outside of the local organization such as the annual nursing research conference, co-sponsored by this facility, its neighboring university's academic affiliate, and the parent organization's national nursing evidence-based poster presentation forum.

Plans for dissemination also include submitting the manuscript for publication to The Federal Practitioner journal. The Federal Practitioner is an appropriate match for manuscript submission and publishing because this peer-reviewed journal focuses specifically on the veteran population (MDedge, 2020). The Federal Practitioner uses a web-based editorial manager for peer review and is the only scholarly journal that addresses unique issues related to the veteran population and the VA healthcare system. The database used for implementing this project is unique to the VA. The Federal Practitioner readers would have access to this database, making the information generalizable to other veterans. Finally, the project will be submitted to the University of Saint Augustine for Health Sciences Library, Scholarship and Open Access Repository (SOAR) for archiving.

\section{Conclusion}

The intent of the project was to increase CRCS in the underserved population treated at this organization. This goal was met by implementing a CRCS multi-component intervention, 
including a standard work for PC nursing staff to function more effectively as CRCS navigators and by providing feedback on CRCS performance metrics. The standard work offered a systematic process for the current best-known way for identifying patients who are due for CRCS, those who have not returned their FIT kit, and those awaiting follow-up from a positive FIT test.

The project was limited to three PC clinics in one location. Disseminating this project's results will allow this EBP to spread to other PC clinics and specialty outpatient clinics. Implementing the project at specialty clinics such as the women's and spinal cord injury clinics would be just as important as in PCs. The project can also be implemented at other VA facilities across the nation. The dissemination of this project's results will facilitate reaching the $80 \%$ CRCS target established by the NCCRT, thereby saving millions of lives in the United States (2021). 


\section{References}

Adams, S. A., Rohweder, C. L., Leeman, J., Friedman, D. B., Gizlice, Z., Vanderpool, R. C., Askelson, N., Best, A., Flocke, S. A., Glanz, K., Ko, L. K., \& Kegler, M. (2018). Use of evidence-based interventions and implementation strategies to increase colorectal cancer screening in federally qualified health centers. Journal of Community Health, 43(6), 1044-1052. https://doi.org/10.1007/s10900-018-0520-2

Agency for Healthcare Research and Quality. (2013, May). Module 10-Academic detailing as a quality improvement tool. http://www.ahrq.gov/ncepcr/tools/pf-handbook/mod10.html Agency for Healthcare Research and Quality. (2018, April). Health care systems for tracking colorectal cancer screening tests. http://www.ahrq.gov/research/findings/finalreports/crcscreeningrpt/index.html

Agency for Healthcare Research and Quality. (2019, September). High reliability. AHRQ Patient Safety Network. https://psnet.ahrq.gov/primers/primer/31/High-Reliability

American Cancer Society. (2020). Colorectal cancer facts \& figures 2020-2022.

https://www.cancer.org/content/dam/cancer-org/research/cancer-facts-andstatistics/colorectal-cancer-facts-and-figures/colorectal-cancer-facts-and-figures-20202022.pdf

Arnold, C. L., Rademaker, A., Bailey, S. C., Esparza, J. M., Reynolds, C., Liu, D., Platt, D., \& Davis, T. C. (2012). Literacy barriers to colorectal cancer screening in community clinics. Journal of Health Communication, 17(0 3), 252-264. https://doi.org/10.1080/10810730.2012.713441

Baker, D. W., Brown, T., Buchanan, D. R., Weil, J., Balsley, K., Ranalli, L., Lee, J. Y., Cameron, K. A., Ferreira, M. R., Stephens, Q., Goldman, S. N., Rademaker, A., \& Wolf, 
M. S. (2014). Comparative effectiveness of a multifaceted intervention to improve adherence to annual colorectal cancer screening in community health centers: A randomized clinical trial. JAMA Internal Medicine, 174(8), 1235.

https://doi.org/10.1001/jamainternmed.2014.2352

Basch, C. E., Zybert, P., Wolf, R. L., Basch, C. H., Ullman, R., Shmukler, C., King, F., Neugut, A. I., \& Shea, S. (2015). A randomized trial to compare alternative educational interventions to increase colorectal cancer screening in a hard-to-reach urban minority population with health insurance. Journal of Community Health, 40(5), 975-983. https://doi.org/10.1007/s10900-015-0021-5

Bradley, C. J., Lansdorp-Vogelaar, I., Yabroff, K. R., Dahman, B., Mariotto, A., Feuer, E. J., \& Brown, M. L. (2011). Productivity savings from colorectal cancer prevention and control strategies. American Journal of Preventive Medicine, 41(2), e5-e14. https://doi.org/10.1016/j.amepre.2011.04.008

Brooks-Staub, K. (2005). The evidence is in. Johns Hopkins Nursing Magazine. https://magazine.nursing.jhu.edu/2005/12/the-evidence-is-in

Brouwers, M. C., De Vito, C., Bahirathan, L., Carol, A., Carroll, J. C., Cotterchio, M., Dobbins, M., Lent, B., Levitt, C., Lewis, N., McGregor, S. E., Paszat, L., Rand, C., \& Wathen, N. (2011a). Effective interventions to facilitate the uptake of breast, cervical and colorectal cancer screening: An implementation guideline. Implementation Science: IS, 6, 112. https://doi.org/10.1186/1748-5908-6-112

Brouwers, M. C., De Vito, C., Bahirathan, L., Carol, A., Carroll, J. C., Cotterchio, M., Dobbins, M., Lent, B., Levitt, C., Lewis, N., McGregor, S. E., Paszat, L., Rand, C., \& Wathen, N. (2011b). What implementation interventions increase cancer screening rates? A 
systematic review. Implementation Science, 6, 111. https://doi.org/10.1186/1748-5908-6111

Burson, R., \& Moran, K. (2020). Creating and developing the project plan. In K. Moran, R. Burson, \& D. Conrad (Eds.), The Doctor of Nursing practice: A framework for success (3rd ed., pp. 223-252). Jones \& Bartlett Learning.

Campbell, R. J. (2020). Change management in health care. The Health Care Manager, 39(2), 50-65. https://doi.org/10.1097/HCM.0000000000000290

Centers for Disease Control and Prevention. (2020, July 8). Basic information about colorectal cancer. https://www.cdc.gov/cancer/colorectal/basic_info/index.htm

Centers for Disease Control and Prevention. (2021, February 8). Use of colorectal cancer screening tests. https://www.cdc.gov/cancer/colorectal/statistics/use-screening-testsBRFSS.htm

Chou, C.-K., Chen, S. L.-S., Yen, A. M.-F., Chiu, S. Y.-H., Fann, J. C.-Y., Chiu, H.-M., Chuang, S.-L., Chiang, T.-H., Wu, M.-S., Wu, C.-Y., Chia, S.-L., Lee, Y.-C., Chiou, S.-T., \& Chen, H.-H. (2016). Outreach and inreach organized service screening programs for colorectal cancer. PloS One, 11(5). https://doi.org/10.1371/journal.pone.0155276

Conrad, D. (2020). Interprofessional and intraprofessional collaboration in the DNP project. In K. Moran, R. Burson, \& D. Conrad (Eds.), The Doctor of Nursing practice: A framework for success (3rd ed., pp. 187-206). Jones \& Bartlett Learning.

Coronado, G. D., Petrik, A. F., Vollmer, W. M., Taplin, S. H., Keast, E. M., Fields, S., \& Green, B. B. (2018). Effectiveness of a mailed colorectal cancer screening outreach program in community health clinics: The STOP CRC cluster randomized clinical trial. JAMA Internal Medicine, 178(9), 1174-1181. https://doi.org/10.1001/jamainternmed.2018.3629 
Dang, D., \& Dearholt, S. L. (2017). Johns Hopkins nursing evidence-based practice: Model and guidelines (3rd ed.). Sigma Theta Tau International.

Davis, S. N., Christy, S. M., Chavarria, E. A., Abdulla, R., Sutton, S. K., Schmidt, A., Vadaparampil, S. T., Quinn, G. P., Simmons, V. N., Ufondu, C., Ravindra, C., Schultz, I., Roetzheim, R., Shibata, D., Meade, C. D., \& Gwede, C. K. (2017). A randomized controlled trial of a multi-component targeted low-literacy educational intervention compared with a non-targeted intervention to boost colorectal cancer screening with fecal immunochemical test in community clinics. Cancer, 123(8), 1390-1400. https://doi.org/10.1002/cncr.30481

Dieguez, G., Ferro, C., \& Pyenson, B. S. (2017). Milliman research report: A multi-year look at the cost burden of cancer care. https://www.milliman.com/en/insight/2017/a-multi-yearlook-at-the-cost-burden-of-cancer-care

Dodd, N., Carey, M., Mansfield, E., Oldmeadow, C., \& Evans, T.-J. (2019). Testing the effectiveness of a general practice intervention to improve uptake of colorectal cancer screening: A randomised controlled trial. Australian and New Zealand Journal of Public Health, 43(5), 464-469. https://doi.org/10.1111/1753-6405.12913

Dolan, N. C., Ferreira, M. R., Davis, T. C., Fitzgibbon, M. L., Rademaker, A., Liu, D., Schmitt, B. P., Gorby, N., Wolf, M., \& Bennett, C. L. (2004). Colorectal cancer screening knowledge, attitudes, and beliefs among veterans: Does literacy make a difference? Journal of Clinical Oncology: Official Journal of the American Society of Clinical Oncology, 22(13), 2617-2622. https://doi.org/10.1200/JCO.2004.10.149

Dougherty, M. K., Brenner, A. T., Crockett, S. D., Gupta, S., Wheeler, S. B., Coker-Schwimmer, M., Cubillos, L., Malo, T., \& Reuland, D. S. (2018). Evaluation of interventions intended 
to increase colorectal cancer screening rates in the United States: A systematic review and meta-analysis. JAMA Internal Medicine, 178(12), 1645-1658. https://doi.org/10.1001/jamainternmed.2018.4637

Evidence-Based Cancer Control Programs. (2014, August 26). Healthy colon, healthy life: Telephone counseling script. https://ebccp.cancercontrol.cancer.gov

Fitzgibbon, M. L., Ferreira, M. R., Dolan, N. C., Davis, T. C., Rademaker, A. W., Wolf, M. S., Liu, D., Gorby, N., Schmitt, B. P., \& Bennett, C. L. (2016). Process evaluation in an intervention designed to improve rates of colorectal cancer screening in a VA medical center. Health Promotion Practice. https://doi.org/10.1177/1524839907302210

Fortuna, R. J., Idris, A., Winters, P., Humiston, S. G., Scofield, S., Hendren, S., Ford, P., Li, S. X. L., \& Fiscella, K. (2014). Get screened: A randomized trial of the incremental benefits of reminders, recall, and outreach on cancer screening. Journal of General Internal Medicine, 29(1), 90-97. https://doi.org/10.1007/s11606-013-2586-y

Gili, M., Roca, M., Ferrer, V., Obrador, A., \& Cabeza, E. (2006). Psychosocial factors associated with the adherence to a colorectal cancer screening program. Cancer Detection and Prevention, 30(4), 354-360. https://doi.org/10.1016/j.cdp.2006.06.005

Goldman, R. E., Diaz, J. A., \& Kim, I. (2009). Perspectives of colorectal cancer risk and screening among Dominicans and Puerto Ricans: Stigma and misperceptions. Qualitative Health Research, 19(11), 1559-1568. https://doi.org/10.1177/1049732309349359

Grabowski, M., \& Roberts, K. (1997). Risk mitigation in large-scale systems: Lessons from high reliability organizations. California Management Review, 39(4), 152-161. https://doi.org/10.2307/41165914 
Green, B. B., Anderson, M. L., Cook, A. J., Chubak, J., Fuller, S., Meenan, R. T., \& Vernon, S. W. (2017). A centralized mailed program with stepped increases of support increases time in compliance with colorectal cancer screening guidelines over 5 years: A randomized trial. Cancer, 123(22), 4472-4480. https://doi.org/10.1002/cncr.30908

Green, B. B., Wang, C.-Y., Anderson, M. L., Chubak, J., Meenan, R. T., Vernon, S. W., \& Fuller, S. (2013). An automated intervention with stepped increases in support to increase uptake of colorectal cancer screening: A randomized trial. Annals of Internal Medicine, 158(5 Pt 1), 301-311. https://doi.org/10.7326/0003-4819-158-5-201303050-00002

Haas, C. B., Phipps, A. I., Hajat, A., Chubak, J., \& Wernli, K. J. (2019). Time to Fecal Immunochemical Test completion for colorectal cancer screening. The American Journal of Managed Care, 25(4), 174-180. https://www.ncbi.nlm.nih.gov/pmc/articles/PMC7170013/

Harris, J. L. (2015). Key foundations of successful project planning and management. In J. L. Harris, L. A. Roussel, P. Thomas, \& C. Dearman (Eds.), Project planning \& management: A guide for nurses and interprofessional teams: Vol. 2nd ed (pp. 1-30). Jones \& Bartlett Learning.

Harris, J. L., \& Ward-Presson, K. M. (2015). Managing the interprofessional project team. In J. L. Harris, L. A. Roussel, P. Thomas, \& C. Dearman (Eds.), Project planning \& management: A guide for nurses and interprofessional teams: Vol. 2nd ed (pp. 100-120). Jones \& Bartlett Learning.

Hendren, S., Winters, P., Humiston, S., Idris, A., Li, S. X. L., Ford, P., Specht, R., Marcus, S., Mendoza, M., \& Fiscella, K. (2014). Randomized, controlled trial of a multimodal intervention to improve cancer screening rates in a safety-net primary care practice. 
Journal of General Internal Medicine, 29(1), 41-49. https://doi.org/10.1007/s11606-0132506-1

Hiatt, J. M. (2006). ADKAR: A model for change in business, government and our community. Prosci Research. https://www.prosci.com/adkar

Intellectus Statistics [Online Computer Software]. (2021). Intellectus Statistics. https://analyze.intellectusstatistics.com

Johns, M. B., Hovell, M. F., Ganiats, T., Peddecord, K. M., \& Agras, W. S. (1987). Primary care and health promotion: A model for preventive medicine. American Journal of Preventive Medicine, 3(6), 346-357. https://www.ajpmonline.org

Jones-Schenk, J. (2019). 70\% failure rate: An imperative for better change management. Journal of Continuing Education in Nursing, 50(4), 148-149. https://doi.org/10.3928/0022012420190319-03

Kendall-Gallagher, D., \& Breslin, E. (2013). Developing DNP students as adaptive leaders: A key strategy in transforming health care. Journal of Professional Nursing: Official Journal of the American Association of Colleges of Nursing, 29(5), 259-263. https://doi.org/10.1016/j.profnurs.2013.06.009

Leonard, D., \& Coltea, C. (2013). Most change initiatives fail—But they don't have to. Gallup Business Journal. https://news.gallup.com/businessjournal/162707/change-initiativesfail-don.aspx

Levin, B., Lieberman, D. A., McFarland, B., Smith, R. A., Brooks, D., Andrews, K. S., Dash, C., Giardiello, F. M., Glick, S., Levin, T. R., Pickhardt, P., Rex, D. K., Thorson, A., Winawer, S. J., American Cancer Society Colorectal Cancer Advisory Group, US MultiSociety Task Force, \& American College of Radiology Colon Cancer Committee. (2008). 
Screening and surveillance for the early detection of colorectal cancer and adenomatous polyps, 2008: A joint guideline from the American Cancer Society, the US Multi-Society Task Force on Colorectal Cancer, and the American College of Radiology. CA: A Cancer Journal for Clinicians, 58(3), 130-160. https://doi.org/10.3322/CA.2007.0018

Ling, B. S., Schoen, R. E., Trauth, J. M., Wahed, A. S., Eury, T., Simak, D. M., Solano, F. X., \& Weissfeld, J. L. (2009). Physicians encouraging colorectal screening: A randomized controlled trial of enhanced office and patient management on compliance with colorectal cancer screening. Archives of Internal Medicine, 169(1), 47-55. https://doi.org/10.1001/archinternmed.2008.519

Mathes, T., Klaßen, P., \& Pieper, D. (2017). Frequency of data extraction errors and methods to increase data extraction quality: A methodological review. BMC Medical Research Methodology, 17(1), 152. https://doi.org/10.1186/s12874-017-0431-4

MDedge. (2020). Federal Practitioner submission guidelines. https://www.mdedge.com/content/submission-guidelines-1

Mohan, G., Chattopadhyay, S. K., Ekwueme, D. U., Sabatino, S. A., Okasako-Schmucker, D. L., Peng, Y., Mercer, S. L., \& Thota, A. B. (2019). Economics of multicomponent interventions to increase breast, cervical, and colorectal cancer screening: A community guide systematic review. American Journal of Preventive Medicine, 57(4), 557-567. https://doi.org/10.1016/j.amepre.2019.03.006

Moher, D., Liberati, A., Tetzlaff, J., Altman, D. G., \& The PRISMA Group. (2009). Preferred Reporting Items for Systematic Reviews and Meta-Analyses: The PRISMA Statement. PLOS Medicine, 6(7), e1000097. https://doi.org/10.1371/journal.pmed.1000097 
Moran, K. (2020). Healthcare policy and advocacy. In K. Moran, R. Burson, \& D. Conrad (Eds.), The Doctor of Nursing Practice: A framework for success (3rd ed., pp. 65-94). Jones \& Bartlett Learning.

Myers, R. E., Bittner-Fagan, H., Daskalakis, C., Sifri, R., Vernon, S. W., Cocroft, J., Dicarlo, M., Katurakes, N., \& Andrel, J. (2013). A randomized controlled trial of a tailored navigation and a standard intervention in colorectal cancer screening. Cancer Epidemiology, Biomarkers \& Prevention: A Publication of the American Association for Cancer Research, Cosponsored by the American Society of Preventive Oncology, 22(1), 109117. https://doi.org/10.1158/1055-9965.EPI-12-0701

Myers, R. E., Ross, E., Jepson, C., Wolf, T., Balshem, A., Millner, L., \& Leventhal, H. (1994). Modeling adherence to colorectal cancer screening. Preventive Medicine, 23(2), 142151. https://doi.org/10.1006/pmed.1994.1020

Myers, R. E., Sifri, R., Hyslop, T., Rosenthal, M., Vernon, S. W., Cocroft, J., Wolf, T., Andrel, J., \& Wender, R. (2007). A randomized controlled trial of the impact of targeted and tailored interventions on colorectal cancer screening. Cancer, 110(9), 2083-2091. https://doi.org/10.1002/cncr.23022

National Cancer Institute. (n.d.). Definition of patient navigator. https://www.cancer.gov/publications/dictionaries/cancer-terms/def/patient-navigator

National Colorectal Cancer Roundtable. (2021). Achieving 80\% colorectal cancer screening rates in every community. https://nccrt.org/80-in-every-community

National Committee for Quality Assurance. (2020). Colorectal cancer screening. NCQA. https://www.ncqa.org/hedis/measures/colorectal-cancer-screening/ 
Nohria, N., \& Beer, M. (2000, May 1). Cracking the code of change. Harvard Business Review, May-June 2000. https://hbr.org/2000/05/cracking-the-code-of-change

Nouri, S. S., Damschroder, L. J., Olsen, M. K., Gierisch, J. M., Fagerlin, A., Sanders, L. L., McCant, F., \& Oddone, E. Z. (2019). Health coaching has differential effects on veterans with limited health literacy and numeracy: A secondary analysis of ACTIVATE. Journal of General Internal Medicine, 34(4), 552-558. https://doi.org/10.1007/s11606-01904861-7

Office of Disease Prevention and Health Promotion. (2020a, January 16). Healthy People 2030: Reduce the colorectal cancer death rate: C-06. https://health.gov/healthypeople Office of Disease Prevention and Health Promotion. (2020b, September 25). Cancer: Healthy People 2020. https://www.healthypeople.gov/2020/topics-objectives/topic/cancer Pandey, A. K., Khan, A. I., Abushark, Y. B., Alam, M. M., Agrawal, A., Kumar, R., \& Khan, R. A. (2020). Key issues in healthcare data integrity: Analysis and recommendations. IEEE Access, 8, 40612-40628. https://doi.org/10.1109/ACCESS.2020.2976687

Pearce, A., Bradley, C., Hanly, P., O’Neill, C., Thomas, A. A., Molcho, M., \& Sharp, L. (2016). Projecting productivity losses for cancer-related mortality 2011-2030. BMC Cancer, 16. https://doi.org/10.1186/s12885-016-2854-4

Percac-Lima, S., Grant, R. W., Green, A. R., Ashburner, J. M., Gamba, G., Oo, S., Richter, J. M., \& Atlas, S. J. (2009). A culturally tailored navigator program for colorectal cancer screening in a community health center: A randomized, controlled trial. Journal of General Internal Medicine, 24(2), 211-217. https://doi.org/10.1007/s11606-008-0864-x

Pituch, K. A., \& Stevens, J. P. (2015). Applied multivariate statistics for the social sciences (6th ed.). Routledge Academic. https://doi.org/10.4324/9781315814919 
Razali, N. M., \& Wah, Y. B. (2011). Power comparisons of Shapiro-Wilk, KolmogorovSmirnov, Lilliefors and Anderson-Darling tests. Journal of Statistical Modeling and Analytics, 2(1), 21-33. https://journals.sagepub.com/home/smj

Redaelli, A., Cranor, C. W., Okano, G. J., \& Reese, P. R. (2003). Screening, prevention and socioeconomic costs associated with the treatment of colorectal cancer.

PharmacoEconomics, 21(17), 1213-1238. https://doi.org/10.2165/00019053-20032117000001

Reynolds, L. M., Bissett, I. P., \& Consedine, N. S. (2018). Emotional predictors of bowel screening: The avoidance-promoting role of fear, embarrassment, and disgust. $B M C$ Cancer, 18. https://doi.org/10.1186/s12885-018-4423-5

Rodríguez, V., Andrade, A. D., García-Retamero, R., Anam, R., Rodríguez, R., Lisigurski, M., Sharit, J., \& Ruiz, J. G. (2013). Health literacy, numeracy, and graphical literacy among veterans in primary care and their effect on shared decision making and trust in physicians. Journal of Health Communication, 18(Suppl 1), 273-289. https://doi.org/10.1080/10810730.2013.829137

Rubio, A., \& Scott, L. (2011). Chapter 12: Leadership and the DNP-educated nurse executive. In H. M. Dreher \& M. E. S. Glasgow (Eds.), Role development for doctoral advanced nursing practice (pp. 242-260). Springer Publishing Company, Inc.

Sequist, T. D., Zaslavsky, A. M., Marshall, R., Fletcher, R. H., \& Ayanian, J. Z. (2009). Patient and physician reminders to promote colorectal cancer screening: A randomized controlled trial. Archives of Internal Medicine, 169(4), 364-371. https://doi.org/10.1001/archinternmed.2008.564 
Siegel, R. L., Miller, K. D., \& Jemal, A. (2018). Cancer statistics, 2018. CA: A Cancer Journal for Clinicians, 68(1), 7-30. https://doi.org/10.3322/caac.21442

Silver, S. A., McQuillan, R., Harel, Z., Weizman, A. V., Thomas, A., Nesrallah, G., Bell, C. M., Chan, C. T., \& Chertow, G. M. (2016). How to sustain change and support continuous quality improvement. Clinical Journal of the American Society of Nephrology : CJASN, 11(5), 916. https://doi.org/10.2215/CJN.11501015

Stonehouse, D. (2018). SWOT: What is it all about and how do you use it? British Journal of Healthcare Assistants, 12(12), 617-619. https://doi.org/10.12968/bjha.2018.12.12.617

Tobi, M. (1999). Polyps as biomarkers for colorectal neoplasia. Frontiers in Bioscience: A Journal and Virtual Library, 4, D329-338. https://doi.org/10.2741/tobi

Torres, N. (2014, June 24). Why the VA couldn't keep up with IT. Harvard Business Review. https://hbr.org/2014/06/why-the-va-couldnt-keep-up-with-it

Trautman, D. E., Idzik, S., Hammersla, M., \& Rosseter, R. (2018). Advancing scholarship through translational research: The role of $\mathrm{PhD}$ and DNP prepared nurses. Online Journal of Issues in Nursing, 23(2), 1-1. https://doi.org/10.3912/OJIN.Vol23No02Man02

Tu, S.-P., Chun, A., Yasui, Y., Kuniyuki, A., Yip, M.-P., Taylor, V., \& Bastani, R. (2014). Adaptation of an evidence-based intervention to promote colorectal cancer screening: A quasi-experimental study. Implementation Science: IS, 9, 85. https://doi.org/10.1186/1748-5908-9-85

Tu, S.-P., Taylor, V., Yasui, Y., Chun, A., Yip, M.-P., Acorda, E., Li, L., \& Bastani, R. (2006). Promoting culturally appropriate colorectal cancer screening through a health educator: A randomized controlled trial. Cancer, 107(5), 959-966. https://doi.org/10.1002/cncr.22091 
Ulhassan, W., von Thiele Schwarz Ulrica, Westerlund, H., Sandahl, C., \& Thor, J. (2015). How visual management for continuous improvement might guide and affect hospital staff: A case study. Quality Management in Health Care, 4, 222.

https://doi.org/10.1097/QMH.0000000000000073

U.S. Department of Health and Human Services. (2019). Cancer screening: Multicomponent interventions-Colorectal cancer. https://www.thecommunityguide.org/findings/cancerscreening-multicomponent-interventions-colorectal-cancer

U.S. Department of Veterans Affairs. (2019, July 14). About VHA - Veterans Health Administration. https://www.va.gov/health/aboutvha.asp

U.S. Department of Veterans Affairs. (2020a). The journey to transformation: Whole health clinical care. https://www.va.gov/wholehealth

U.S. Department of Veterans Affairs. (2020b, April 3). Colorectal cancer screening: VHA directive 1015. https://www.va.gov/vhapublications/ViewPublication.asp?pub_ID=8815

U.S. Department of Veterans Affairs. (2020c, June 11). Strategic Analytics for Improvement and Learning (SAIL)—Quality of care. https://www.va.gov/QUALITYOFCARE/measureup/Strategic_Analytics_for_Improvement_and_Learning_SAIL.asp

U.S. Department of Veterans Affairs. (2020d, November 5). Patient Aligned Care Team (PACT). https://www.patientcare.va.gov/primarycare/PACT.asp

U.S. Department of Veterans Affairs. (2020e, November 13). Are you FIT? https://www.prevention.va.gov

U.S. Department of Veterans Affairs. (2021, April 8). VA EHR modernization. https://www.ehrm.va.gov 
Vernon, S. W., Myers, R. E., \& Tilley, B. C. (1997). Development and validation of an instrument to measure factors related to colorectal cancer screening adherence. Cancer Epidemiology, Biomarkers \& Prevention: A Publication of the American Association for Cancer Research, Cosponsored by the American Society of Preventive Oncology, 6(10), 825-832. https://bloodcancerdiscov.aacrjournals.org

Weinstein, N. D., \& Sandman, P. M. (1992). A model of the precaution adoption process: Evidence from home radon testing. Health Psychology: Official Journal of the Division of Health Psychology, American Psychological Association, 11(3), 170-180. https://doi.org/10.1037//0278-6133.11.3.170

White, A., Sabatino, S. A., Vinson, C., Chambers, D., \& White, M. C. (2019). Advancing public health and implementation science. Preventive Medicine, 129, 105824. https://doi.org/10.1016/j.ypmed.2019.105824

Wilkins, T., McMechan, D., \& Talukder, A. (2018). Colorectal cancer screening and prevention. American Family Physician, 97(10), 658-665. https://www.aafp.org/afp/2018/0515/p658.html

Wolf, A. M. D., Fontham, E. T. H., Church, T. R., Flowers, C. R., Guerra, C. E., LaMonte, S. J., Etzioni, R., McKenna, M. T., Oeffinger, K. C., Shih, Y.-C. T., Walter, L. C., Andrews, K. S., Brawley, O. W., Brooks, D., Fedewa, S. A., Manassaram-Baptiste, D., Siegel, R. L., Wender, R. C., \& Smith, R. A. (2018). Colorectal cancer screening for average-risk adults: 2018 guideline update from the American Cancer Society. CA: A Cancer Journal for Clinicians, 68(4), 250-281. https://doi.org/10.3322/caac.21457

Wong, M. C., Ching, J. Y., Huang, J., Wong, J. C., Lam, T. Y., Chan, V. C., Ng, S. K., Hui, Z., Luk, A. K., Wu, J. C., \& Chan, F. K. (2018). Effectiveness of reminder strategies on 
cancer screening adherence: A randomised controlled trial. The British Journal of General Practice: The Journal of the Royal College of General Practitioners, 68(674), e604-e611. https://doi.org/10.3399/bjgp18X698369

Wong, Q. (2019). Leading change with ADKAR. Nursing Management, 50(4), 28-35. https://doi.org/10.1097/01.NUMA.0000554341.70508.75

Woudstra, A. J., Smets, E. M. A., Galenkamp, H., \& Fransen, M. P. (2019). Validation of health literacy domains for informed decision making about colorectal cancer screening using classical test theory and item response theory. Patient Education and Counseling, 102(12), 2335-2343. https://doi.org/10.1016/j.pec.2019.09.016

Yabroff, K. R., Lamont, E. B., Mariotto, A., Warren, J. L., Topor, M., Meekins, A., \& Brown, M. L. (2008). Cost of care for elderly cancer patients in the United States. Journal of the National Cancer Institute, 100(9), 630-641. https://doi.org/10.1093/jnci/djn103

Yabroff, K. R., Lund, J., Kepka, D., \& Mariotto, A. (2011). Economic burden of cancer in the US: Estimates, projections, and future research. Cancer Epidemiology, Biomarkers \& Prevention: A Publication of the American Association for Cancer Research, Cosponsored by the American Society of Preventive Oncology, 20(10), 2006-2014. https://doi.org/10.1158/1055-9965.EPI-11-0650

Young, B.-R., Gwede, C. K., Thomas, B., Vázquez-Otero, C., Ewing, A., Best, A. L., Aguado Loi, C. X., Martinez-Tyson, D., Schneider, T., Meade, C. D., Baldwin, J. A., \& Bryant, C. (2019). A systematic review of U.S.-based colorectal cancer screening uptake intervention systematic reviews: Available evidence and lessons learned for research and practice. Frontiers in Public Health, 7. https://doi.org/10.3389/fpubh.2019.00145 
Yu, C., Skootsky, S., Grossman, M., Garner, O. B., Betlachin, A., Esrailian, E., Hommes, D. W., \& May, F. P. (2018). A multi-level fit-based quality improvement initiative to improve colorectal cancer screening in a managed care population. Clinical and Translational Gastroenterology, 9(8), 177. https://doi.org/10.1038/s41424-018-0046-z 


\section{Table 1}

Budget

\section{EXPENSES}

\section{REVENUE}

Direct

\begin{tabular}{rcc} 
Salary (RN and LVN) & $\$ 20,631$ \\
Supplies - photocopies & $\$ 200$ & \\
Supplies - FIT Kit & $\$ 648$ & \\
FIT Kit processing & $\$ 817$ & \\
FIT Kit mailing & $\$ 600$ & Total Revenue \\
Statistician Consultation & $\$ 100$ & 0 \\
\hline Total Expenses & $\mathbf{\$ 2 2 , 9 9 6}$ & \\
Net Balance & $-\$ 22,996$ & \\
\end{tabular}




\section{Table 2}

\section{Project Measures}

\begin{tabular}{|c|c|c|c|c|c|c|c|c|c|c|c|c|c|c|c|c|c|c|c|c|c|c|}
\hline & \multicolumn{5}{|c|}{ Categories } & \multicolumn{13}{|c|}{ Time for Data Collection } & \multicolumn{2}{|c|}{$\begin{array}{c}\text { Statistical } \\
\text { Tests }\end{array}$} & \multicolumn{2}{|c|}{ Targets } \\
\hline Measures & 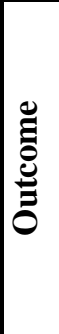 & 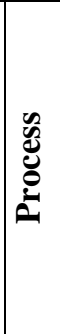 & صِّ & 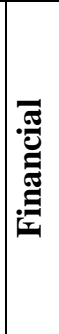 & 尝 & 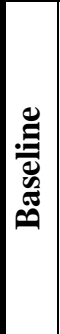 & $\begin{array}{l}-1 \\
\frac{y}{8} \\
3\end{array}$ & 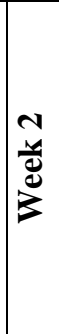 & 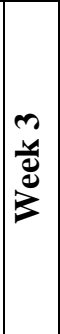 & 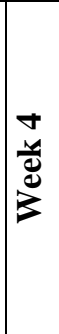 & 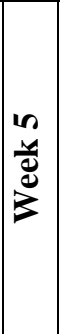 & 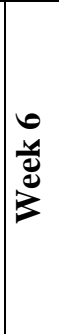 & 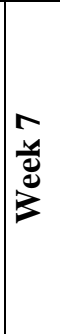 & 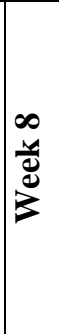 & $\begin{array}{l}a \\
\text { âd } \\
0 \\
3\end{array}$ & 象 & $\begin{array}{l}= \\
\bar{y} \\
\frac{1}{8} \\
3\end{array}$ & $\begin{array}{l}J \\
y \\
y \\
\\
z\end{array}$ & 产 & 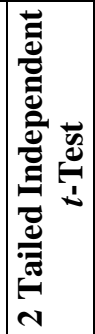 & 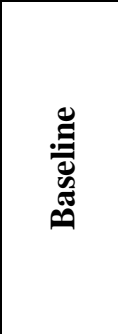 & ฮี \\
\hline $\begin{array}{l}\text { FIT kit returned in intervention clinics } \\
\text { Calculated by dividing the total number of patients } \\
\text { issued a FIT kit by the number returned within } 30 \text { days } \\
\text { data source: } \mathrm{CRCS} / \mathrm{S}\end{array}$ & $\mathbf{X}$ & & & & $\mathbf{X}$ & $\mathbf{X}$ & $\mathbf{X}$ & $\mathbf{X}$ & $\mathbf{X}$ & $\mathbf{X}$ & $\mathbf{X}$ & $\mathbf{X}$ & $\mathbf{X}$ & $\mathbf{X}$ & $\mathbf{X}$ & $\mathbf{X}$ & $\mathbf{X}$ & $\mathbf{X}$ & $\mathbf{X}$ & & $65 \%$ & $\geq 75 \%$ \\
\hline $\begin{array}{l}\text { Abnormal FIT follow-up in intervention clinics } \\
\text { The mean number of patients who have an abnormal FIT } \\
\text { test pending follow up }>30 \text { days - data source: CRCS/S }\end{array}$ & $\mathbf{X}$ & & & & $\mathbf{X}$ & $\mathbf{X}$ & $\mathbf{X}$ & $\mathbf{X}$ & & $\mathbf{X}$ & & & & $\mathbf{X}$ & & & & $\mathbf{X}$ & & $\mathbf{X}$ & 16 & $<12.8$ \\
\hline $\begin{array}{l}\text { Patients overdue for CRCS in intervention clinics } \\
\text { The number of patients who are overdue on their CRCS } \\
>30 \text { days - data source: CRCS/S. Denominator = } \\
\text { number of pts due for CRCS within a time period. } \\
\text { Numerator = number of patients who completed the } \\
\text { CRCS. }\end{array}$ & $\mathbf{X}$ & & & & $\mathbf{X}$ & $\mathbf{X}$ & $\mathbf{X}$ & $\mathbf{X}$ & & $\mathbf{X}$ & & & & $\mathbf{X}$ & & & & $\mathbf{X}$ & & $\mathbf{X}$ & $35.4 \%$ & $\leq 25 \%$ \\
\hline $\begin{array}{l}\text { EHR nursing documentation audit } \\
\text { Random manual audit of EHR nursing documentation of } \\
\text { CRCS patient counseling. Denominator = number of } \\
\text { audited charts. Numerator = number of nursing } \\
\text { documentation reflecting CRCS patient counseling - } \\
\text { data source: EHR }\end{array}$ & & $\mathbf{X}$ & & & & $\mathbf{X}$ & $\mathbf{X}$ & $\mathbf{X}$ & $\mathbf{X}$ & $\mathbf{X}$ & $\mathbf{X}$ & $\mathbf{X}$ & $\mathbf{X}$ & $\mathbf{X}$ & $\mathbf{X}$ & $\mathbf{X}$ & $\mathbf{X}$ & $\mathbf{X}$ & $\mathbf{X}$ & & $28.3 \%$ & $100 \%$ \\
\hline
\end{tabular}




\begin{tabular}{|c|c|c|c|c|c|c|c|c|c|c|c|c|c|c|c|c|c|c|c|c|c|c|}
\hline & \multicolumn{5}{|c|}{ Categories } & \multicolumn{13}{|c|}{ Time for Data Collection } & \multicolumn{2}{|c|}{\begin{tabular}{|c|} 
Statistical \\
Tests
\end{tabular}} & \multicolumn{2}{|c|}{ Targets } \\
\hline Measures & 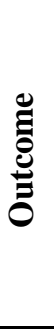 & 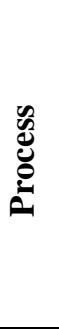 & 曷 & 苞 & 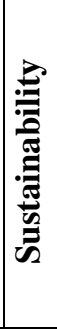 & 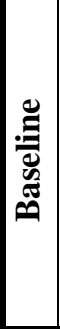 & $\begin{array}{l}\bar{y} \\
\bar{y} \\
\bar{d} \\
z\end{array}$ & 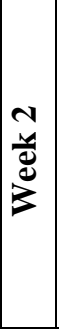 & $\begin{array}{l}n \\
y \\
y \\
z \\
z\end{array}$ & 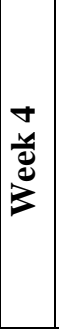 & 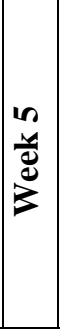 & 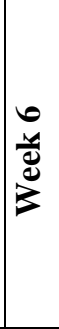 & 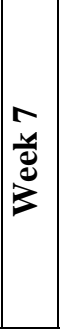 & 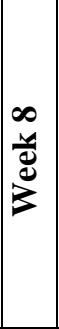 & 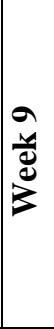 & 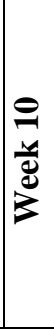 & 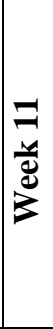 & 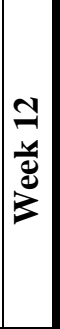 & 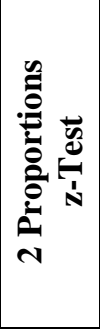 & 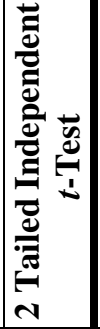 & 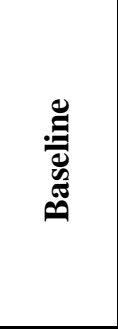 & రే \\
\hline $\begin{array}{l}\text { Nursing staff CRCS/S use questionnaire } \\
\text { Questionnaire for nursing staff regarding usage } \\
\text { frequency of CRCS/S database. Comparing frequency of } \\
\text { use pre-mid-post intervention. Denominator = } \\
\text { RNs/LVNs that respond to survey. Numerator = number } \\
\text { of RNs/LVNs that report uses the CRCS/S database at } \\
\text { least once per month }\end{array}$ & & $\mathbf{X}$ & & & & $\mathbf{X}$ & & & & & & $\mathbf{X}$ & & & & & & $\mathbf{X}$ & $\mathbf{X}$ & & $57.9 \%$ & $\underset{75 \%}{\geq}$ \\
\hline $\begin{array}{l}\text { Nursing overtime } \\
\text { Amount of nursing overtime hours increase after } \\
\text { intervention implementation }\end{array}$ & & & $\mathbf{X}$ & $\mathbf{X}$ & & $\mathbf{X}$ & & $\mathbf{X}$ & & $\mathbf{X}$ & & $\mathbf{X}$ & & $\mathbf{X}$ & & $\mathbf{X}$ & & $\mathbf{X}$ & $\mathbf{X}$ & & $\mathbf{N} / \mathbf{A}$ & $\leq 1 \%$ \\
\hline
\end{tabular}

Legend: CRCS - colorectal cancer screening; CRCS/S Colorectal Cancer Screening and Surveillance database 


\section{Table 3}

Frequency Table for Age Groups and Gender

\begin{tabular}{crr}
\hline Age Group & Male & Female \\
$50-54$ & $229(14 \%)$ & $19(25 \%)$ \\
$55-59$ & $258(15 \%)$ & $21(27 \%)$ \\
$60-64$ & $326(19 \%)$ & $18(23 \%)$ \\
$65-69$ & $302(18 \%)$ & $11(14 \%)$ \\
$70-75$ & $557(33 \%)$ & $8(10 \%)$ \\
Missing & $0(0 \%)$ & $0(0 \%)$ \\
\hline
\end{tabular}

Note. Due to rounding errors, column wise percentages may not equal $100 \%$.

\section{Table 4}

FIT Kits Returned Within 30 days. Two Proportions z-Test for the Difference between Pre and Post

\begin{tabular}{lrrrrr}
\hline Timeframe & Returned Kits & $n$ & Proportion & $S D$ & $S E$ \\
Pre & 36 & 216 & 0.17 & 0.37 & 0.03 \\
Post & 39 & 189 & 0.21 & 0.40 & 0.03 \\
\hline
\end{tabular}

Note. $z=-1.02, p=.307,95 \%$ CI: $[-0.12,0.04]$

\section{Table 5}

Compliance with Patient Teaching Documentation Pre and Post. Two Proportions z-Test for the Difference between Pre and Post

\begin{tabular}{lrrrrr}
\hline Timeframe & Pt Teaching - Yes & $n$ & Proportion & $S D$ & $S E$ \\
Pre & 15 & 53 & 0.28 & 0.45 & 0.06 \\
Post & 39 & 51 & 0.76 & 0.42 & 0.06 \\
\hline
\end{tabular}

Note. $z=-5.62, p<.001,95 \% \mathrm{CI}:[-0.65,-0.31]$

\section{Table 6}

Colorectal Cancer Screening and Surveillance Database Usage Per Month. Two Proportions z-Test for the Difference between Pre and Post

\begin{tabular}{lrrrrr}
\hline Timeframe & Usage - Yes & $n$ & Proportion & $S D$ & $S E$ \\
Pre & 11 & 19 & 0.58 & 0.49 & 0.11 \\
Post & 10 & 14 & 0.71 & 0.45 & 0.12 \\
\hline
\end{tabular}

Note. $z=-0.82, p=.414,95 \%$ CI: $[-0.46,0.19]$ 


\section{Figure 1}

PRISMA Literature Search Strategy Diagram

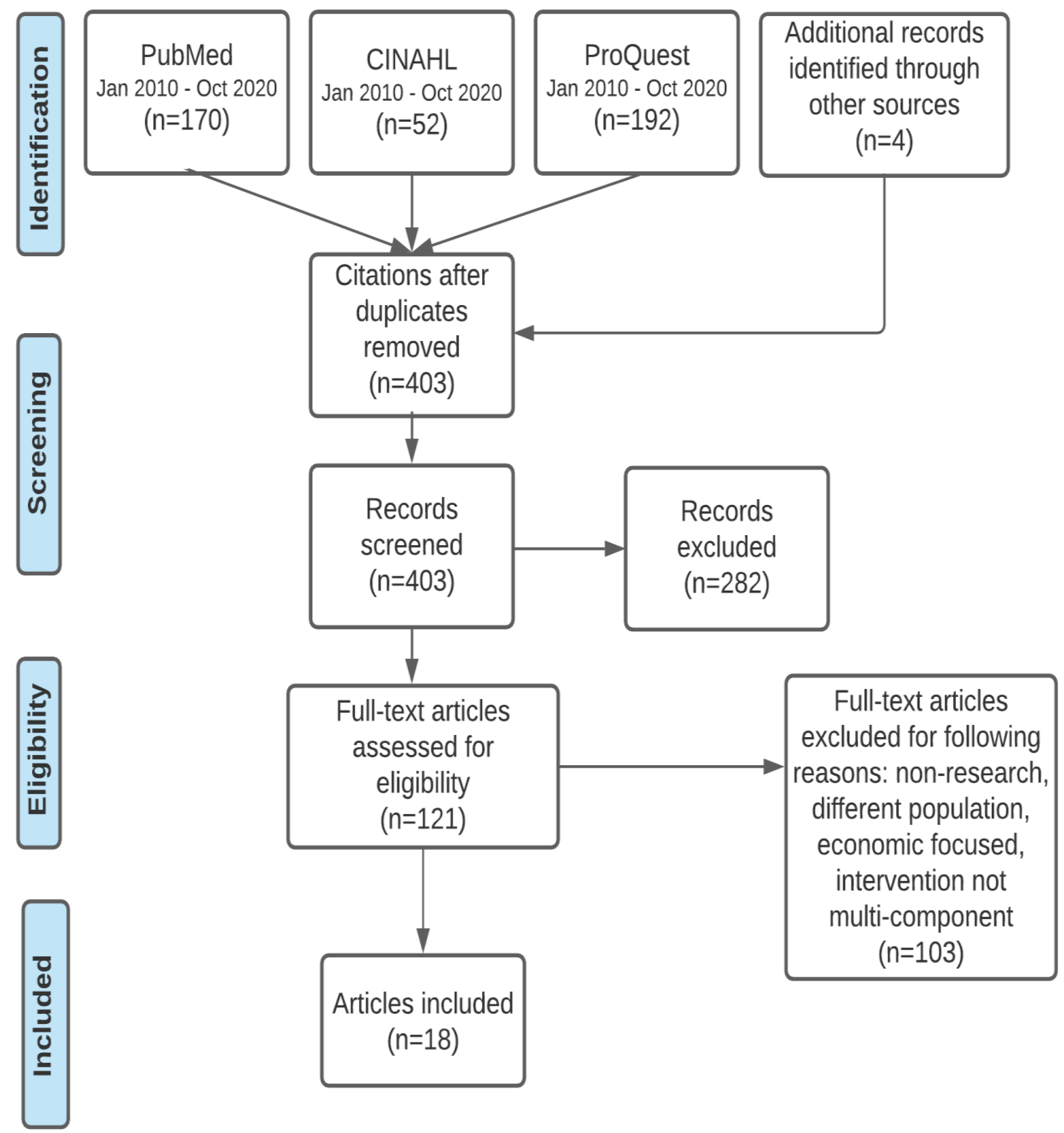

Note. Adapted from Moher, D., Liberati, A., Tetzlaff, J., \& Altman, D. G. The PRISMA Group (2009). Preferred Reporting Items for Systematic Reviews and Meta-Analyses: The PRISMA Statement. PLOS Medicine, 6(7), e1000097. https://doi.org/10.1371/journal.pmed.1000097 (Moher et al., 2009) 


\section{Figure 2}

Johns Hopkins Nursing Evidence-Based Practice Evidence Strength Rating

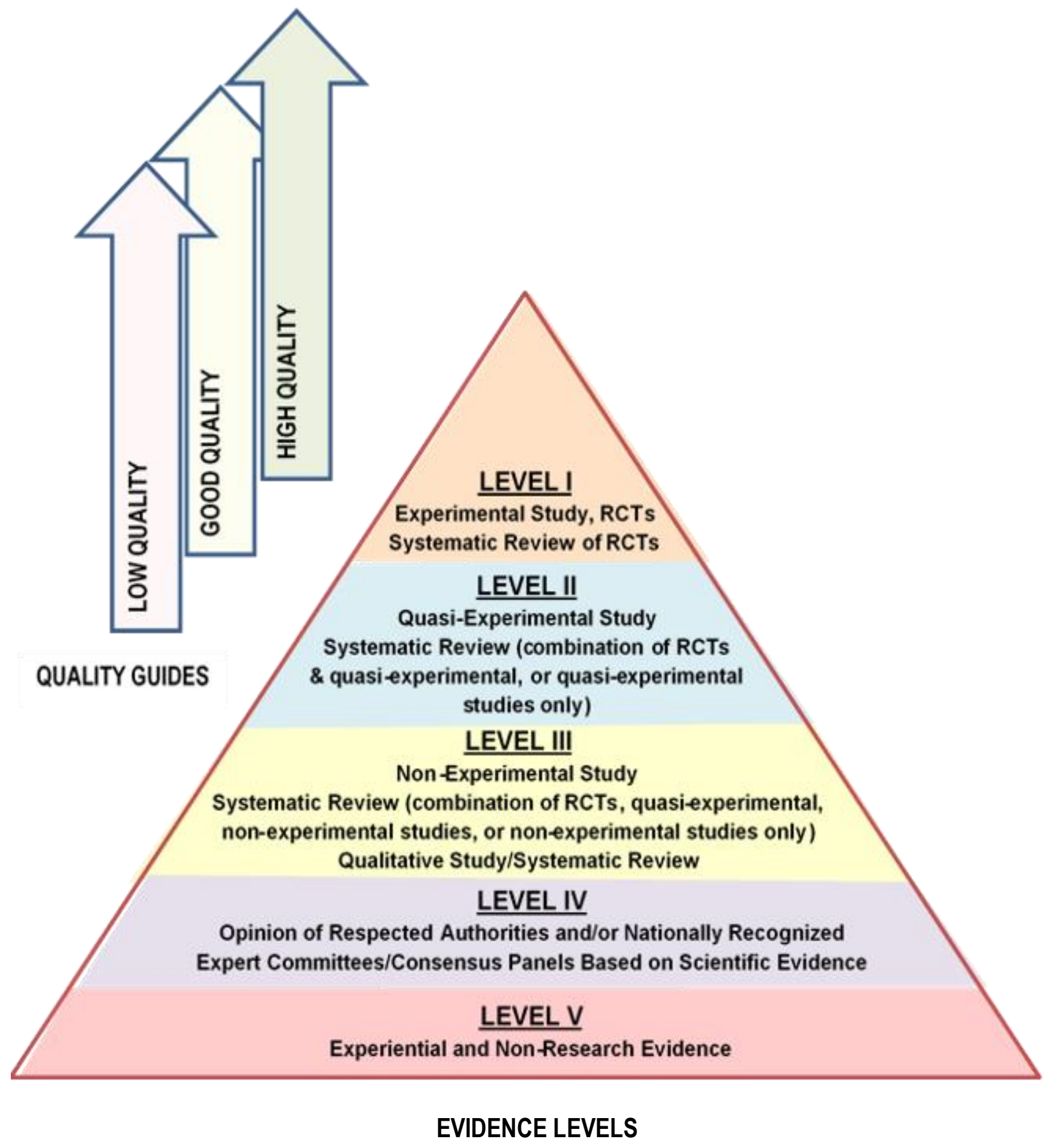

Note. Adapted from: Dang, D., \& Dearholt, S. L. (2017). Johns Hopkins nursing evidence-based practice: Model and guidelines (3rd ed.). Sigma Theta Tau International. 


\section{Figure 3}

Analytic Framework: Multi-component Interventions to Promote Breast, Cervical, and Colorectal Cancer Screening

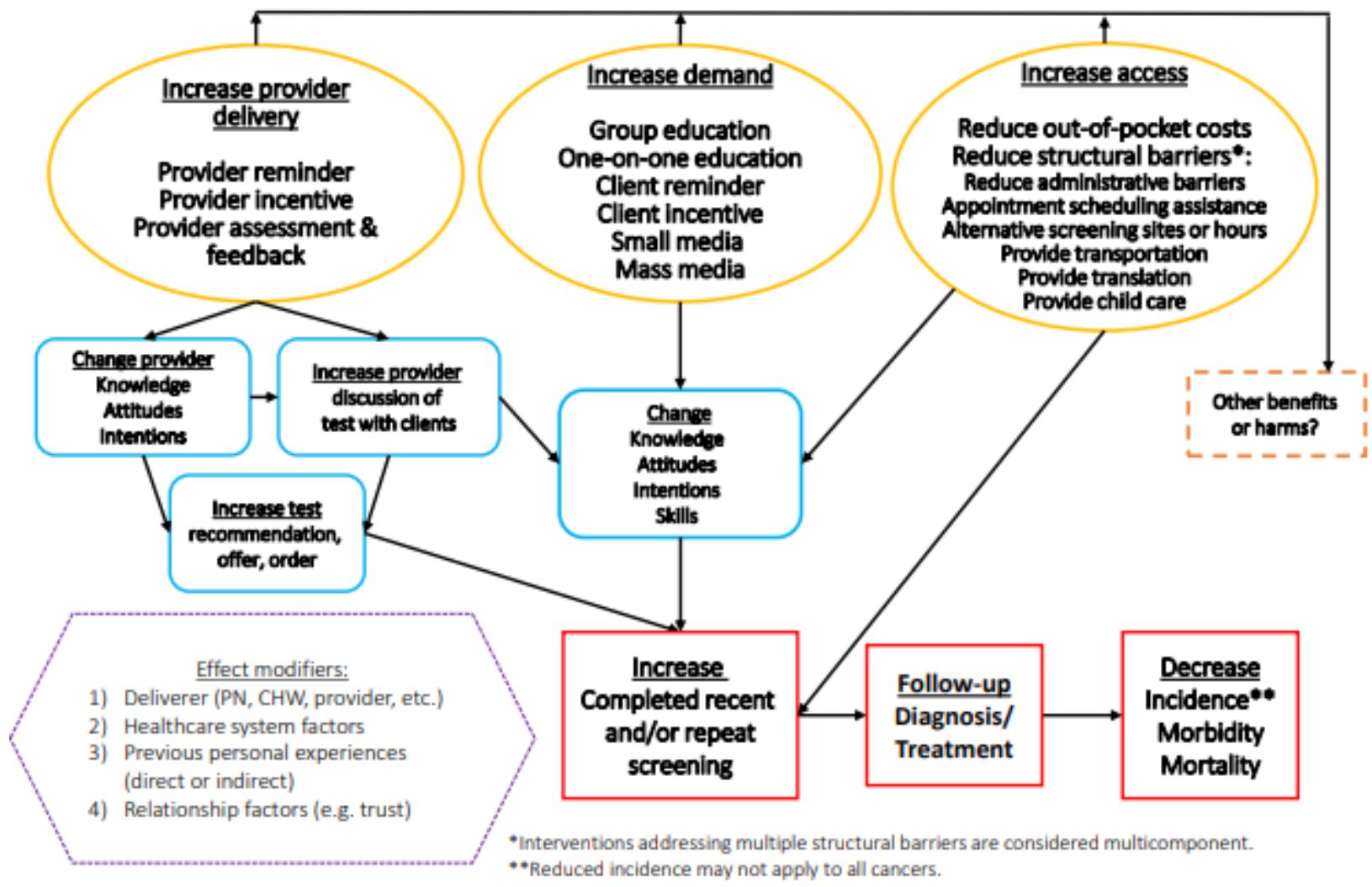

Note. From: U.S. Department of Health and Human Services. (2020). Cancer screening:

Multicomponent interventions - Colorectal cancer. https://www.thecommunityguide.org/findings/ cancer-screening-multicomponent-interventions-colorectal-cancer 


\section{Figure 4}

Percent of FIT Kits Returned Pre and Post Intervention

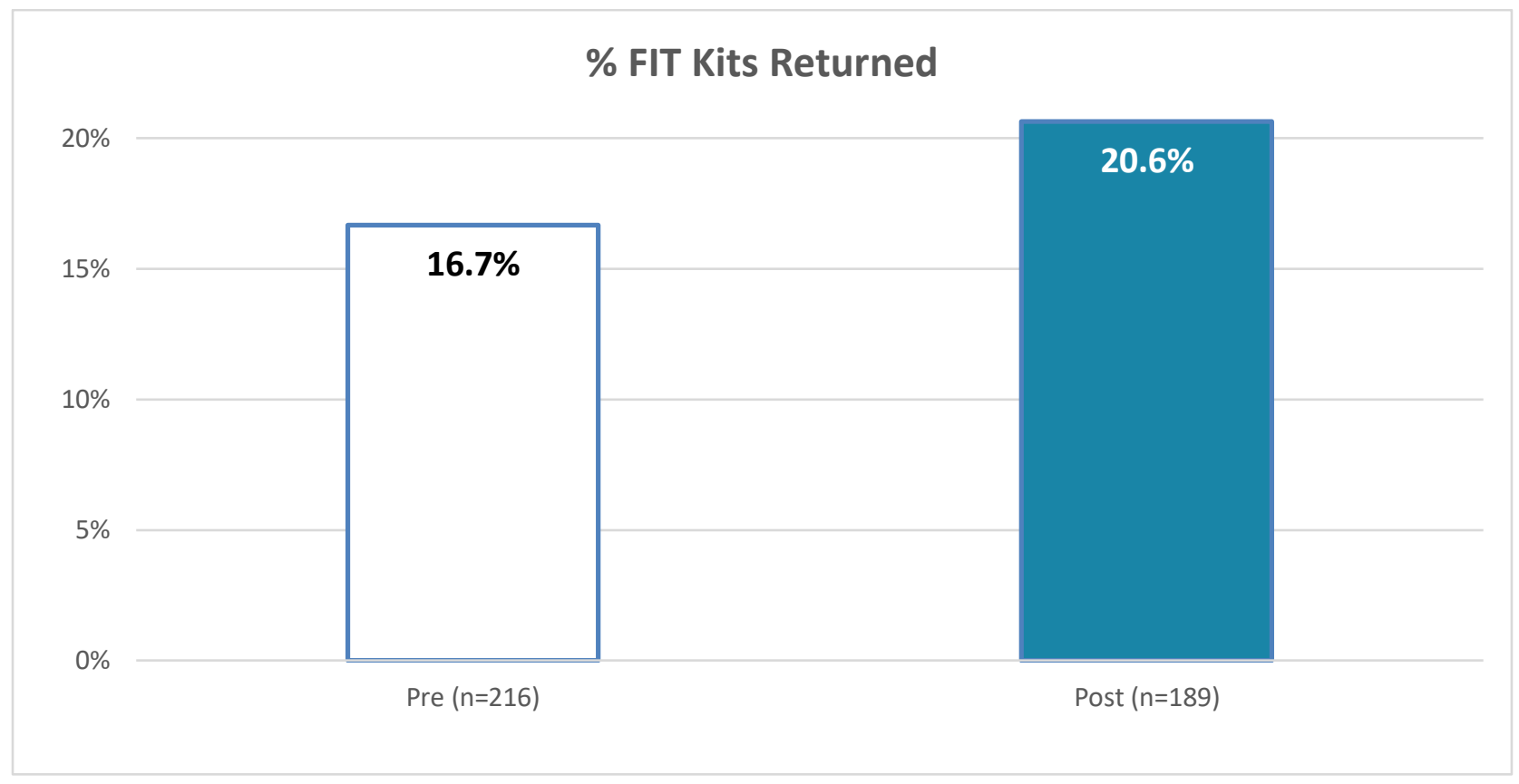

Figure 5

Mean Number of Positive FIT Test Patients Pending Follow Up Greater than 30 days

Mean No. of FIT + Pts Waiting Follow-up > 30 days

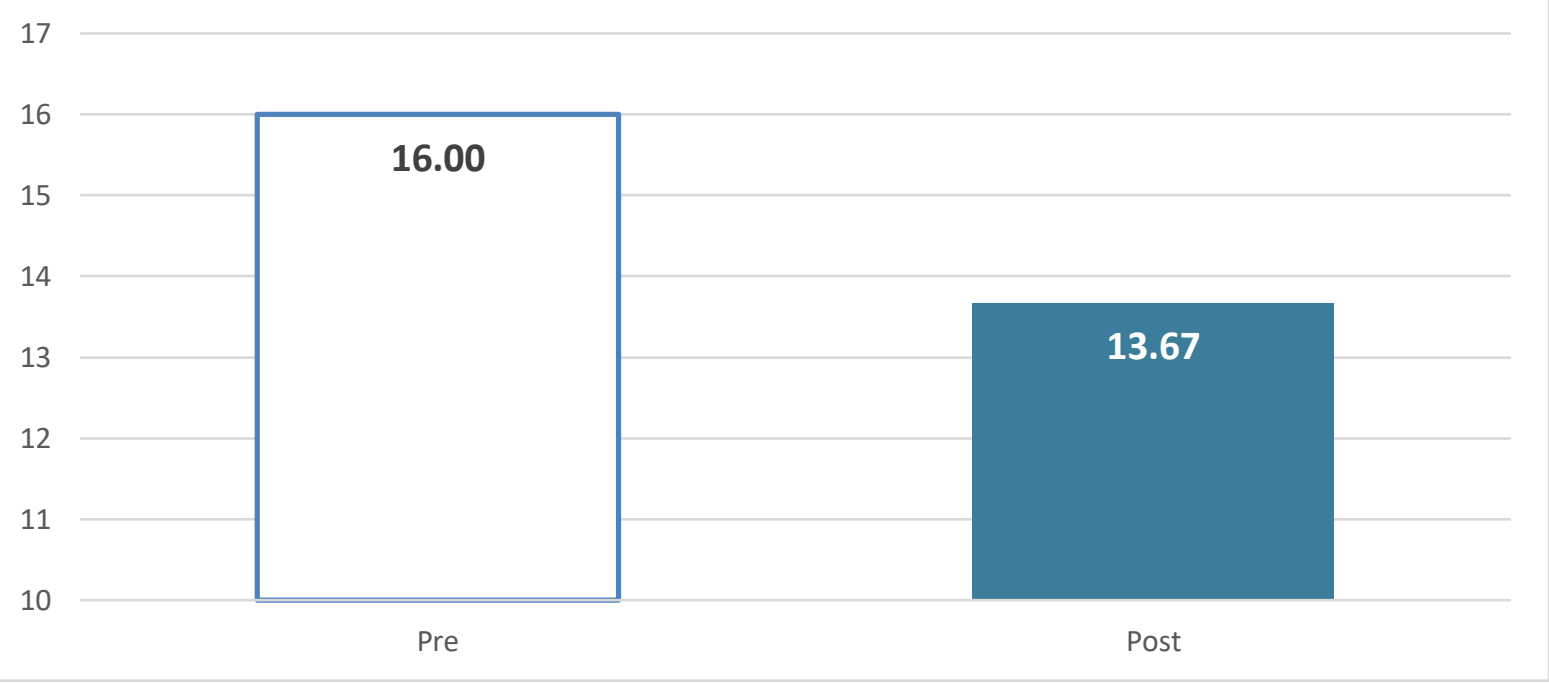




\section{Figure 6}

Total Number of FIT Positive Patients Pending Follow Up Greater than 30 days by Each Clinic

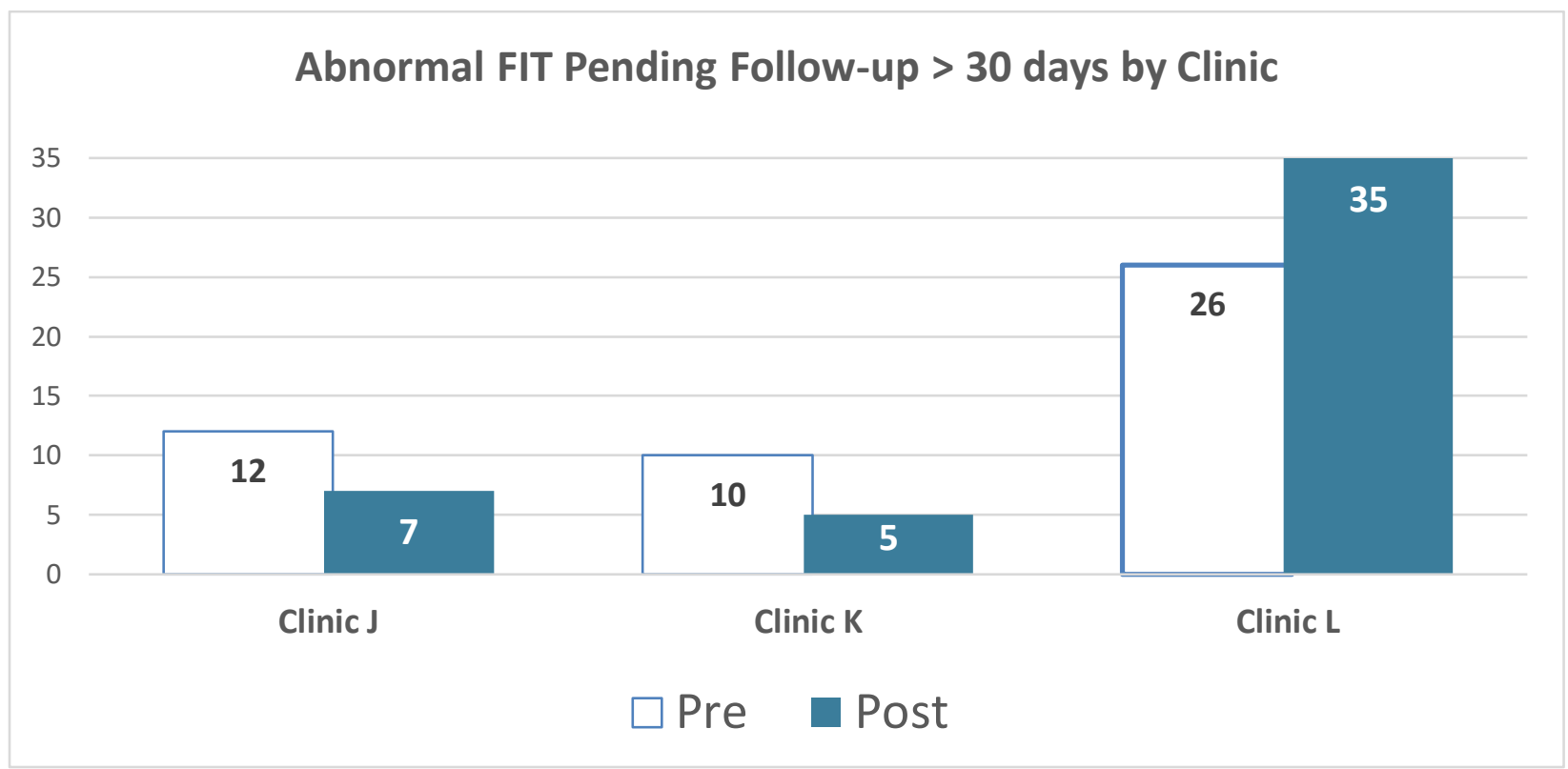

Figure 7

Mean Number of Patients Overdue for a Colorectal Cancer Screening in the Intervention Clinics

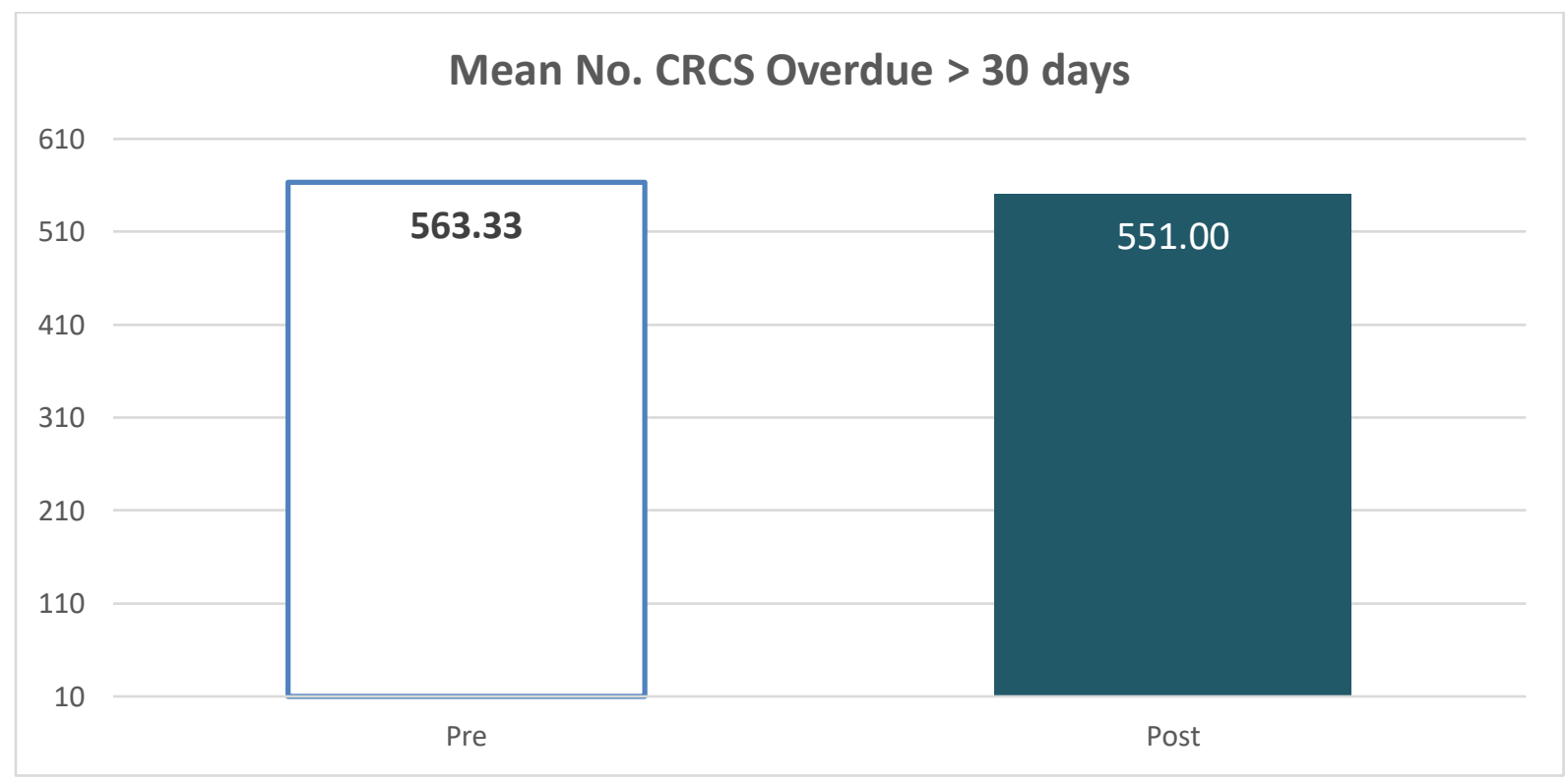




\section{Figure 8}

Nursing Documentation Compliance with Documentation of Patient Teaching

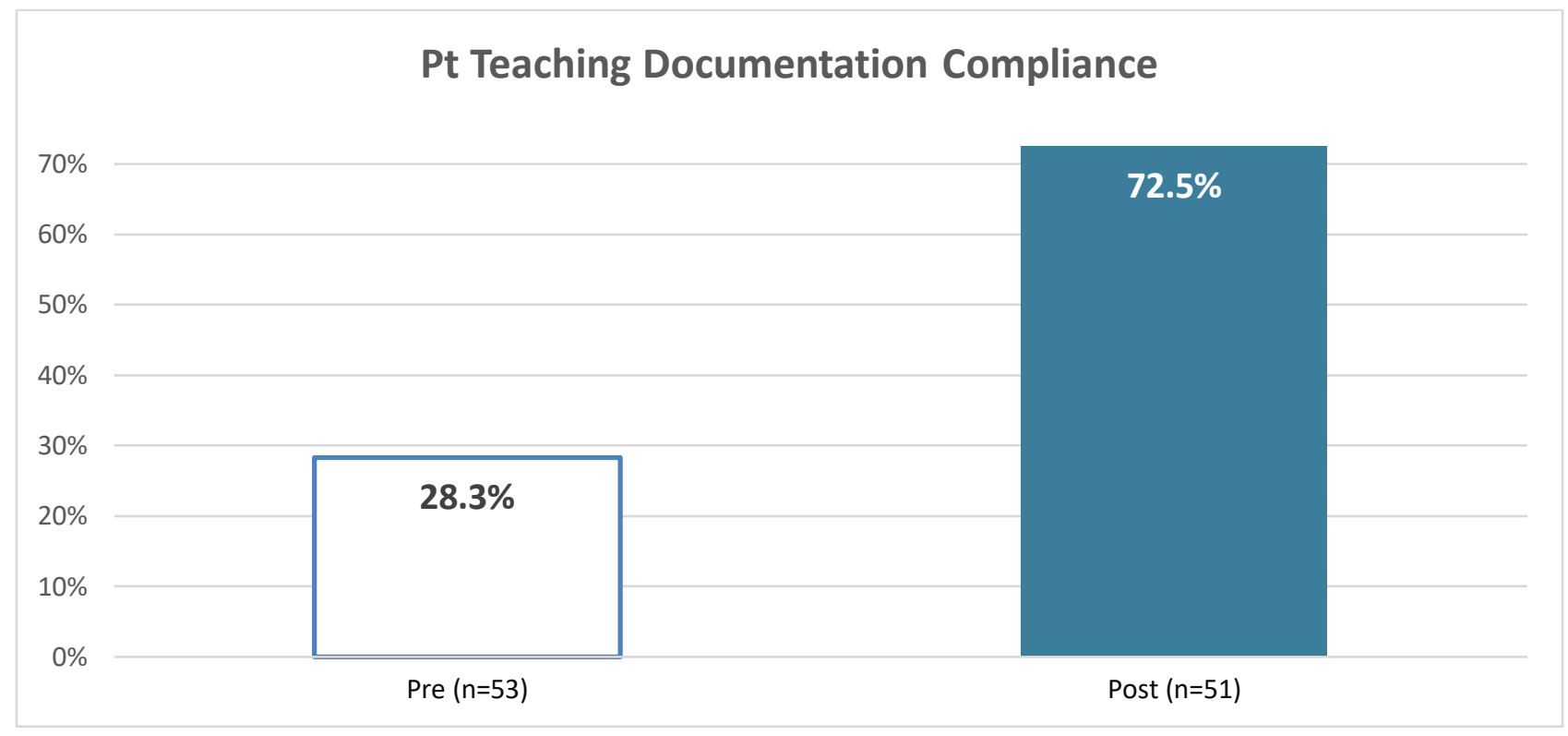

Figure 9

Overtime Nursing Hours

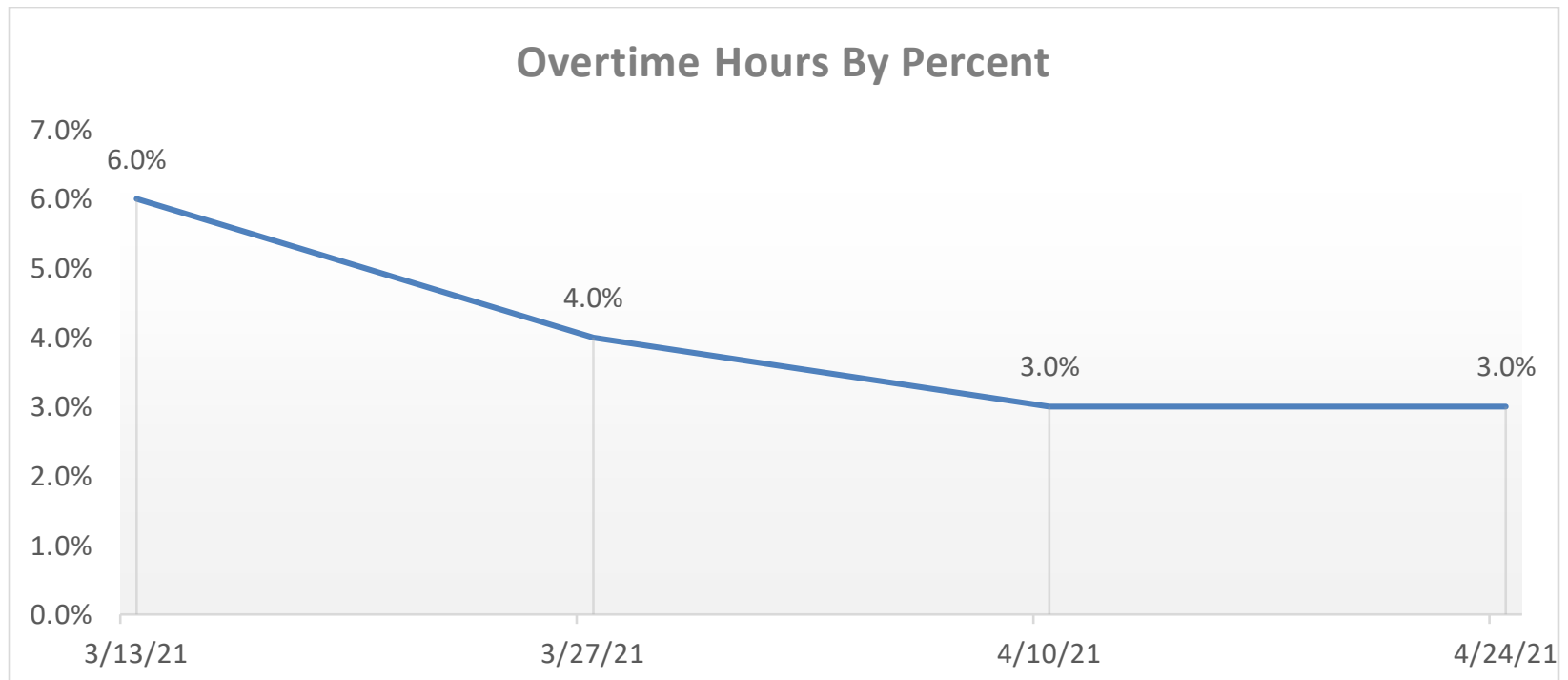




\section{Figure 10}

CRCS and Surveillance Database Use by Nursing Staff

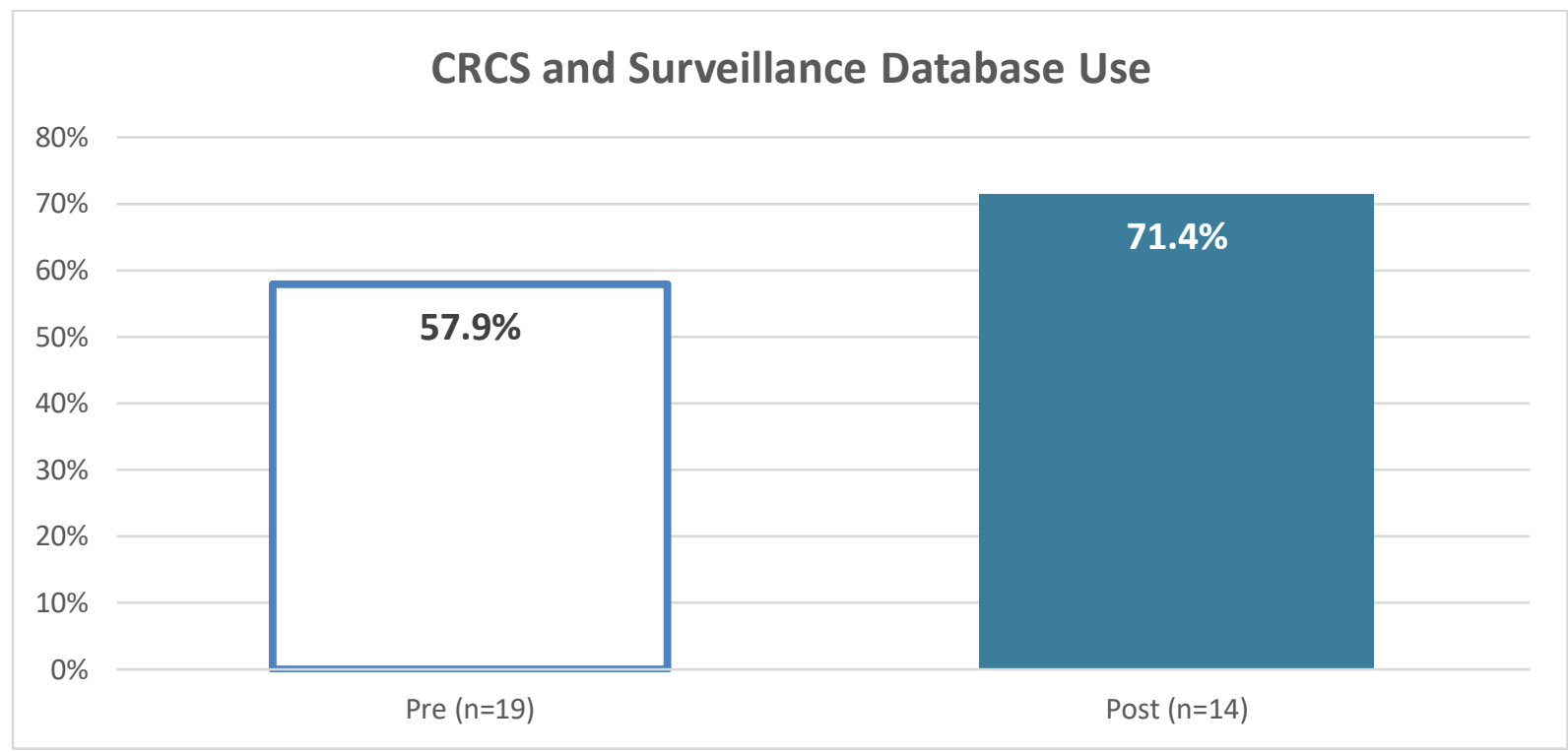




\section{Appendix A}

\section{Summary of Primary Research Evidence}

\begin{tabular}{|c|c|c|c|c|c|c|}
\hline Citation & $\begin{array}{c}\text { Design } \\
\text { Level } \\
\text { Quality } \\
\text { Grade }\end{array}$ & $\begin{array}{c}\text { Sample } \\
\text { Sample size }\end{array}$ & $\begin{array}{l}\text { Intervention } \\
\text { Comparison }\end{array}$ & $\begin{array}{l}\text { Theoretical } \\
\text { Foundation }\end{array}$ & $\begin{array}{c}\text { Outcome } \\
\text { Definition }\end{array}$ & $\begin{array}{c}\text { Usefulness } \\
\text { Results } \\
\text { Key Findings }\end{array}$ \\
\hline $\begin{array}{l}\text { Baker, D. W., Brown, } \\
\text { T., Buchanan, D. R., } \\
\text { Weil, J., Balsley, K., } \\
\text { Ranalli, L., Lee, J. Y., } \\
\text { Cameron, K. A., } \\
\text { Ferreira, M. R., } \\
\text { Stephens, Q., Goldman, } \\
\text { S. N., Rademaker, A., \& } \\
\text { Wolf, M. S. (2014). } \\
\text { Comparative } \\
\text { effectiveness of a } \\
\text { multifaceted } \\
\text { intervention to improve } \\
\text { adherence to annual } \\
\text { colorectal cancer } \\
\text { screening in community } \\
\text { health centers: A } \\
\text { randomized clinical trial. } \\
\text { JAMA Internal } \\
\text { Medicine, 174(8), 1235. } \\
\text { https://doi.org/10.1001/j } \\
\text { amainternmed.2014.235 } \\
2\end{array}$ & $\begin{array}{l}\text { RCT } \\
\text { Level I } \\
\text { Grade A }\end{array}$ & $\begin{array}{l}\text { Adult patients aged } 51 \\
\text { to } 75 \text { of community } \\
\text { health centers in } \\
\text { Chicago } \\
\text { Intervention group } \\
(n=202) \\
\text { Control group }(n=225)\end{array}$ & $\begin{array}{l}\text { Study: impact of multifaceted intervention } \\
\text { on increases FOBT adherence } \\
\text { Intervention: } \\
\text { Intervention group = usual care and mailed } \\
\text { reminder letter, FIT kit with low-literacy } \\
\text { instructions, postage-paid return envelope, } \\
\text { auto-phone message, and text message } \\
\text { when due for screening and } 2 \text { weeks later } \\
\text { if not done. If still not returned } 3 \text { months } \\
\text { later, phone call from CRC screening } \\
\text { navigator } \\
\text { Comparison: } \\
\text { Usual care = computerized reminders, } \\
\text { standing orders for medical assistants to } \\
\text { give patients home FIT and clinician } \\
\text { feedback on CRC screening rates }\end{array}$ & $\begin{array}{l}\text { Not stated - } \\
\text { approach consistent } \\
\text { with health literacy } \\
\text { framework. In order } \\
\text { to make informed } \\
\text { decisions about risks } \\
\text { and health } \\
\text { promotion and } \\
\text { illness prevention, } \\
\text { health literacy is an } \\
\text { essential component } \\
\text { (Woudstra et al., } \\
\text { 2019). }\end{array}$ & $\begin{array}{l}\text { Completion } \\
\text { of FOBT }\end{array}$ & $\begin{array}{l}\text { Intervention group } \\
\text { significantly higher than } \\
\text { control }(82.2 \% \text { vs } 37.3 \% \text {; } \\
\mathrm{P}<.001) \text {. } \\
\text { Giving FIT cards with } \\
\text { additional interventions } \\
\text { increases adherence to } \\
\text { CRCS in low literacy } \\
\text { groups. }\end{array}$ \\
\hline $\begin{array}{l}\text { Basch, C. E., Zybert, P., } \\
\text { Wolf, R. L., Basch, C. } \\
\text { H., Ullman, R., } \\
\text { Shmukler, C., King, F., } \\
\text { Neugut, A. I., \& Shea, S. } \\
\text { (2015). A randomized } \\
\text { trial to compare } \\
\text { alternative educational } \\
\text { interventions to increase }\end{array}$ & $\begin{array}{l}\text { Randomized } \\
\text { Trial (no } \\
\text { control) } \\
\text { Quasi- } \\
\text { experimental } \\
\text { Level II }\end{array}$ & $\begin{array}{l}\text { Adults, aged } 50-75 \\
\text { union members in New } \\
\text { York } \\
3 \text { arms: } \\
\text { Arm 1: Patient } \\
\text { education materials } \\
(\mathrm{PEM}) \text { group }(\mathrm{n}=180)\end{array}$ & $\begin{array}{l}\text { Study: determine impact of educational } \\
\text { interventions on CRCS rates } \\
\text { Study dates: } 2011 \text { and } 2013 . \\
3 \text { arms compared to each other. No control. } \\
\text { Arm 1: PEM - mailed printed }\end{array}$ & $\begin{array}{l}\text { Not stated but } \\
\text { interventions point } \\
\text { to a theoretical } \\
\text { foundation in the } \\
\text { socioecological } \\
\text { model (Gili et al., } \\
\text { 2006). }\end{array}$ & $\begin{array}{l}\text { CRCS: } \\
\text { colonoscopy, } \\
\text { FS and } \\
\text { FOBT or FIT }\end{array}$ & $\begin{array}{l}\text { TTE/PCP-AD vs PEM - } \\
\text { did not reach statistically } \\
\text { significant but trend } \\
\text { towards significance } \\
\text { (p=0.11). Could be } \\
\text { clinically significant even } \\
\text { though did not meet } \\
\text { statistical significance. }\end{array}$ \\
\hline
\end{tabular}




\begin{tabular}{|c|c|c|c|c|c|c|}
\hline Citation & $\begin{array}{l}\text { Design } \\
\text { Level } \\
\text { Quality } \\
\text { Grade }\end{array}$ & $\begin{array}{c}\text { Sample } \\
\text { Sample size }\end{array}$ & $\begin{array}{l}\text { Intervention } \\
\text { Comparison }\end{array}$ & $\begin{array}{l}\text { Theoretical } \\
\text { Foundation }\end{array}$ & $\begin{array}{c}\text { Outcome } \\
\text { Definition }\end{array}$ & $\begin{array}{c}\text { Usefulness } \\
\text { Results } \\
\text { Key Findings }\end{array}$ \\
\hline $\begin{array}{l}\text { colorectal cancer } \\
\text { screening in a hard-to- } \\
\text { reach urban minority } \\
\text { population with health } \\
\text { insurance. Journal of } \\
\text { Community Health, } \\
40(5), 975-983 \text {. } \\
\text { https://doi.org/10.1007/s } \\
10900-015-0021-5\end{array}$ & Grade B & $\begin{array}{l}\text { Arm 2: Providers - } \\
\text { academic detailing } \\
(\mathrm{PCP}-\mathrm{AD})(\mathrm{n}=185) \\
\text { Arm 3: Telephone } \\
\text { tailored education + } \\
\text { physician academic } \\
\text { detailing }(\mathrm{TTE} / \mathrm{PCP}- \\
\text { AD) }(\mathrm{n}=199)\end{array}$ & $\begin{array}{l}\text { education on CRC risk factors, early } \\
\text { detection and prevention. Information } \\
\text { colonoscopy, prep, other screenings } \\
\text { (FOBT, FIT, sigmoidoscopy, barium } \\
\text { enema and virtual colonoscopy) } \\
\text { Arm 2: PCP-AD - Primary care physicians } \\
\text { - academic detailing. Included targeted } \\
\text { education intervention about CRC } \\
\text { screening with physician's committing to } \\
\text { trying one new thing to improve CRC } \\
\text { screening practices } \\
\text { Arm 3: TTE/PCP-AD - primary care } \\
\text { physicians received same academic } \\
\text { detailing as arm } 2 \text { plus the addition of } \\
\text { tailored telephone education to patients }\end{array}$ & & & $\begin{array}{l}\text { TTE/PCP-AD had higher } \\
\text { adherence vs PEM in } \\
\text { ages }>60(27.3 \% \text { vs } \\
7.7 \% ; \mathrm{p}=.02) \\
\text { No statistical difference } \\
\text { between the three groups. }\end{array}$ \\
\hline $\begin{array}{l}\text { Chou, C.-K., Chen, S. } \\
\text { L.-S., Yen, A. M.-F., } \\
\text { Chiu, S. Y.-H., Fann, J. } \\
\text { C.-Y., Chiu, H.-M., } \\
\text { Chuang, S.-L., Chiang, } \\
\text { T.-H., Wu, M.-S., Wu, } \\
\text { C.-Y., Chia, S.-L., Lee, } \\
\text { Y.-C., Chiou, S.-T., \& } \\
\text { Chen, H.-H. (2016). } \\
\text { Outreach and inreach } \\
\text { organized service } \\
\text { screening programs for } \\
\text { colorectal cancer. PloS } \\
\text { One, 11(5). } \\
\text { https://doi.org/10.1371/j } \\
\text { ournal.pone.0155276 }\end{array}$ & $\begin{array}{l}\text { Quasi- } \\
\text { experimental } \\
\text { Pre-Post } \\
\text { cross- } \\
\text { sectional } \\
\text { design } \\
\text { Level II } \\
\text { Grade A }\end{array}$ & $\begin{array}{l}\text { Cross-sectional study } \\
\text { A total of } 3,363,896 \\
\text { subjects, adults aged, } \\
50-69 \text { in Taiwan } \\
2004 \text { to } 2009- \\
\text { Outreach only } \\
(n=1,160,895) \\
2010 \text { to } 2013 \text { - added } \\
\text { In-reach to Outreach } \\
(n=2,203,001)\end{array}$ & $\begin{array}{l}\text { Study to determine the impact of } \\
\text { integrating two national interventions on } \\
\text { CRCS and cancer detection } \\
\text { Interventions were compared to each other. } \\
\text { Outreach program = distribution of FIT } \\
\text { kits through the Taiwan districts } \\
\text { In-reach program = CRCS awareness } \\
\text { campaign via posters or video tapes in } \\
\text { hospital or clinic waiting rooms, } \\
\text { encouraging CRCS. Physicians and nurses } \\
\text { encouraged screenings. When FITs showed } \\
\text { positive, confirmatory diagnostic } \\
\text { procedures arranged by MDs. }\end{array}$ & $\begin{array}{l}\text { Not stated but the } \\
\text { study approach is } \\
\text { consistent to the } \\
\text { public health model } \\
\text { (White et al., 2019) }\end{array}$ & $\begin{array}{l}\text { Number of } \\
\text { CRCS and } \\
\text { CRC } \\
\text { detected }\end{array}$ & $\begin{array}{l}\text { Screenings increased } \\
\text { from } 21.4 \% \text { period } 1 \text { to } \\
36.9 \% \text { period } 2 \text { (P < } \\
0.01) \text {. } \\
\text { CRC detection (percent } \\
\text { of patients) - period } 1= \\
0.20 \% \text {; period } 2 \text { CRC } \\
0.34 \%(\mathrm{P}<0.01) \\
\text { Huge cohort - } \\
\text { demonstrates adding } \\
\text { layers to interventions } \\
\text { increases screenings } \\
\text { which result in higher } \\
\text { detection of CRC. } \\
\text { Limited generalizability } \\
\text { due to homogenous } \\
\text { population. }\end{array}$ \\
\hline
\end{tabular}




\begin{tabular}{|c|c|c|c|c|c|c|}
\hline Citation & $\begin{array}{l}\text { Design } \\
\text { Level } \\
\text { Quality } \\
\text { Grade }\end{array}$ & $\begin{array}{c}\text { Sample } \\
\text { Sample size }\end{array}$ & $\begin{array}{l}\text { Intervention } \\
\text { Comparison }\end{array}$ & $\begin{array}{l}\text { Theoretical } \\
\text { Foundation }\end{array}$ & $\begin{array}{l}\text { Outcome } \\
\text { Definition }\end{array}$ & $\begin{array}{c}\text { Usefulness } \\
\text { Results } \\
\text { Key Findings }\end{array}$ \\
\hline $\begin{array}{l}\text { Coronado, G. D., Petrik, } \\
\text { A. F., Vollmer, W. M., } \\
\text { Taplin, S. H., Keast, E. } \\
\text { M., Fields, S., \& Green, } \\
\text { B. B. (2018). } \\
\text { Effectiveness of a } \\
\text { mailed colorectal cancer } \\
\text { screening outreach } \\
\text { program in community } \\
\text { health clinics: The } \\
\text { STOP CRC cluster } \\
\text { randomized clinical trial. } \\
\text { JAMA Internal } \\
\text { Medicine, 178(9), 1174- } \\
1181 . \\
\text { https://doi.org/10.1001/j } \\
\text { amainternmed.2018.362 } \\
9\end{array}$ & $\begin{array}{l}\text { RCT } \\
\text { Level I } \\
\text { Grade A }\end{array}$ & $\begin{array}{l}\text { Adult patients, aged 50- } \\
74, \text { receiving care at a } \\
\text { Federally Qualified } \\
\text { Health Centers in } \\
\text { Oregon and California } \\
\text { Clinics randomized to } \\
\text { intervention or control } \\
\text { Intervention clinics } \\
(\mathrm{n}=13 \text { clinics). Eligible } \\
\text { patients = 21,134 } \\
\text { Control - Usual care } \\
\text { (n=13 clinics). Eligible } \\
\text { patients = 20,059 }\end{array}$ & $\begin{array}{l}\text { Study to determine effectiveness of } \\
\text { electronic health record-embedded mailed } \\
\text { FIT tests with adherence to CRCS } \\
\text { Study dates: February, } 2014 \text { and August, } \\
2015 \\
\text { Intervention: Three sequential mailings: } \\
\text { (1) introductory letter; (2) a FIT kit packet } \\
\text { with instructions (3) a reminder letter. } \\
\text { Comparison: } \\
\text { Usual care = standard processes for CRCS } \\
=\text { providing information and ordering tests } \\
\text { during routine clinical encounters. }\end{array}$ & $\begin{array}{l}\text { Not stated but the } \\
\text { study approach is } \\
\text { consistent with the } \\
\text { health promotion } \\
\text { model where the } \\
\text { goal is to prevent } \\
\text { illness and promote } \\
\text { wellness (Johns et } \\
\text { al., 1987) }\end{array}$ & $\begin{array}{l}\text { Completion } \\
\text { of FIT } \\
\text { Secondary }= \\
\text { proportion } \\
\text { who } \\
\text { completed } \\
\text { any CRCS } \\
\text { (FOBT, FS, } \\
\text { colonoscopy) }\end{array}$ & $\begin{array}{l}\text { FIT completion } \\
\text { proportions }=3.4 \\
\text { percentage points higher } \\
\text { for intervention clinics } \\
(13.9 \%) \text { than usual care } \\
\text { clinics }(10.4 \%)(95 \% \text { CI, } \\
0.1 \%-6.8 \% ; \mathrm{P}=.05) . \\
\text { Any CRCS = } 3.8 \\
\text { percentage points higher } \\
\text { for intervention clinics } \\
(18.3 \%) \text { than for usual } \\
\text { care clinics }(14.5 \%) \\
(95 \% \text { CI, } 0.6 \%-7.0 \% ; \mathrm{P}= \\
.02) .\end{array}$ \\
\hline \begin{tabular}{|l|} 
Davis, S. N., Christy, S. \\
M., Chavarria, E. A., \\
Abdulla, R., Sutton, S. \\
K., Schmidt, A., \\
Vadaparampil, S. T., \\
Quinn, G. P., Simmons, \\
V. N., Ufondu, C., \\
Ravindra, C., Schultz, I., \\
Roetzheim, R., Shibata, \\
D., Meade, C. D., \& \\
Gwede, C. K. (2017). A \\
randomized controlled \\
trial of a multi- \\
component targeted low- \\
literacy educational \\
intervention compared \\
with a non-targeted \\
intervention to boost \\
colorectal cancer
\end{tabular} & $\begin{array}{l}\text { RCT } \\
\text { Level } 1 \\
\text { Grade A }\end{array}$ & $\begin{array}{l}\text { Adult patients aged 50- } \\
75 \text { years, of a Federally } \\
\text { Qualified Health Center } \\
\text { or a primary care } \\
\text { community health } \\
\text { clinic in Tampa Bay } \\
\text { area } \\
\text { Intervention }(n=210) \\
\text { Control - Usual care } \\
(n=207)\end{array}$ & $\begin{array}{l}\text { Study aim: determine impact of } \\
\text { intervention to usual care and impact of } \\
\text { sociodemographic and health-related } \\
\text { beliefs on adherence FIT screening } \\
\text { Conducted between July } 2012 \text { and August } \\
\text { 2014- Colorectal Cancer Awareness, } \\
\text { Research, Education and Screening } \\
\text { (CARES) trial } \\
\text { Intervention: } \\
\text { Usual care plus targeted low-literacy, } \\
\text { photonovella booklet and DVD. } \\
\text { Photonovella/DVD = local characters } \\
\text { modeled using FIT kit } \\
\text { Comparison: } \\
\text { Usual care written and verbal FIT kit } \\
\text { collection instructions, along with an in- }\end{array}$ & $\begin{array}{l}\text { Authors stated } \\
\text { theoretical } \\
\text { foundation = } \\
\text { Preventive Health } \\
\text { Model }\end{array}$ & $\begin{array}{l}\text { Returned FIT } \\
\text { kits }\end{array}$ & $\begin{array}{l}\text { FIT completion rate was } \\
81 \%, 78.1 \% \text { for } \\
\text { intervention vs. } \\
83.5 \% \text { for control } \\
(\mathrm{p}=0.17) \text {. } \\
\text { No significant difference } \\
\text { between the groups. } \\
\text { Control was slightly } \\
\text { higher. Simply providing } \\
\text { a DVD may not have } \\
\text { much impact. }\end{array}$ \\
\hline
\end{tabular}




\begin{tabular}{|c|c|c|c|c|c|c|}
\hline Citation & $\begin{array}{l}\text { Design } \\
\text { Level } \\
\text { Quality } \\
\text { Grade }\end{array}$ & $\begin{array}{c}\text { Sample } \\
\text { Sample size }\end{array}$ & $\begin{array}{l}\text { Intervention } \\
\text { Comparison }\end{array}$ & $\begin{array}{l}\text { Theoretical } \\
\text { Foundation }\end{array}$ & $\begin{array}{l}\text { Outcome } \\
\text { Definition }\end{array}$ & $\begin{array}{c}\text { Usefulness } \\
\text { Results } \\
\text { Key Findings }\end{array}$ \\
\hline \begin{tabular}{|l|} 
screening with fecal \\
immunochemical test in \\
community clinics. \\
Cancer, 123(8), 1390- \\
1400. \\
https://doi.org/10.1002/c \\
ncr.30481
\end{tabular} & & & $\begin{array}{l}\text { person FIT kit collection demonstration } \\
\text { and standard CDC brochure }\end{array}$ & & & \\
\hline $\begin{array}{l}\text { Dodd, N., Carey, M., } \\
\text { Mansfield, E., } \\
\text { Oldmeadow, C., \& } \\
\text { Evans, T.-J. (2019). } \\
\text { Testing the effectiveness } \\
\text { of a general practice } \\
\text { intervention to improve } \\
\text { uptake of colorectal } \\
\text { cancer screening: A } \\
\text { randomised controlled } \\
\text { trial. Australian and } \\
\text { New Zealand Journal of } \\
\text { Public Health, 43(5), } \\
\text { 464-469. } \\
\text { https://doi.org/10.1111/1 } \\
\text { 753-6405.12913 }\end{array}$ & $\begin{array}{l}\text { RCT } \\
\text { Level I } \\
\text { Grade C }\end{array}$ & $\begin{array}{l}\text { Adult patients aged, 50- } \\
74 \text { of four general } \\
\text { practices in New South } \\
\text { Wales, Australia } \\
\text { Intervention }(n=53) \\
\text { Control }(n=70)\end{array}$ & $\begin{array}{l}\text { Study to determine impact on FOBT } \\
\text { adherence at six-week follow-up and } \\
\text { impact in patient knowledge } \\
\text { Study dates: September } 2016 \text { to- May } \\
2017 \\
\text { Baseline knowledge assessment about } \\
\text { CRC. Assessment tool lacked validity or } \\
\text { reliability testing. } \\
\text { Intervention: Before the appointment, } \\
\text { patients received pre-paid FIT kit with } \\
\text { return postage; educational print-out about } \\
\text { the importance of CRCS. Information } \\
\text { reviewed at MD appointment } \\
\text { Comparison: } \\
\text { Usual care - patients received printed CRC } \\
\text { educational print-out. }\end{array}$ & $\begin{array}{l}\text { Not stated, but the } \\
\text { study approach is } \\
\text { consistent with the } \\
\text { health promotion } \\
\text { model where the } \\
\text { goal is to prevent } \\
\text { illness and promote } \\
\text { wellness (Johns et } \\
\text { al., 1987) }\end{array}$ & \begin{tabular}{l|} 
Primary \\
outcome = \\
self-reported \\
CRCS. \\
Secondary \\
outcome = \\
patient \\
knowledge.
\end{tabular} & $\begin{array}{l}\text { Intervention = } \\
\text { significantly higher self- } \\
\text { reported CRCS (OR } \\
10.24 ; 95 \%, \text { CI2.9-36.6, } \\
\mathrm{p}=0.0006) . \\
\text { No statistically } \\
\text { significant differences } \\
\text { between the intervention } \\
\text { and control on } \\
\text { knowledge. } \\
\text { (Control OR } 1.59(0.8 \text { to } \\
3.1) \text { p=0.18; Intervention } \\
\text { OR } 1.58 \text { ( } 0.5 \text { to } 4.9) \\
\text { p=0.43) } \\
\text { Generalizability limited } \\
\text { due to small sample size. }\end{array}$ \\
\hline \begin{tabular}{|l|} 
Fitzgibbon, M. L., \\
Ferreira, M. R., Dolan, \\
N. C., Davis, T. C., \\
Rademaker, A. W., \\
Wolf, M. S., Liu, D., \\
Gorby, N., Schmitt, B. \\
P., \& Bennett, C. L. \\
(2016). Process \\
evaluation in an \\
intervention designed to \\
improve rates of
\end{tabular} & $\begin{array}{l}\text { RCT } \\
\text { Level I } \\
\text { Grade A }\end{array}$ & $\begin{array}{l}\text { Male veteran patients, } \\
\text { aged } 50 \text { years and older } \\
\text { of VA primary clinics } \\
\text { in Chicago } \\
\text { Intervention clinic } \\
(\mathrm{n}=728 \text { patients }) \\
\text { Control clinic }- \text { Usual } \\
\text { care }(\mathrm{n}=258 \text { patients })\end{array}$ & $\begin{array}{l}\text { Study to determine impact of combined } \\
\text { intervention on screening } \\
\text { recommendations by providers and } \\
\text { adherence by patients } \\
\text { Patient intervention: } \\
\text { CRCS pamphlet; video for educating low- } \\
\text { literacy patients and a simplified FOBT } \\
\text { instructions. } \\
\text { Provider intervention: }\end{array}$ & $\begin{array}{l}\text { The authors } \\
\text { identified the Health } \\
\text { Belief Model as the } \\
\text { framework that } \\
\text { provided the } \\
\text { foundation for the } \\
\text { patient intervention } \\
\text { portion of the study. } \\
\text { They also identified } \\
\text { Deming's Quality } \\
\text { Improvement }\end{array}$ & \begin{tabular}{|l|} 
Primary \\
outcome \\
measures $=$ \\
CRCS (home \\
FOBT, FS, \\
or colon- \\
oscopy)
\end{tabular} & $\begin{array}{l}\text { Providers who attended } \\
\text { intervention sessions } \\
\text { recommended CRCS at a } \\
\text { higher rate during patient } \\
\text { visits compared to those } \\
\text { who did not attend } 64 \% \\
\text { vs } 54 \% \text { of visits }(\mathrm{p}<.01) \\
\text { Also, the patients of } \\
\text { providers who attended } \\
\text { intervention sessions }\end{array}$ \\
\hline
\end{tabular}




\begin{tabular}{|c|c|c|c|c|c|c|}
\hline Citation & $\begin{array}{l}\text { Design } \\
\text { Level } \\
\text { Quality } \\
\text { Grade }\end{array}$ & $\begin{array}{c}\text { Sample } \\
\text { Sample size }\end{array}$ & $\begin{array}{l}\text { Intervention } \\
\text { Comparison }\end{array}$ & $\begin{array}{l}\text { Theoretical } \\
\text { Foundation }\end{array}$ & $\begin{array}{l}\text { Outcome } \\
\text { Definition }\end{array}$ & $\begin{array}{l}\text { Usefulness } \\
\text { Results } \\
\text { Key Findings }\end{array}$ \\
\hline \begin{tabular}{|l|} 
colorectal cancer \\
screening in a VA \\
medical center. Health \\
Promotion Practice. \\
https://doi.org/10.1177/1 \\
524839907302210
\end{tabular} & & $\begin{array}{l}\text { Provider Intervention - } \\
\text { Attended some sessions } \\
(\mathrm{n}=37) \\
\text { Attended no sessions } \\
(\mathrm{n}=7)\end{array}$ & $\begin{array}{l}\text { One-hour feedback sessions every 4-6 } \\
\text { months with data about screening } \\
\text { performance }\end{array}$ & $\begin{array}{l}\text { framework as the } \\
\text { guiding framework } \\
\text { for the provider } \\
\text { intervention portion. }\end{array}$ & & $\begin{array}{l}\text { were more likely to be } \\
\text { screened }(42 \% \text { versus } \\
29 \%, p<.05) \\
\text { Patient intervention - no } \\
\text { difference in the } \\
\text { screening adherence } \\
\text { between intervention and } \\
\text { control }\end{array}$ \\
\hline $\begin{array}{l}\text { Fortuna, R. J., Idris, A., } \\
\text { Winters, P., Humiston, } \\
\text { S. G., Scofield, S., } \\
\text { Hendren, S., Ford, P., } \\
\text { Li, S. X. L., \& Fiscella, } \\
\text { K. (2014). Get screened: } \\
\text { A randomized trial of } \\
\text { the incremental benefits } \\
\text { of reminders, recall, and } \\
\text { outreach on cancer } \\
\text { screening. Journal of } \\
\text { General Internal } \\
\text { Medicine, 29(1), 90-97. } \\
\text { https://doi.org/10.1007/s } \\
\text { 11606-013-2586-y }\end{array}$ & $\begin{array}{l}\text { Randomized } \\
\text { Trial (No } \\
\text { control) } \\
\text { Quasi- } \\
\text { experimental } \\
\text { Level II } \\
\text { Grade A }\end{array}$ & $\begin{array}{l}\text { Adult patients, aged } \\
50-74 \text { years past due } \\
\text { for CRC screen and } \\
\text { women aged 40-74 } \\
\text { years past due for } \\
\text { breast cancer (BC) } \\
\text { screening receiving } \\
\text { care in a safety net } \\
\text { clinic in urban New } \\
\text { York. } \\
4 \text { arms: } \\
\text { Arm 1: Letter } \\
\text { (n=157) } \\
\text { Arm 2: Letter }+ \\
\text { Automated Call } \\
\text { (n=158) } \\
\text { Arm 3: Letter }+ \\
\text { Automated Call + } \\
\text { Paper Visit Prompt } \\
\text { (n=156) } \\
\text { Arm 4: Letter }+ \\
\text { Personal } \\
\text { Call (n=153) }\end{array}$ & $\begin{array}{l}\text { Study to determine impact of interventions } \\
\text { on colorectal and breast cancer screenings. } \\
\text { Parallel comparisons of } 4 \text { arms. } \\
\text { Interventions: } \\
\text { Arm 1: Letter - reminder letter for overdue } \\
\text { screening. } \\
\text { Arm 2: Letter + Automated call - same as } \\
\text { arm 1 plus up to } 5 \text { automated call } \\
\text { reminders } \\
\text { Arm 3: Letter + Automated call + Paper } \\
\text { Visit Prompt: Same as arm } 2 \text { plus addition } \\
\text { of education sheet encouraging screening } \\
\text { at the time of visit with the physician. } \\
\text { Arm 4: Letter + Personal call: Same letter } \\
\text { as arm } 1 \text { plus a call from a trained outreach } \\
\text { worker. }\end{array}$ & $\begin{array}{l}\text { Not stated. The } \\
\text { study approach is } \\
\text { consistent with a } \\
\text { theoretical } \\
\text { foundation in the } \\
\text { socioecological } \\
\text { model (Gili et al., } \\
\text { 2006). }\end{array}$ & $\begin{array}{l}\text { Cancer } \\
\text { screening = } \\
\text { mammo- } \\
\text { gram, CRCS } \\
\text { (FOBT, FIT, } \\
\text { FS, colon- } \\
\text { oscopy, } \\
\text { DCBE) }\end{array}$ & 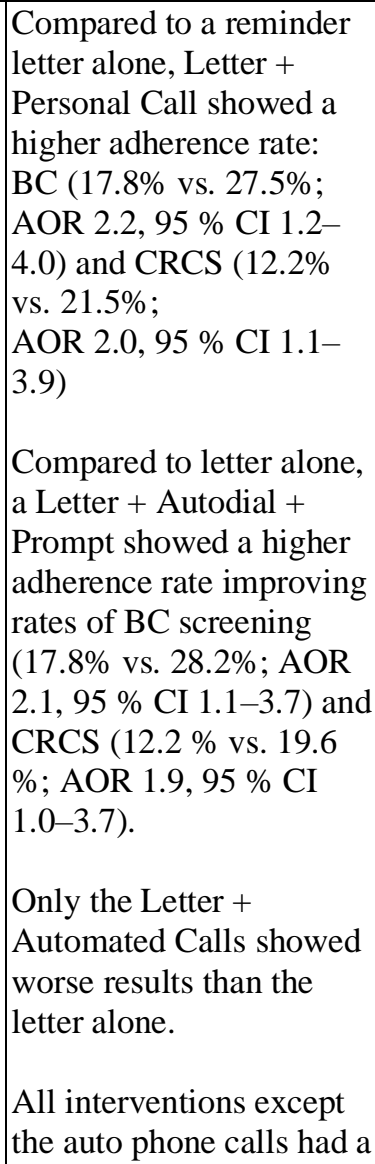 \\
\hline
\end{tabular}




\begin{tabular}{|c|c|c|c|c|c|c|}
\hline Citation & $\begin{array}{c}\text { Design } \\
\text { Level } \\
\text { Quality } \\
\text { Grade }\end{array}$ & $\begin{array}{c}\text { Sample } \\
\text { Sample size }\end{array}$ & $\begin{array}{l}\text { Intervention } \\
\text { Comparison }\end{array}$ & $\begin{array}{l}\text { Theoretical } \\
\text { Foundation }\end{array}$ & $\begin{array}{l}\text { Outcome } \\
\text { Definition }\end{array}$ & $\begin{array}{c}\text { Usefulness } \\
\text { Results } \\
\text { Key Findings }\end{array}$ \\
\hline & & & & & & $\begin{array}{l}\text { higher impact than a } \\
\text { letter alone in increasing } \\
\text { screening rates. }\end{array}$ \\
\hline $\begin{array}{l}\text { Green, B. B., Wang, C.- } \\
\text { Y., Anderson, M. L., } \\
\text { Chubak, J., Meenan, R. } \\
\text { T., Vernon, S. W., \& } \\
\text { Fuller, S. (2013). An } \\
\text { automated intervention } \\
\text { with stepped increases in } \\
\text { support to increase } \\
\text { uptake of colorectal } \\
\text { cancer screening: A } \\
\text { randomized trial. Annals } \\
\text { of Internal Medicine, } \\
\text { 158(5 Pt 1), 301-311. } \\
\text { https://doi.org/10.7326/0 } \\
\text { 003-4819-158-5- } \\
\text { 201303050-00002 }\end{array}$ & $\begin{array}{l}\text { RCT } \\
\text { Level I } \\
\text { Grade A }\end{array}$ & $\begin{array}{l}\text { Adult patients, aged 50 } \\
\text { to } 73 \text { years of primary } \\
\text { care clinics in } \\
\text { Washington state. } \\
4 \text { arms: } \\
\text { Arm 1: Usual Care plus } \\
\text { Automated Telephone } \\
\text { (UC/AT) (n=1173) } \\
\text { Arm 2: Usual Care Plus } \\
\text { Automated } \\
\text { Interventions Plus } \\
\text { Assisted Care } \\
\text { (UC/AT/AC) (n=1159) } \\
\text { Arm 3: Usual Care Plus } \\
\text { Automated } \\
\text { Interventions Plus } \\
\text { Assisted Interventions } \\
\text { Plus Navigated Care } \\
\text { (UC/RN) (n=1170) } \\
\text { Control: } \\
\text { Arm 4: Usual care } \\
\text { (UC) (n=1166) }\end{array}$ & $\begin{array}{l}\text { Study aim: determine impact of escalating } \\
\text { interventions on CRCS and screening } \\
\text { decisions. } \\
\text { Interventions: } \\
\text { Study took place between August } 2008 \text { and } \\
\text { November } 2009 \\
\text { Arm 1: UC/AT - sent reminder letters } \\
\text { informing due for CRCS; educational } \\
\text { pamphlet about different screening options. } \\
\text { Patients could request alternate screening } \\
\text { method or notified that FOBT kits were } \\
\text { coming. If no alternates selected patient } \\
\text { were mailed FOBT kits with postage-paid } \\
\text { return envelope. } \\
\text { Arm 2: UC/AT/AC - received everything } \\
\text { that UC/AT patients received plus } \\
\text { telephone assistance from a medical } \\
\text { assistant. } \\
\text { Arm 3: UC/RN - received all items as Arm } \\
2 \text { with addition of RN Navigators } \\
\text { Comparison: } \\
\text { Arm 4: UC - patients received mailings of } \\
\text { evidence-based guidelines; patient } \\
\text { handouts; and an annual systems-delivered, } \\
\text { patient-tailored "birthday letter" with } \\
\text { previous completion and due dates for } \\
\text { immunizations and screening tests }\end{array}$ & $\begin{array}{l}\text { Not stated. The } \\
\text { multiple } \\
\text { interventions } \\
\text { approach is } \\
\text { consistent with a } \\
\text { theoretical } \\
\text { foundation in the } \\
\text { socioecological } \\
\text { model (Gili et al., } \\
\text { 2006) }\end{array}$ & $\begin{array}{l}\text { Two primary } \\
\text { outcomes: } \\
\text { receiving any } \\
\text { CRCS and } \\
\text { being current } \\
\text { for CRCS in } \\
\text { years } 1 \text { and } 2\end{array}$ & $\begin{array}{l}\text { All intervention groups } \\
\text { performed better with } \\
\text { CRCS in both years } 1 \\
\text { and } 2 \text { than control. } \\
\text { Greater intensity of } \\
\text { intervention = direct } \\
\text { correlation with } \\
\text { adherence } \\
\text { UC }=26.3 \% \text { [95\% CI, } \\
23.4 \% \text { to } 29.2 \%] ; \\
\text { UC/AT }=50.8 \% \text { [CI, } \\
47.3 \% \text { to } 54.4 \%] ; \\
\text { UC/AT/AC }=57.5 \% \text { [CI, } \\
54.5 \% \text { to } 60.6 \%] ; \\
\text { UC/RN=64.7\% [CI, } \\
62.5 \% \text { to } 67.0 \%] \\
\text { Secondary outcome: Year } \\
2-\text { The UC/AT/AC and } \\
\text { UC/RN groups had } \\
\text { higher adherence rate } \\
\text { than UC but the UC/AT } \\
\text { did not. } \\
\text { UC = 26.0\% [CI, } 22.8 \% \\
\text { to } 29.2 \% \text { ]; } \\
\text { UC/AT = } 20.7 \% \text { [CI, } \\
17.4 \% \text { to } 24.0 \%] ; \\
\text { UC/AT/AC = 23.0\% [CI, } \\
19.8 \% \text { to } 26.2 \%] ; \\
\text { UC/RN=25.6\% [CI, } \\
23.2 \% \text { to } 28.0 \%]\end{array}$ \\
\hline $\begin{array}{l}\text { Green, B. B., Anderson, } \\
\text { M. L., Cook, A. J., }\end{array}$ & RCT & $\begin{array}{l}\text { Adults patients, aged } \\
50 \text { to } 73 \text { of primary }\end{array}$ & $\begin{array}{l}\text { Study to determine impact of continued } \\
\text { interventions on CRCS up to } 5 \text { years }\end{array}$ & $\begin{array}{l}\text { Not stated. The } \\
\text { approach of the }\end{array}$ & $\begin{array}{l}\text { Compliance } \\
\text { with CRCS }\end{array}$ & $\begin{array}{l}\text { Intervention patients }= \\
31 \% \text { higher compliance }\end{array}$ \\
\hline
\end{tabular}




\begin{tabular}{|c|c|c|c|c|c|c|}
\hline Citation & $\begin{array}{l}\text { Design } \\
\text { Level } \\
\text { Quality } \\
\text { Grade }\end{array}$ & $\begin{array}{c}\text { Sample } \\
\text { Sample size }\end{array}$ & $\begin{array}{l}\text { Intervention } \\
\text { Comparison }\end{array}$ & $\begin{array}{l}\text { Theoretical } \\
\text { Foundation }\end{array}$ & $\begin{array}{l}\text { Outcome } \\
\text { Definition }\end{array}$ & $\begin{array}{c}\text { Usefulness } \\
\text { Results } \\
\text { Key Findings }\end{array}$ \\
\hline \begin{tabular}{|l|} 
Chubak, J., Fuller, S., \\
Meenan, R. T., \& \\
Vernon, S. W. (2017). A \\
centralized mailed \\
program with stepped \\
increases of support \\
increases time in \\
compliance with \\
colorectal cancer \\
screening guidelines \\
over 5 years: A \\
randomized trial. \\
Cancer, 123(22), 4472-- \\
4480. \\
https://doi.org/10.1002/c \\
ncr.30908
\end{tabular} & $\begin{array}{l}\text { Level I } \\
\text { Grade A }\end{array}$ & $\begin{array}{l}\text { care clinics in } \\
\text { Washington state who } \\
\text { participated in an } \\
\text { earlier study (Green et } \\
\text { al., 2013). } \\
\text { Original study arms 2, } \\
3,4 \text { eligible patients re- } \\
\text { randomized } \\
\text { No intervention } \\
(\mathrm{n}=1106) \\
\text { Automated mail } \\
(\mathrm{n}=1102)\end{array}$ & $\begin{array}{l}\text { Intervention: Auto-generated CRCS due } \\
\text { reminder letters; informational pamphlet } \\
\text { about different screening options. Patients } \\
\text { could request alternate screening method } \\
\text { or notified that FOBT kits were coming. } \\
\text { Patients were mailed FOBT kits with } \\
\text { simple instructions and postage-paid } \\
\text { envelope if no alternatives selected } \\
\text { Comparison: usual care - Mailed annual } \\
\text { birthday reminders about preventive health } \\
\text { screening and tests due (including CRCS); } \\
\text { verbal screening reminder at time of visit }\end{array}$ & $\begin{array}{l}\text { interventions point } \\
\text { to a theoretical } \\
\text { foundation in the } \\
\text { socioecological } \\
\text { model (Gili et al., } \\
2006) \text {. }\end{array}$ & $\begin{array}{l}\text { guidelines } \\
\text { over } 5 \text { years }\end{array}$ & $\begin{array}{l}\text { over } 5 \text { years (incidence } \\
\text { rate ratio, } 1.31 ; 95 \% \\
\text { confidence interval, } 1.25- \\
1.37 ; 47.5 \% \text { vs } 62.1 \% \text { ). } \\
\text { Long term study showing } \\
\text { mailed interventions } \\
\text { remain effective over } \\
\text { long term compared to } \\
\text { usual care. }\end{array}$ \\
\hline \begin{tabular}{|l|} 
Hendren, S., Winters, P., \\
Humiston, S., Idris, A., \\
Li, S. X. L., Ford, P., \\
Specht, R., Marcus, S., \\
Mendoza, M., \& \\
Fiscella, K. (2014). \\
Randomized, controlled \\
trial of a multimodal \\
intervention to improve \\
cancer screening rates in \\
a safety-net primary care \\
practice. Journal of \\
General Internal \\
Medicine, 29(1), 41-49. \\
https://doi.org/10.1007/s \\
11606-013-2506-1
\end{tabular} & $\begin{array}{l}\text { RCT } \\
\text { Level I } \\
\text { Grade A }\end{array}$ & $\begin{array}{l}\text { Adult patients, aged } \\
50-74 \text { years past due } \\
\text { for CRC screen and } \\
\text { women aged } 40-74 \\
\text { years past due for } \\
\text { breast cancer }(\mathrm{BC}) \\
\text { screening receiving } \\
\text { care in a safety net } \\
\text { clinic in urban New } \\
\text { York } \\
\text { Intervention }(\mathrm{n}=185) \\
\text { Control }(\mathrm{n}=181)\end{array}$ & $\begin{array}{l}\text { Study to determine impact of intervention } \\
\text { on increasing cancer screening among } \\
\text { patients in a safety-net primary care } \\
\text { practice } \\
\text { Study period: April to September } 2010 \\
\text { Multi-modal interventions: } \\
\text { Letters = mailed personalized letter } \\
\text { indicated the patient was overdue for } \\
\text { mammogram, CRCS or both. Letter } \\
\text { included education and stressed } \\
\text { importance of screening; information on } \\
\text { free cancer screening; outreach worker } \\
\text { contact information. Letter \#2 was sent } \\
\text { week } 12 \text { for any remaining unscreened. } \\
\text { FIT kits also mailed if due } \\
\text { Phone = Automated telephone reminder } \\
\text { calls on weeks } 2,6,14 \text { and } 25 \text { with similar } \\
\text { information to letters but brief } 25 \text { second } \\
\text { message with a phone number to call to }\end{array}$ & $\begin{array}{l}\text { Not stated. The } \\
\text { multiple } \\
\text { interventions is } \\
\text { consistent with the } \\
\text { theoretical } \\
\text { foundation in the } \\
\text { socioecological } \\
\text { model (Gili et al., } \\
\text { 2006). }\end{array}$ & $\begin{array}{l}\text { Mammo- } \\
\text { gram; CRCS } \\
\text { completion }\end{array}$ & 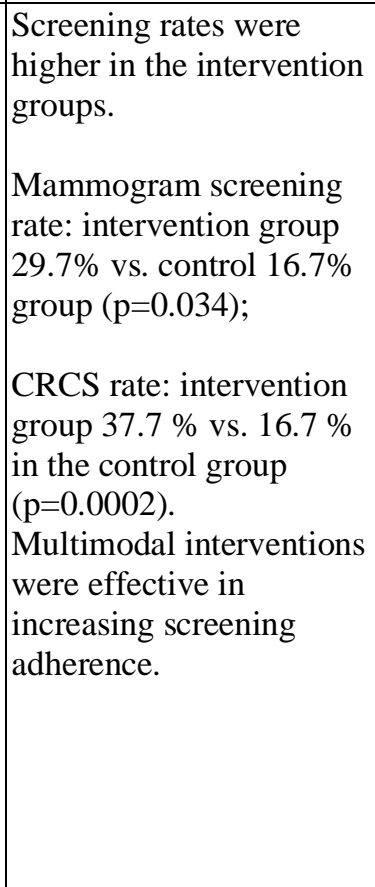 \\
\hline
\end{tabular}




\begin{tabular}{|c|c|c|c|c|c|c|}
\hline Citation & $\begin{array}{l}\text { Design } \\
\text { Level } \\
\text { Quality } \\
\text { Grade }\end{array}$ & $\begin{array}{c}\text { Sample } \\
\text { Sample size }\end{array}$ & $\begin{array}{l}\text { Intervention } \\
\text { Comparison }\end{array}$ & $\begin{array}{l}\text { Theoretical } \\
\text { Foundation }\end{array}$ & $\begin{array}{l}\text { Outcome } \\
\text { Definition }\end{array}$ & $\begin{array}{c}\text { Usefulness } \\
\text { Results } \\
\text { Key Findings }\end{array}$ \\
\hline & & & $\begin{array}{l}\text { arrange for screening. } \\
\text { Point-of-Care written prompt sheets = } \\
\text { Sheet provided to any patients with } \\
\text { screenings due. Prompt sheet = a reminder } \\
\text { for screening for providers and patients. } \\
\text { The back of the sheet provided educational } \\
\text { information about CRCS options. } \\
\text { Comparison: Usual care (details were not } \\
\text { specified in the article) }\end{array}$ & & & \\
\hline \begin{tabular}{|l|} 
Myers, R. E., Bittner- \\
Fagan, H., Daskalakis, \\
C., Sifri, R., Vernon, S. \\
W., Cocroft, J., Dicarlo, \\
M., Katurakes, N., \& \\
Andrel, J. (2013). A \\
randomized controlled \\
trial of a tailored \\
navigation and a \\
standard intervention in \\
colorectal cancer \\
screening. Cancer \\
Epidemiology, \\
Biomarkers \& \\
Prevention: A \\
Publication of the \\
American Association \\
for Cancer Research, \\
Cosponsored by the \\
American Society of \\
Preventive Oncology, \\
22(1), 109-117. \\
https://doi.org/10.1158/1 \\
055-9965.EPI-12-0701
\end{tabular} & $\begin{array}{l}\text { RCT } \\
\text { Level I } \\
\text { Grade A }\end{array}$ & $\begin{array}{l}\text { Adult patients ages 50- } \\
79 \text { receiving care at } \\
\text { primary care clinics in } \\
\text { Delaware } \\
3 \text { arms: } \\
\text { Arm } 1=\text { Tailored } \\
\text { Navigation } \\
\text { Intervention (TNI) } \\
\text { Group ( }=312) \\
\text { Arm } 3=\text { Standard } \\
\text { Intervention (SI) Group } \\
(\mathrm{n}=316 \text { ) } \\
\text { Arm } 4=\text { usual care = } \\
\text { Control Group ( }=317 \text { ) }\end{array}$ & $\begin{array}{l}\text { Study to determine impact of interventions } \\
\text { on CRCS and screening decisions } \\
\text { Study conducted between } 2007 \text { and } 2011 \\
\text { Interventions: } \\
\text { All patients received baseline survey } \\
\text { Preventive Health Model Screening } \\
\text { Decision Stage (SDS) to identify potential } \\
\text { barriers to colorectal cancer screening. } \\
\text { SDS tool has been studied as valid and } \\
\text { reliable in previous studies (Myers et al., } \\
\text { 1994; Vernon et al., 1997). } \\
\text { TNI Group intervention = mailings with } \\
\text { colonoscopy instructions and/or stool } \\
\text { blood tests according to reported test } \\
\text { preference, and received a navigation call } \\
\text { from a nurse navigator } \\
\text { The SI Group intervention = mailings with } \\
\text { an informational booklet on CRCS, a } \\
\text { personalized letter with phone numbers to } \\
\text { a nurse, scheduling colonoscopy or SBT } \\
\text { kit request. Reminder letter mailed at } 30 \\
\text { days post-randomization. }\end{array}$ & $\begin{array}{l}\text { The authors } \\
\text { identified the PHM } \\
\text { model as the } \\
\text { theoretical } \\
\text { foundation for the } \\
\text { study. }\end{array}$ & $\begin{array}{l}\text { Primary } \\
\text { outcome = } \\
\text { CRCS } \\
\text { completion } \\
\text { Secondary } \\
\text { outcome = } \\
\text { change in } \\
\text { overall SDS } \\
\text { between the } \\
\text { baseline and } \\
\text { the endpoint } \\
\text { surveys }\end{array}$ & $\begin{array}{l}\text { Results: } \\
\text { CRCS completion: } \\
\text { TNI Group: } 38 \% \text { (P=- } \\
\text { 0.001) } \\
\text { SI Group: } 33 \%(\mathrm{P}=0.001) \\
\text { Control Group: } 12 \% \\
\text { but no significant } \\
\text { difference between the } \\
\text { TNI and SI groups } \\
\text { Secondary outcome: } \\
\text { SDS change from the } \\
\text { lower decision stages to } \\
\text { the decided-to-do or } \\
\text { screened stages } \\
\text { (TNI Group: } 91 \%, \text { SI } \\
\text { Group: } 87 \%, \text { Control } \\
\text { Group: } 81 \% \text { ) } \\
\text { Conclusions: Both } \\
\text { interventions had } \\
\text { significant, positive } \\
\text { effects on outcomes } \\
\text { compared with usual }\end{array}$ \\
\hline
\end{tabular}




\begin{tabular}{|c|c|c|c|c|c|c|}
\hline Citation & $\begin{array}{c}\text { Design } \\
\text { Level } \\
\text { Quality } \\
\text { Grade }\end{array}$ & $\begin{array}{c}\text { Sample } \\
\text { Sample size }\end{array}$ & $\begin{array}{l}\text { Intervention } \\
\text { Comparison }\end{array}$ & $\begin{array}{l}\text { Theoretical } \\
\text { Foundation }\end{array}$ & $\begin{array}{l}\text { Outcome } \\
\text { Definition }\end{array}$ & $\begin{array}{l}\text { Usefulness } \\
\text { Results } \\
\text { Key Findings }\end{array}$ \\
\hline & & & $\begin{array}{l}\text { Comparison: } \\
\text { Control group = usual care (not described } \\
\text { in article). }\end{array}$ & & & \\
\hline \begin{tabular}{|l|} 
Sequist, T. D., \\
Zaslavsky, A. M., \\
Marshall, R., Fletcher, \\
R. H., \& Ayanian, J. Z. \\
(2009). Patient and \\
physician reminders to \\
promote colorectal \\
cancer screening: A \\
randomized controlled \\
trial. Archives of \\
Internal Medicine, \\
169(4), 364-371. \\
https://doi.org/10.1001/a \\
rchinternmed.2008.564
\end{tabular} & $\begin{array}{l}\text { RCT } \\
\text { Level I } \\
\text { Grade A }\end{array}$ & $\begin{array}{l}\text { Adult patients, aged } 50 \\
\text { to } 80 \text { years of } \\
\text { ambulatory health } \\
\text { centers in } \\
\text { Massachusetts. } \\
4 \text { arms: } \\
\text { Arm 1: Patient } \\
\text { intervention group } \\
(\mathrm{n}=10,930) \\
\text { Arm 2: Patient control } \\
\text { group (n=10,930) } \\
\text { Arm 3: MD } \\
\text { intervention group } \\
(\mathrm{n}=10,912) \\
\text { Arm } 4: \text { MD control } \\
\text { group ( } \mathrm{n}=10,948)\end{array}$ & $\begin{array}{l}\text { Study aim: determine impact of } \\
\text { personalized mailings to patients and } \\
\text { electronic reminders to primary care } \\
\text { physicians on colorectal cancer screening } \\
\text { Interventions: } \\
\text { Study done between April } 2006 \text { and July } \\
2007 \\
\text { Arm } 1 \text { - Patient intervention -mailing with } \\
\text { a cover letter from the chief medical } \\
\text { officer with details about their last } \\
\text { screening dates; educational pamphlet } \\
\text { detailing screening options; an FOBT kit } \\
\text { with } 3 \text { stool cards, stamped return } \\
\text { envelope; dedicated phone number to } \\
\text { schedule FS or colonoscopy } \\
\text { Arm } 2 \text { - Patient control - usual care } \\
\text { (details not included in the article) } \\
\text { Arm } 3 \text {-MD intervention - reminders via } \\
\text { the electronic health record as a pop-up } \\
\text { alert and also available for reviewing any } \\
\text { time. One-click ordering option with } \\
\text { choices of screening options. } \\
\text { Arm } 4 \text { - MD control - Comparison: } \\
\text { Control group was educated on the alerts } \\
\text { but did not have the alerts turned on. }\end{array}$ & $\begin{array}{l}\text { Not stated by the } \\
\text { authors. The } \\
\text { approach of the } \\
\text { study is consistent } \\
\text { with the Precaution } \\
\text { Adoption Process. } \\
\text { The aim of the study } \\
\text { was to explore if } \\
\text { providing education } \\
\text { and information to } \\
\text { patients impact the } \\
\text { engagement and } \\
\text { decision of health } \\
\text { behaviors } \\
\text { (Weinstein \& } \\
\text { Sandman, 1992). }\end{array}$ & $\begin{array}{l}\text { Completion } \\
\text { of } 1 \text { of } \\
\text { FOBT, FS, } \\
\text { or colon- } \\
\text { oscopy. } \\
\text { Secondary } \\
\text { study } \\
\text { outcome = } \\
\text { detection of } \\
\text { adenomas }\end{array}$ & $\begin{array}{l}\text { Patient intervention arm } \\
=\text { significantly more } \\
\text { likely to complete CRCS } \\
\text { than control group } \\
(44.0 \% \text { vs } 38.1 \% ; P .001) \\
\text { MD intervention arm: no } \\
\text { difference in CRCS } \\
(41.9 \% \text { vs } 40.2 \% ; \mathrm{P}=.47) . \\
\text { No difference in } \\
\text { detection of adenomas } \\
\text { but a trend towards } \\
\text { significance in both } \\
\text { intervention groups. }\end{array}$ \\
\hline \begin{tabular}{|l} 
Tu, S.-P., Chun, A., \\
Yasui, Y., Kuniyuki, A., \\
Yip, M.-P., Taylor, V., \\
\& Bastani, R. (2014).
\end{tabular} & \begin{tabular}{l|}
$\begin{array}{l}\text { Quasi- } \\
\text { experimental }\end{array}$ \\
Level II
\end{tabular} & $\begin{array}{l}\text { Vietnamese adult } \\
\text { patients; aged } 50 \text { to } 75 \\
\text { years of community }\end{array}$ & $\begin{array}{l}\text { Study to determine the impact of culturally } \\
\text { tailored interventions on colorectal cancer } \\
\text { screening }\end{array}$ & $\begin{array}{l}\text { Authors state the } \\
\text { study framework = } \\
\text { Diffusion of } \\
\text { Innovations Theory }\end{array}$ & $\begin{array}{l}\text { Time limited } \\
\text { study. } \\
\text { Adherence to } \\
\text { CRCS }\end{array}$ & $\begin{array}{l}\text { Marginally significant } \\
\text { increase in CRCS in } \\
\text { intervention clinic (the }\end{array}$ \\
\hline
\end{tabular}




\begin{tabular}{|c|c|c|c|c|c|c|}
\hline Citation & $\begin{array}{c}\text { Design } \\
\text { Level } \\
\text { Quality } \\
\text { Grade }\end{array}$ & $\begin{array}{c}\text { Sample } \\
\text { Sample size }\end{array}$ & $\begin{array}{l}\text { Intervention } \\
\text { Comparison }\end{array}$ & $\begin{array}{l}\text { Theoretical } \\
\text { Foundation }\end{array}$ & $\begin{array}{l}\text { Outcome } \\
\text { Definition }\end{array}$ & $\begin{array}{c}\text { Usefulness } \\
\text { Results } \\
\text { Key Findings }\end{array}$ \\
\hline $\begin{array}{l}\text { Adaptation of an } \\
\text { evidence-based } \\
\text { intervention to promote } \\
\text { colorectal cancer } \\
\text { screening: A quasi- } \\
\text { experimental study. } \\
\text { Implementation Science: } \\
\text { IS, 9, 85. } \\
\text { https://doi.org/10.1186/1 } \\
748-5908-9-85\end{array}$ & $\begin{array}{l}\text { Pre-Post } \\
\text { Design } \\
\text { Cross- } \\
\text { sectional } \\
\text { Non- } \\
\text { equivalent } \\
\text { control } \\
\text { Grade A }\end{array}$ & $\begin{array}{l}\text { health centers in } \\
\text { Washington } \\
\text { Baseline: } \\
\text { Control }(n=412) \\
\text { Intervention }(n=604) \\
\text { Post-Intervention: } \\
\text { Control }(n=514) \\
\text { Intervention }(n=746)\end{array}$ & $\begin{array}{l}\text { Study period March, } 2009 \text { to February, } \\
2011 \\
\text { Comparison of } 2 \text { clinics: control and } \\
\text { intervention clinic } \\
\text { Intervention: Vietnamese small media } \\
\text { (DVD and pamphlet); medical assistants } \\
\text { gave small media and education to patients } \\
\text { Usual care: CRCS = FOBT ordered by } \\
\text { primary care providers then patient given } \\
\text { FOBT card by medical assistant to patients } \\
\text { with verbal instructions }\end{array}$ & & & $\begin{array}{l}\text { ratio of the two ORs }= \\
1.42 ; 95 \% \text { CI } 0.95,2.15)\end{array}$ \\
\hline $\begin{array}{l}\text { Wong, M. C., Ching, J. } \\
\text { Y., Huang, J., Wong, J. } \\
\text { C., Lam, T. Y., Chan, V. } \\
\text { C., Ng, S. K., Hui, Z., } \\
\text { Luk, A. K., Wu, J. C., \& } \\
\text { Chan, F. K. (2018). } \\
\text { Effectiveness of } \\
\text { reminder strategies on } \\
\text { cancer screening } \\
\text { adherence: A } \\
\text { randomised controlled } \\
\text { trial. The British Journal } \\
\text { of General Practice: The } \\
\text { Journal of the Royal } \\
\text { College of General } \\
\text { Practitioners, 68(674), } \\
\text { e604-e611. } \\
\text { https://doi.org/10.3399/b } \\
\text { jgp18X698369et al., } \\
\text { 2018 }\end{array}$ & $\begin{array}{l}\text { RCT } \\
\text { Level I } \\
\text { Grade A }\end{array}$ & $\begin{array}{l}\text { Adults patients, aged } \\
40 \text { to } 70 \text { of primary } \\
\text { care clinics in Hong } \\
\text { Kong } \\
3 \text { arms: } \\
\text { Interventions: } \\
\text { Arm 1: Text ( }=212) \\
\text { Arm 2: Phone messages } \\
(207) \\
\text { Arm 3: Control - no } \\
\text { communication } \\
(\mathrm{n}=210)\end{array}$ & $\begin{array}{l}\text { Study to determine the impact of } \\
\text { interventions on FIT screening compliance } \\
\text { Interventions: } \\
\text { Text group: One-way text messages to } \\
\text { patient's cell phone with reminder about } \\
\text { the importance of regular CRCS, } \\
\text { and the time and place for of FIT kit pick } \\
\text { up } \\
\text { Phone group: Call from healthcare } \\
\text { professionals with same message as text } \\
\text { group except that the screening participants } \\
\text { were able to talk with healthcare } \\
\text { professionals } \\
\text { Comparison: Control group: } \\
\text { No communication }\end{array}$ & $\begin{array}{l}\text { The authors } \\
\text { identified the } \\
\text { PRECEDE- } \\
\text { PROCEED } \\
\text { Model = theoretical } \\
\text { foundation }\end{array}$ & $\begin{array}{l}\text { FIT test } \\
\text { submitted }\end{array}$ & $\begin{array}{l}\text { FIT test returned on } \\
\text { anniversary date: } \\
86.5 \% \text { Control } \\
90.4 \% \text { Text } \\
95.1 \% \text { Phone } \\
(\mathrm{P}=0.010) \\
\text { At } 6 \text { months return rate: } \\
94.1 \%, \text { Phone } \\
90.0 \%, \text { Text } \\
86.0 \% \text { Control }(\mathrm{P}= \\
0.022) \\
\text { Compared with the } \\
\text { control telephone group } \\
\text { were significantly more } \\
\text { likely return FIT test. } \\
\text { (AOR = 2.73, 95\% CI = } \\
1.35 \text { to 5.53, P = 0.005) } \\
\text { Text only intervention } \\
\text { did not have a significant } \\
\text { difference compared to } \\
\text { the control group }\end{array}$ \\
\hline
\end{tabular}




\begin{tabular}{|c|c|c|c|c|c|c|}
\hline Citation & $\begin{array}{l}\text { Design } \\
\text { Level } \\
\text { Quality } \\
\text { Grade }\end{array}$ & $\begin{array}{c}\text { Sample } \\
\text { Sample size }\end{array}$ & $\begin{array}{l}\text { Intervention } \\
\text { Comparison }\end{array}$ & $\begin{array}{l}\text { Theoretical } \\
\text { Foundation }\end{array}$ & $\begin{array}{c}\text { Outcome } \\
\text { Definition }\end{array}$ & $\begin{array}{c}\text { Usefulness } \\
\text { Results } \\
\text { Key Findings }\end{array}$ \\
\hline & & & & & & $\begin{array}{l}\text { The interaction with a } \\
\text { trained health } \\
\text { professional had a higher } \\
\text { impact on the adherence } \\
\text { rate with CRCS } \\
\text { Generalizability to the } \\
\text { US may be limited }\end{array}$ \\
\hline $\begin{array}{l}\text { Yu, C., Skootsky, S., } \\
\text { Grossman, M., Garner, } \\
\text { O. B., Betlachin, A., } \\
\text { Esrailian, E., Hommes, } \\
\text { D. W., \& May, F. P. } \\
\text { (2018). A multi-level fit- } \\
\text { based quality } \\
\text { improvement initiative } \\
\text { to improve colorectal } \\
\text { cancer screening in a } \\
\text { managed care } \\
\text { population. Clinical and } \\
\text { Translational } \\
\text { Gastroenterology, 9(8), } \\
\text { 177. } \\
\text { https://doi.org/10.1038/s } \\
\text { 41424-018-0046-z }\end{array}$ & $\begin{array}{l}\text { Quasi- } \\
\text { experimental } \\
\text { Level II } \\
\text { Pre-Post } \\
\text { Grade A }\end{array}$ & $\begin{array}{l}\text { Adult patients, aged } 51 \\
\text { to } 75 \text { of a large } \\
\text { university-affiliated } \\
\text { health system in } \\
\text { California } \\
\text { Sample }(n=5093)\end{array}$ & \begin{tabular}{|l} 
Study to determine impact of a multi- \\
modal intervention on CRCS \\
Study dates: June 2015 and October 2014 \\
Interventions: \\
Patient-level = Letter with education about \\
screening options and pre-colonoscopy \\
telephone counseling plus a FIT kit. \\
Reminder letter sent after 4 months if not \\
returned. \\
Physician level = Provided screening test \\
results and work-flow for abnormal results. \\
System-level = establishment of a patient \\
navigator, expedited work-up for abnormal \\
results, and stream-lined colonoscopy \\
scheduling.
\end{tabular} & $\begin{array}{l}\text { Not stated. Study } \\
\text { approach is } \\
\text { consistent with the } \\
\text { socioecological } \\
\text { model (Gili et al., } \\
\text { 2006) }\end{array}$ & $\begin{array}{l}\text { CRCS } \\
\text { adherence }\end{array}$ & $\begin{array}{l}\text { CRCS rate increased } \\
\text { from } 65.1 \% \text { prior to } \\
\text { intervention and } 76.6 \% \\
\text { after the intervention }\end{array}$ \\
\hline
\end{tabular}

Note: Levels and quality of evidence ranked using Johns Hopkins Nursing Evidence-Based Nursing Evidence Level and Quality Guide (Dang \& Dearholt, 2017).

Legend: Colorectal Cancer (CRC); Colorectal Cancer Screening (CRCS); Confidence Interval (CI); Double Contrast Barium Enema (DCBE); Fecal Immunochemical Test (FIT); Fecal Occult Blood Test (FOBT); Flexible Sigmoidoscopy (FS); Odds Ratio (OR); Randomized Controlled Trial (RCT); Stool Blood Test (SBT) 


\section{Appendix B}

\section{Summary of Systematic Reviews (SR)}

\begin{tabular}{|c|c|c|c|c|c|c|c|}
\hline Citation & $\begin{array}{l}\text { Quality } \\
\text { Grade }\end{array}$ & Question & $\begin{array}{l}\text { Search } \\
\text { Strategy }\end{array}$ & $\begin{array}{c}\text { Inclusion/ } \\
\text { Exclusion Criteria }\end{array}$ & $\begin{array}{c}\text { Data Extraction } \\
\text { and Analysis }\end{array}$ & Key Findings & $\begin{array}{c}\text { Usefulness/ } \\
\text { Recommendation/ } \\
\text { Implications }\end{array}$ \\
\hline $\begin{array}{l}\text { Dougherty, M. K., } \\
\text { Brenner, A. T., } \\
\text { Crockett, S. D., } \\
\text { Gupta, S., } \\
\text { Wheeler, S. B., } \\
\text { Coker- } \\
\text { Schwimmer, M., } \\
\text { Cubillos, L., Malo, } \\
\text { T., \& Reuland, D. } \\
\text { S. (2018). } \\
\text { Evaluation of } \\
\text { interventions } \\
\text { intended to } \\
\text { increase colorectal } \\
\text { cancer screening } \\
\text { rates in the United } \\
\text { States: A } \\
\text { systematic review } \\
\text { and meta-analysis. } \\
\text { JAMA Internal } \\
\text { Medicine, 178(12), } \\
1645-1658 . \\
\text { https://doi.org/10.1 } \\
\text { 001/jamainternmed } \\
.2018 .4637\end{array}$ & $\begin{array}{c}\text { Level I } \\
\text { Grade A }\end{array}$ & $\begin{array}{l}\text { What interventions } \\
\text { increase CRCS } \\
\text { completion? }\end{array}$ & $\begin{array}{l}\text { Electronic } \\
\text { databases: } \\
\text { PubMed, } \\
\text { CINAHL, } \\
\text { Cochrane } \\
\text { Library, } \\
\text { ClinicalTrials. } \\
\text { gov } \\
\text { Key words: } \\
\text { colorectal } \\
\text { cancer and } \\
\text { screening. }\end{array}$ & $\begin{array}{l}\text { Inclusion: English, } \\
\text { RCTs, published } \\
\text { from } 1 / 1 / 96 \text { to } \\
8 / 31 / 17 \\
\text { Original research } \\
\text { only, full-length } \\
\text { publications. } \\
\text { Exclusion: not } \\
\text { presenting original } \\
\text { data (i.e. cost } \\
\text { effectiveness } \\
\text { analyses of trials } \\
\text { already/separately } \\
\text { published) }\end{array}$ & $\begin{array}{l}\text { Data extracted } \\
\text { and appraised by } \\
>2 \text { investigators } \\
\text { independently } \\
\text { Random-effects } \\
\text { meta-analysis } \\
\text { used to obtain } \\
\text { either a pooled } \\
\text { risk ratio or risk } \\
\text { difference for } \\
\text { screening } \\
\text { completion for } \\
\text { each type of } \\
\text { intervention. }\end{array}$ & $\begin{array}{l}73 \text { RCTs } \\
\text { FOBT outreach and patient } \\
\text { navigation, especially multi- } \\
\text { component interventions } \\
\text { showed increased CRCS } \\
\text { rates in US trials }\end{array}$ & $\begin{array}{l}\text { Useful information to } \\
\text { support use of multi- } \\
\text { component strategy for } \\
\text { CRCS }\end{array}$ \\
\hline
\end{tabular}




\begin{tabular}{|c|c|c|c|c|c|c|c|}
\hline Citation & $\begin{array}{l}\text { Quality } \\
\text { Grade }\end{array}$ & Question & $\begin{array}{l}\text { Search } \\
\text { Strategy }\end{array}$ & $\begin{array}{c}\text { Inclusion/ } \\
\text { Exclusion Criteria }\end{array}$ & $\begin{array}{c}\text { Data Extraction } \\
\text { and Analysis }\end{array}$ & Key Findings & $\begin{array}{c}\text { Usefulness/ } \\
\text { Recommendation/ } \\
\text { Implications }\end{array}$ \\
\hline $\begin{array}{l}\text { U.S. Department } \\
\text { of Health and } \\
\text { Human Services. } \\
\text { (2020). Cancer } \\
\text { screening: } \\
\text { Multicomponent } \\
\text { interventions- } \\
\text { Colorectal cancer. } \\
\text { https://www.theco } \\
\text { mmunityguide.org/ } \\
\text { findings/cancer- } \\
\text { screening- } \\
\text { multicomponent- } \\
\text { interventions- } \\
\text { colorectal-cancer }\end{array}$ & $\begin{array}{l}\text { Level II } \\
\text { Grade A }\end{array}$ & $\begin{array}{l}\text { Compared with no } \\
\text { intervention which } \\
\text { multi-component } \\
\text { interventions } \\
\text { increased CRCS? }\end{array}$ & $\begin{array}{l}\text { Electronic } \\
\text { databases: } \\
\text { PubMED, } \\
\text { Medline, } \\
\text { PsycINFO, } \\
\text { Embase, } \\
\text { CINAHL, } \\
\text { Cochrane, } \\
\text { Chronic } \\
\text { Disease } \\
\text { Prevention, } \\
\text { Web of } \\
\text { Science }\end{array}$ & $\begin{array}{l}\text { Inclusion: English- } \\
\text { language; } \\
\text { multicomponent } \\
\text { interventions on } \\
\text { breast, cervical, or } \\
\text { colorectal cancer } \\
\text { screening in high- } \\
\text { income countries. } \\
\text { Search period: } \\
\text { January } 2004 \text { - } \\
\text { November } 2013 \\
\text { Exclusion: not } \\
\text { specified }\end{array}$ & $\begin{array}{l}\text { Screened } \\
\text { independently by } \\
\text { two abstractors } \\
\text { Data evaluation = } \\
\text { stratified analyses }\end{array}$ & $\begin{array}{l}\text { Number of cancer screening } \\
\text { studies included: } \\
\text { Total } 88 \text {-: breast (33), } \\
\text { cervical (20), colorectal (56) } \\
\text { RCTs 30, quasi-experimental } \\
26 \\
\text { Multi-component } \\
\text { interventions increased } \\
\text { colorectal cancer screening }\end{array}$ & $\begin{array}{l}\text { Recommendation: } \\
\text { Strong evidence to } \\
\text { support multi- } \\
\text { component } \\
\text { interventions to } \\
\text { increase CRCS. } \\
\text { The interventions were } \\
\text { cost-effective. } \\
\text { Very useful systematic } \\
\text { review which was } \\
\text { developed into a } \\
\text { practice guideline }\end{array}$ \\
\hline $\begin{array}{l}\text { Young, B.-R., } \\
\text { Gwede, C. K., } \\
\text { Thomas, B., } \\
\text { Vázquez-Otero, C., } \\
\text { Ewing, A., Best, } \\
\text { A. L., Aguado Loi, } \\
\text { C. X., Martinez- } \\
\text { Tyson, D., } \\
\text { Schneider, T., } \\
\text { Meade, C. D., } \\
\text { Baldwin, J. A., \& } \\
\text { Bryant, C. (2019). } \\
\text { A systematic } \\
\text { review of U.S.- } \\
\text { based colorectal } \\
\text { cancer screening } \\
\text { uptake intervention } \\
\text { systematic } \\
\text { reviews: Available } \\
\text { evidence and } \\
\text { lessons learned for } \\
\text { research and } \\
\text { practice. Frontiers } \\
\text { in Public Health, } 7 . \\
\text { https://doi.org/10.3 }\end{array}$ & $\begin{array}{l}\text { Level II } \\
\text { Grade A }\end{array}$ & $\begin{array}{l}\text { What are the EBP } \\
\text { interventions for } \\
\text { colorectal cancer } \\
\text { screening (CRCS), } \\
\text { their effect size, and } \\
\text { their characteristics? }\end{array}$ & \begin{tabular}{|l|} 
Electronic \\
databases \\
CINAHL, \\
rTIPS, \\
PubMed, \\
Cochrane \\
Library, \\
PsycINFO, \\
EBSCO, \\
Review of \\
reference \\
section of each \\
systematic \\
review.
\end{tabular} & $\begin{array}{l}\text { Inclusion: Eligible } \\
\text { systematic reviews: } \\
\text { published in } \\
\text { English, only } \\
\text { studies conducted in } \\
\text { U.S. and/or its } \\
\text { territories. } \\
\text { Study types: RCTs, } \\
\text { quasi-experimental, } \\
\text { or single arm } \\
\text { intervention design } \\
\text { Outcome: CRCS } \\
\text { uptake per U.S. } \\
\text { Preventive Services } \\
\text { Task Force } \\
\text { guideline } \\
\text { Study date range } \\
\text { 1986 to 2013 } \\
\text { Exclusion: } \\
\text { Non-English; } \\
\text { articles that solely }\end{array}$ & $\begin{array}{l}\text { One author } \\
\text { abstracted the } \\
\text { data, another } \\
\text { independently } \\
\text { reviewed all data. } \\
\text { Arbitrator for } \\
\text { disagreements } \\
\text { Effect size to } \\
\text { measure } \\
\text { magnitude of } \\
\text { difference }\end{array}$ & $\begin{array}{l}16 \text { systematic reviews } \\
\text { totaling } 116 \text { unique } \\
\text { individual studies contained } \\
\text { within the systematic reviews } \\
\text { Inconsistent evidence to } \\
\text { support: } \\
\text { - provider assessment and } \\
\text { feedback for any } \\
\text { screening other than } \\
\text { FOBT } \\
\text { - client reminders for any } \\
\text { screening other than } \\
\text { FOBT } \\
\text { - small media on increasing } \\
\text { sigmoidoscopy, } \\
\text { colonoscopy, or DCBE } \\
\text { - client incentives } \\
\text { - reducing client out of } \\
\text { pocket costs } \\
\text { - client group education }\end{array}$ & $\begin{array}{l}\text { Helpful information } \\
\text { for focusing } \\
\text { interventions } \\
\text { on components that } \\
\text { had the largest effect } \\
\text { size }\end{array}$ \\
\hline
\end{tabular}




\begin{tabular}{|c|c|c|c|c|c|c|c|}
\hline Citation & $\begin{array}{l}\text { Quality } \\
\text { Grade }\end{array}$ & Question & $\begin{array}{c}\text { Search } \\
\text { Strategy }\end{array}$ & \begin{tabular}{|c|} 
Inclusion/ \\
Exclusion Criteria
\end{tabular} & $\begin{array}{c}\text { Data Extraction } \\
\text { and Analysis }\end{array}$ & Key Findings & $\begin{array}{c}\text { Usefulness/ } \\
\text { Recommendation/ } \\
\text { Implications }\end{array}$ \\
\hline $\begin{array}{l}389 / \text { fpubh.2019.00 } \\
145\end{array}$ & & & & $\begin{array}{l}\text { focused on } \\
\text { improving } \\
\text { intentions to be } \\
\text { screened }\end{array}$ & & $\begin{array}{l}\text { Most effective: (a) allowing } \\
\text { clients to select a screening } \\
\text { modality; option from a } \\
\text { colonoscopy, FOBT, or } \\
\text { sigmoidoscopy' (b) patient } \\
\text { navigators or a patient- } \\
\text { referral structures or } \\
\text { provider-level intervention } \\
\text { through provider assessment } \\
\text { and feedback }\end{array}$ & \\
\hline
\end{tabular}

Legend: Colorectal Cancer Screening (CRCS); Double Contrast Barium Enema (DCBE); Fecal Occult Blood Test (FOBT) 


\section{Appendix C}

\section{Study Themes}

\begin{tabular}{|c|c|c|c|c|c|c|c|c|c|c|c|c|c|c|c|c|c|c|c|c|}
\hline Theme & Subtheme & 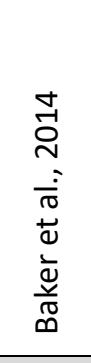 & 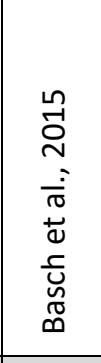 & 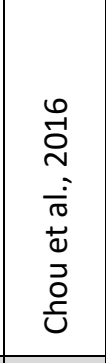 & 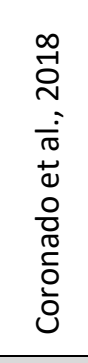 & 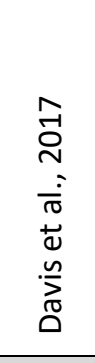 & 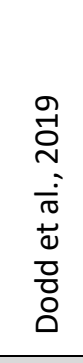 & 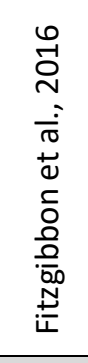 & 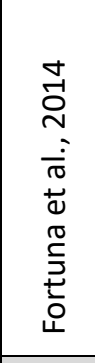 & 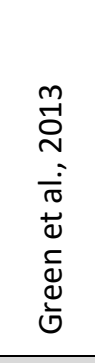 & 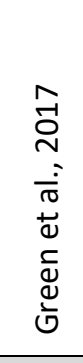 & 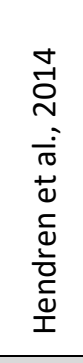 & 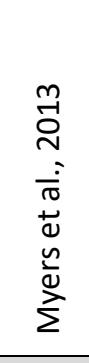 & 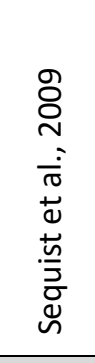 & 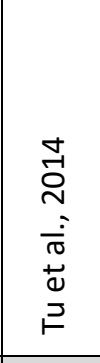 & 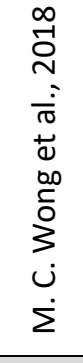 & 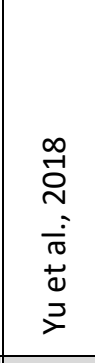 & 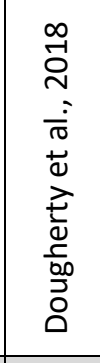 & 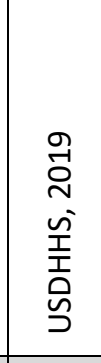 & 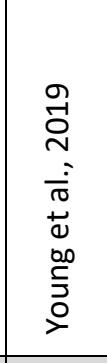 \\
\hline & Study Type & R-I-A & Q-II-B & Q-II-A & R-I-A & R-I-A & $\mathrm{R}-\mathrm{I}-\mathrm{C}$ & R-I-A & Q-II-A & R-I-A & R-I-A & R-I-A & R-I-A & R-I-A & Q-II-A & R-I-A & Q-II-A & SR-I-A & SR-II-A & SR-II-A \\
\hline \multirow{4}{*}{$\begin{array}{l}\text { Patient } \\
\text { Outreach }\end{array}$} & Letters & $x$ & & & $x$ & & & & $x$ & $x$ & $x$ & $x$ & $x$ & $x$ & & & $x$ & & $x$ & \\
\hline & $\begin{array}{l}\text { Auto phone } \\
\text { message/text }\end{array}$ & $x$ & & & & & & & $x$ & & & $x$ & & & & $x$ & & & $x$ & \\
\hline & Navigator & $x$ & $x$ & & & & $x$ & & $x$ & $x$ & & & $x$ & & & $x$ & $x$ & $x$ & $x$ & $x$ \\
\hline & FOBT kit & $x$ & & $x$ & $x$ & & $x$ & & & $x$ & $x$ & $x$ & $x$ & $x$ & & & $x$ & $x$ & $x$ & \\
\hline \multirow{2}{*}{$\begin{array}{l}\text { Patient } \\
\text { Education }\end{array}$} & Written & $x$ & $x$ & & & $x$ & $x$ & $x$ & $x$ & $x$ & $x$ & $x$ & $x$ & & $x$ & & $x$ & $x$ & $x$ & $x$ \\
\hline & Video & & & $x$ & & $x$ & & $x$ & & & & & & & $x$ & & & & $x$ & \\
\hline \multirow{3}{*}{$\begin{array}{l}\text { Clinician } \\
\text { Directed }\end{array}$} & Clinician education & & $x$ & & & & & $x$ & & & & & & & & & & & & \\
\hline & Clinician feedback & & & & & & & $x$ & & & & & & & & & & & $x$ & $x$ \\
\hline & Clinician reminder & & & & & & & & & & & & & $x$ & & & & & $x$ & $x$ \\
\hline
\end{tabular}

Legend: R - Randomized Controlled Trial; Q - Quasi-Experimental; SR - Systematic Review; I - Level I; II - Level II; A = Grade A; B = Grade B; $\mathrm{C}=$ Grade $\mathrm{C}$ 


\section{Appendix D}

\section{SWOT Analysis}

\section{STRENGTHS}

- Strong lean culture within the organization

- Supportive leadership

- Engaged staff

- Strong Systems Redesign (process improvement) department

- Existing VA directive that supports the practice

- Daily Management System huddle board for metric tracking

- Lead NPs available

- Dedicated nurse educator available

- PACT (primary care aligned care team) model (medical home model) with an RN care manager in every PACT team

- Goal set to have Magnet recognition. Currently in preapplication phase

\section{OPPORTUNITIES}

- Dashboard for performance feedback available but not used

- Collaborating with other like facilities who are performing well on this metric

- Facility currently has a quarterly process improvement fair for staff to showcase improvement in outcomes

- Pandemic - COVID-19 may improve patient visits using telehealth

\section{WEAKNESSES}

- Limited flexibility in type of FIT kit used

- Lack of a feedback loop from Gl practitioners to primary care

- Nursing and clerical staff floating in from other areas without having received education

- Fears and perceptions about handling stool sample

- Number of patients seen face to face may vary with pandemic surge

- Potential supply chain issues with FIT kits

\section{THREATS}

- Pandemic - COVID-19 causing instability in patient confidence to venture out

- Multiple projects coinciding that impact primary care

- Potential leadership changes may cause change in support

- Change of guideline to start CRCS screening at age 45 


\section{Appendix E}

\section{Project Schedule}

\begin{tabular}{|c|c|c|c|c|c|c|c|c|c|c|c|c|c|c|c|}
\hline \multirow[t]{2}{*}{ Course/Week } & \multicolumn{7}{|c|}{ NUR7802 } & \multicolumn{8}{|c|}{ NUR7803 } \\
\hline & \begin{tabular}{l|l}
- & 3 \\
$\frac{x}{d}$ & $\frac{k}{d}$ \\
$\stackrel{d}{s}$ & $\stackrel{0}{3}$
\end{tabular} & 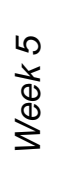 & \begin{tabular}{l}
$N$ \\
$\frac{1}{d}$ \\
\multirow{d}{s}{}
\end{tabular} & $\begin{array}{l}0 \\
\frac{k}{1} \\
\Phi \\
\vdots\end{array}$ & $\begin{array}{l}= \\
\frac{1}{d} \\
0 \\
0\end{array}$ & $\begin{array}{l}\frac{3}{2} \\
\frac{x}{d} \\
₫ \\
3\end{array}$ & $\begin{array}{l}\frac{10}{2} \\
\frac{x}{d} \\
\frac{1}{3}\end{array}$ & 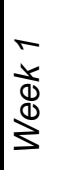 & 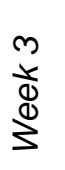 & 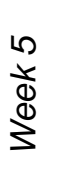 & 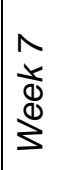 & \begin{tabular}{l}
0 \\
$\frac{1}{8}$ \\
$d$ \\
\multirow{2}{3}{}
\end{tabular} & $\begin{array}{l}2 \\
\frac{x}{2} \\
8 \\
0 \\
3\end{array}$ & $\begin{array}{l}\frac{3}{2} \\
\frac{x}{d} \\
\frac{1}{3}\end{array}$ & $\frac{12}{\frac{1}{2}}$ \\
\hline \multicolumn{16}{|l|}{ Meeting with leadership and lead RN Care Manager to discuss project status } \\
\hline \multicolumn{16}{|l|}{ Obtain EPRC approval from university } \\
\hline \multicolumn{16}{|l|}{ Obtain IRB approval from facility } \\
\hline \multicolumn{16}{|l|}{$\begin{array}{l}\text { Official kick-off meeting with stakeholders (PC staff, nurse scientist, data } \\
\text { analyst, supply chain rep, leadership, PC NSG) }\end{array}$} \\
\hline \multicolumn{16}{|l|}{ Collect baseline data measures (Table 2) } \\
\hline \multicolumn{16}{|l|}{ Lead Care Manager to review new standard work with nursing staff } \\
\hline \multicolumn{16}{|l|}{ Meet with statistician } \\
\hline \multicolumn{16}{|l|}{ Collect data and enter into statistical program } \\
\hline \multicolumn{16}{|l|}{ Analyze data } \\
\hline \multicolumn{16}{|l|}{ Update huddle boards with status of metrics } \\
\hline \multicolumn{16}{|l|}{ Hand-off project to PC lead care manager for sustainment } \\
\hline \multicolumn{16}{|l|}{ Write analysis and conclusion on proposal } \\
\hline Dissemination of findings & & & & & & & & & & & & & & & \\
\hline
\end{tabular}

Legend: PC - primary care; CRCS/S Colorectal Cancer Screening and Surveillance database; PC NSG - primary care nursing shared governance committee 


\section{Appendix F}

\section{Demographic and Colorectal Cancer Screening \& Surveillance Database Use Data Collection}

Date

Dept

To assist in data analysis and interpretation, please provide the following information. All information will be held strictly confidential.

1. Circle the number beside your age range (1) 18-30 (2) 31-40 (3) 41-50 (4) 51-64 (5) $65+$

2. What is your gender? (1) Female (2) Male

3. Circle the number beside your highest level of education: (1) LVN $\quad$ (2) AA/ADN (3) Diploma $\quad$ (4) BSN

$\begin{array}{llll}\text { (5) Master's Degree (6) } \mathrm{DNP} / \mathrm{PhD} & \text { (7) } \mathrm{MD} / \mathrm{DO} & \text { (8) Other }\end{array}$

4. Circle the number of years of experience you have in your profession: (1) 6mo - 1 yr $\quad$ (2) 1 - 3 yrs $\quad$ (3) 3-5yrs $\begin{array}{ll}\text { (4) } 5-10 \mathrm{yrs} & \text { (5) } 10+\mathrm{yrs}\end{array}$

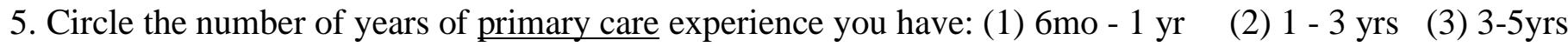
(4) $5-10$ yrs
(5) $10+y r s$

6. How important do you think it is to talk to your patients about colorectal cancer? (check one)

[ ] 0 - not important

[ ] 1 - somewhat important

[ ] 2 - important

[ ] 4-extremely important

7. What is your level of comfort with discussing colorectal cancer with your patients? (check one)

[ ] 0 - not comfortable at all

[ ] 1 - somewhat comfortable

[ ] 2 - comfortable

[ ] 4 - extremely comfortable

8. How many days in the past week have you used the Colorectal Cancer Screening \& Surveillance database?

Circle the number

0

12

3

4

5 


\section{Appendix G}

\section{Nursing Documentation Chart Audit}

\begin{tabular}{|c|c|c|c|c|c|c|}
\hline \multirow[t]{2}{*}{$\begin{array}{c}\text { Date } \& \text { Time of } \\
\text { Visit }\end{array}$} & \multirow[t]{2}{*}{ Clinic Name } & \multirow[t]{2}{*}{$\begin{array}{l}\text { Initials of Nurse } \\
\text { Who Saw the Patient }\end{array}$} & $\begin{array}{c}\text { Type of CRCS Due } \\
\text { (F= FIT; C=colonoscopy; } \\
\text { O=other (specify) }\end{array}$ & $\begin{array}{c}\text { Documentation in EHR about } \\
\text { CRCS patient counseling? } \\
\text { (Y=yes; N=no) }\end{array}$ & \multirow[t]{2}{*}{ Auditor Initials } & \multirow[t]{2}{*}{ Date of Audit } \\
\hline & & & $\begin{array}{l}\text { [ ] F } \quad[\text { ] C } \\
\text { Other (specify): }\end{array}$ & [ ] $\mathrm{N}$ & & \\
\hline & & & \begin{tabular}{|ll} 
[ ] F & [ ] C \\
Other (specify): &
\end{tabular} & $\begin{array}{llll} & \mathrm{Y} & \mathrm{Y}\end{array}$ & & \\
\hline & & & $\begin{array}{l}{[\text { ] ] F }} \\
\text { Other (specify): }\end{array}$ & [ ] $\mathrm{N}$ & & \\
\hline & & & $\begin{array}{ll}\text { [ ] F F } & \text { [ ] C } \\
\text { Other (specify): }\end{array}$ & [ ] $\mathrm{N}$ & & \\
\hline & & & $\begin{array}{cc}\text { [ ] F } & \text { [ ] C } \\
\text { Other (specify): } & \end{array}$ & [ ] $\mathrm{N}$ & & \\
\hline & & & $\begin{array}{ll}\text { [ ] F } & \text { [ ] C } \\
\text { Other (specify): } & \end{array}$ & [ ] $\mathrm{N}$ & & \\
\hline & & & $\begin{array}{cc}\text { [ ] F F } & \text { [ ] C } \\
\text { Other (specify): } & \end{array}$ & [ ] $\mathrm{N}$ & & \\
\hline
\end{tabular}




\section{Appendix H}

\section{Standard Work for CRCS in Primary Care}

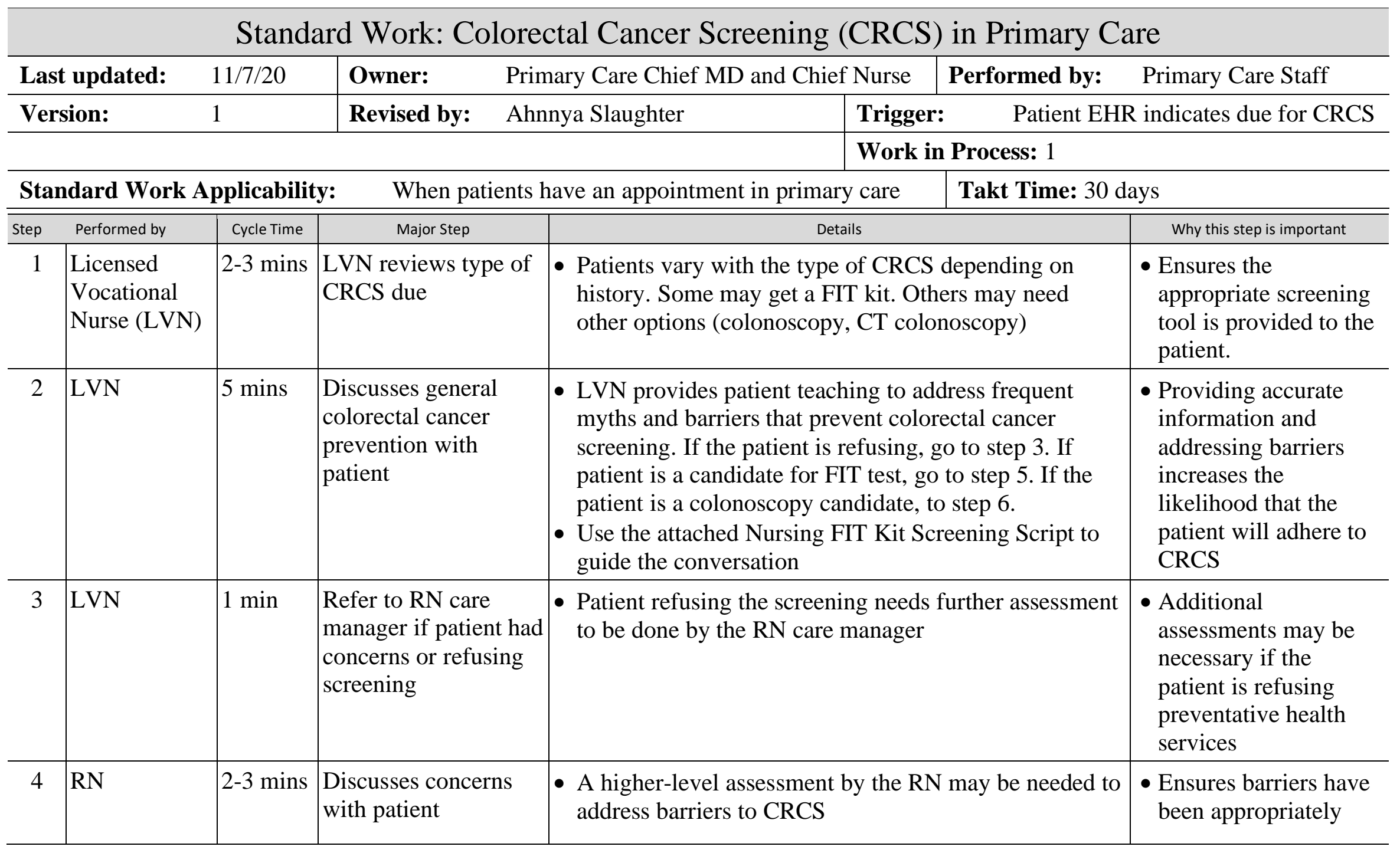




\begin{tabular}{|c|c|c|c|c|c|}
\hline Step & Performed by & Cycle Time & Major Step & Details & Why this step is important \\
\hline & & & & $\begin{array}{l}\text { - If patient agrees, go to step 5. If patient does not agree, } \\
\text { go to step } 6\end{array}$ & $\begin{array}{l}\text { addressed and that the } \\
\text { patient understands } \\
\text { the risks of their } \\
\text { decision }\end{array}$ \\
\hline 5 & RN/LVN & $5 \mathrm{~min}$ & $\begin{array}{l}\text { Provide FIT kit for } \\
\text { FIT-eligible patients } \\
\text { per clinical reminder }\end{array}$ & $\begin{array}{l}\text { - Provide FIT kit instructions including caution about } \\
\text { FIT kit expiration date and process for returning } \\
\text { - Verify understanding by using the Teach-Back method }\end{array}$ & $\begin{array}{l}\text { - Patient teaching } \\
\text { ensures likelihood that } \\
\text { the process is done } \\
\text { correctly } \\
\text { - Teach-Back method } \\
\text { verifies the patient } \\
\text { understood the } \\
\text { instructions } \\
\text { - Teach-Back method } \\
\text { verifies the patient } \\
\text { understood the } \\
\text { instructions }\end{array}$ \\
\hline 7 & RN & 2-3 mins & Document in EHR & - Document patient's decision in the EHR & $\begin{array}{l}\text { - Ensures information is } \\
\text { available in the EHR } \\
\text { for all clinicians } \\
\text { involved in the care } \\
\text { - Documentation is } \\
\text { critical from a }\end{array}$ \\
\hline
\end{tabular}




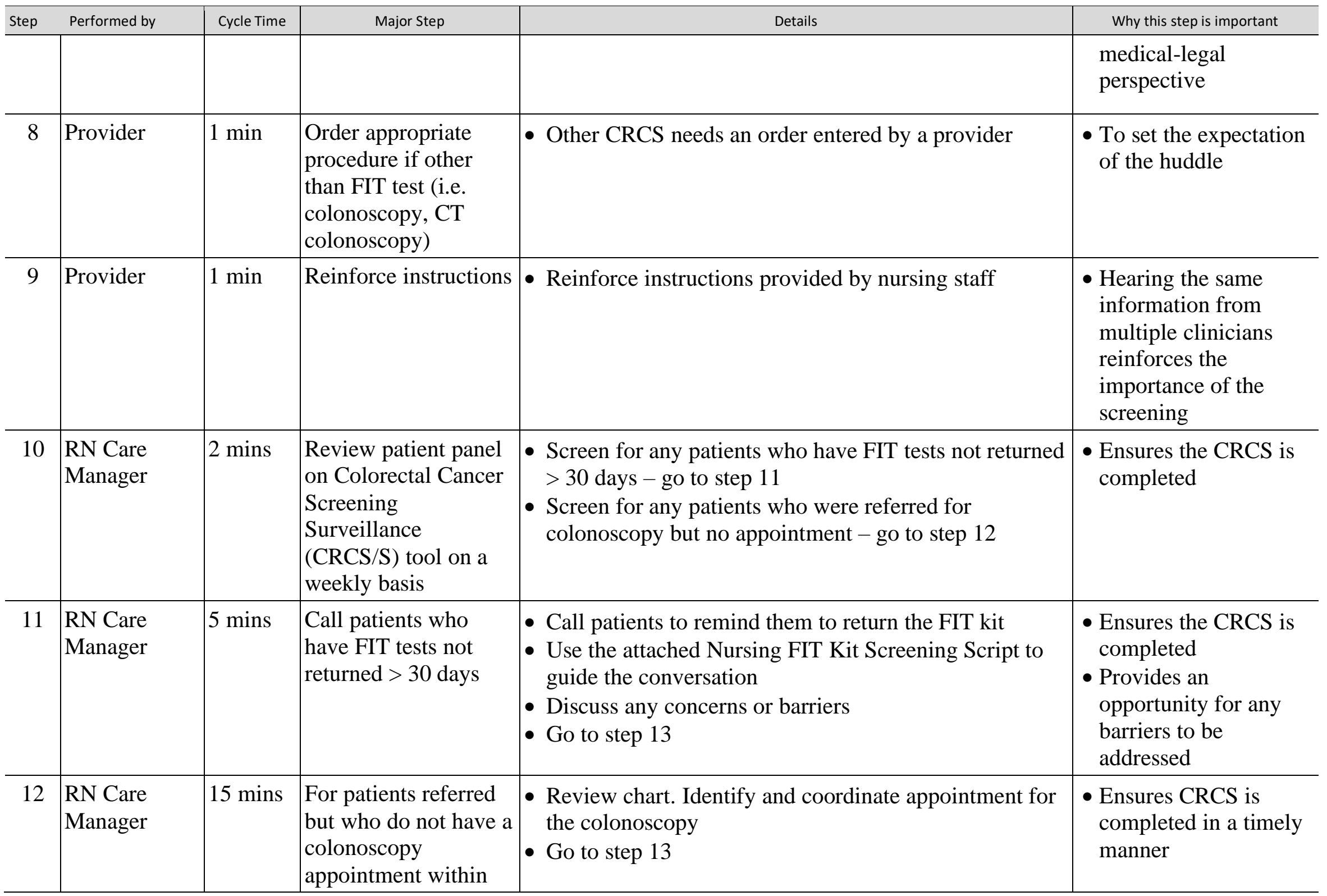




\begin{tabular}{|c|c|c|c|c|c|}
\hline Step & Performed by & Cycle Time & Major Step & Details & Why this step is important \\
\hline & & & $\begin{array}{l}30 \text { days, review chart } \\
\text { and take appropriate } \\
\text { action }\end{array}$ & & \\
\hline 14 & $\begin{array}{l}\text { RN Care } \\
\text { Manager }\end{array}$ & 5 mins & $\begin{array}{l}\text { Repeat process from } \\
\text { step } 10 \text { at } 60 \text { days and } \\
90 \text { days for any } \\
\text { patients with } \\
\text { incomplete CRS }\end{array}$ & $\begin{array}{l}\text { - Continue to track until CRCS is completed } \\
\text { - Take appropriate action to coordinate care } \\
\text { - If not able to resolve at own level, escalate to lead RN } \\
\text { care manager for guidance }\end{array}$ & $\begin{array}{l}\text { Discuss how these } \\
\text { metrics align with the } \\
\text { department and } \\
\text { facility's strategic } \\
\text { direction }\end{array}$ \\
\hline 15 & $\begin{array}{l}\text { RN Care } \\
\text { Manager }\end{array}$ & 2 mins & $\begin{array}{l}\text { After } 90 \text { days, } \\
\text { escalate case to lead } \\
\text { RN Care Manager }\end{array}$ & - After 90 days, escalate case to lead $\mathrm{RN}$ care manager & $\begin{array}{l}\text { - Ensures complex } \\
\text { patients are referred to } \\
\text { a more experienced } \\
\text { clinician }\end{array}$ \\
\hline$*$ & $\begin{array}{l}\text { Additional } \\
\text { Resources }\end{array}$ & N/A & Resources for patients & $\begin{array}{l}\text { - Patient Health Library - Colorectal Cancer } \\
\text { https://www.veteranshealthlibrary.va.gov/RelatedItems } \\
\text { /142,87081_VA } \\
\text { - Lots of resources for patients: } \\
\text { https://vaww.prevention.va.gov/docs/Colorectal_Cance } \\
\text { r_Resource_Document.pdf (must be within healthcare } \\
\text { system network to access) } \\
\text { - VIP - Integrated Education Program (link accessible } \\
\text { within healthcare system) }\end{array}$ & $\begin{array}{l}\text { - Provide patient with } \\
\text { resources consistent } \\
\text { with preferred } \\
\text { learning style }\end{array}$ \\
\hline
\end{tabular}




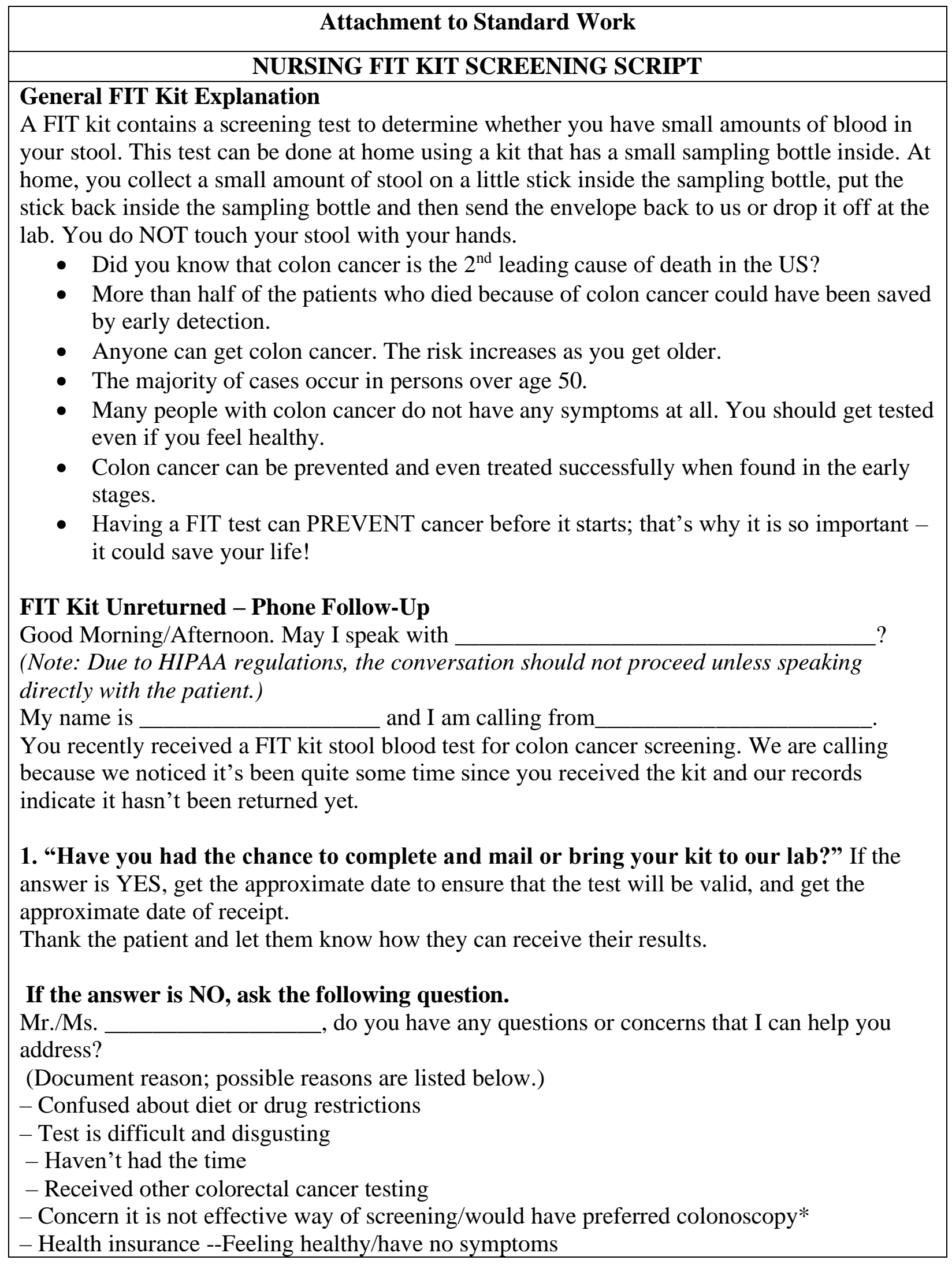




\section{Emphasize the benefits of screening.}

"Colon cancer can affect anyone - men and women alike - and your risk increases with age. It is one of the most common cancers in the U.S. There are often no symptoms of early stage colon cancer, but it can be detected early or even prevented through screening. That's why it's so important for you to return your test. The American Cancer Society recommends stool testing as one of many options, as an effective way to screen for colon cancer, and we know it can save lives. Many people appreciate that it is an easy test they can do at home. [Explain how to return test].

\section{Do you have any other questions?}

4. When do you think you can complete the test?

Document when patient commits to completing the test

Note: Adapted from: Evidence-Based Cancer Control Programs. (2014, August 26). Healthy colon, healthy life: Telephone counseling script. https://ebccp.cancercontrol.cancer.gov and U.S. Department of Veterans Affairs. (2020e, November 13). Are you FIT?

https://www.prevention.va.gov 